UNIVERSIDADE DE SÃO PAULO

ESCOLA DE ENFERMAGEM

EDENIR APARECIDA SARTORELLI TOMAZINI

DESENVOLVIMENTO E AVALIAÇÃO DE CURSO ON-LINE SOBRE SUPORTE AVANÇADO DE VIDA EM PARADA

CARDIORRESPIRATÓRIA PARA ENFERMEIRO

São Paulo

2017 



\section{DESENVOLVIMENTO E AVALIAÇÃO DE CURSO ON-LINE SOBRE SUPORTE AVANÇADO DE VIDA EM PARADA CARDIORRESPIRATÓRIA PARA ENFERMEIRO}

Dissertação apresentada ao Programa de Pós-Graduação em Gerenciamento em Enfermagem da Escola de Enfermagem da Universidade de São Paulo para obtenção do título de Mestre em Ciências.

Área de Concentração: Fundamentos e Práticas de Gerenciamento em Enfermagem e em Saúde.

Orientadora: Prof. ${ }^{a}$ Dr. ${ }^{a}$ Heloisa Helena Ciqueto Peres.

São Paulo

2017 
Assinatura:

Data:

\section{Catalogação na Publicação (CIP) \\ Biblioteca "Wanda de Aguiar Horta" \\ Escola de Enfermagem da Universidade de São Paulo}

Tomazini, Edenir Aparecida Sartorelli

Desenvolvimento e avaliação de curso on-line sobre suporte avançado de vida em parada cardiorrespiratória para enfermeiro / Edenir Aparecida Sartorelli Tomazini. São Paulo, 2017.

$157 \mathrm{p}$.

Dissertação (Mestrado) - Escola de Enfermagem da Universidade de São Paulo.

Orientadora: Prof. ${ }^{a}$ Dr. ${ }^{a}$ Heloisa Helena Ciqueto Peres

Área de concentração: Fundamentos e Práticas de Gerenciamento em Enfermagem e em Saúde

1. Tecnologia educacional. 2. Educação à distância. 3. Avaliação de curso. 4. Ressuscitação. 5. Parada cardíaca. 6. Educação permanente. 7. Informática em Enfermagem. I. Título. 
Nome: Edenir Aparecida Sartorelli Tomazini

Título: Desenvolvimento e Avaliação de Curso on-line sobre Suporte Avançado de Vida em Parada Cardiorrespiratória para Enfermeiro.

Dissertação apresentada ao Programa de Pós-Graduação em Gerenciamento em Enfermagem da Escola de Enfermagem da Universidade de São Paulo para o título de Mestre em Ciências.

Aprovado em:

BANCA EXAMINADORA

Orientador: Prof. Dr.

Instituição:

Assinatura:

Prof. Dr. Instituição:

Julgamento: Assinatura:

Prof. Dr. Instituição:

Julgamento: Assinatura:

Prof. Dr. Instituição:

Julgamento: Assinatura: 



\section{DEDICATÓRIA}

À minha mãe, Carlota, minha melhor amiga e, por vezes, filha. Mulher valorosa, exemplo de pessoa,

humildade e fé, que soube me educar com muita serenidade e amor e, mesmo diante de sua simplicidade, sempre valorizou meus estudos e se esforçou para que meus sonhos se realizassem.

Ao meu pai Osvaldo, a quem também devo honras de minha educação, valores, cidadania, responsabilidade e plenitude e, mesmo do seu jeito, por sempre acreditar em mim.

Aos meus filhos Ana Luiza e Márcio Vinicius, representação do amor de DEVS em minha vida. Vocês são meus verdadeiros mestres ao me ensinarem ver e sentir o mundo por diferentes ângulos e serem minha força para enfrentar os desafios. Perdão pela minha ausência e pelos momentos de intolerância. Meu eterno agradecimento a vocês por contribuírem com a minha evolução pessoal, profissional e espiritual. Amo vocês infinitamente.

Ao meu esposo, companheiro e amigo, Luiz Carlos, por sempre acreditar em mim e compreender a minha ausência em todos os momentos em que negligenciei como mãe e esposa, por compartilhar comigo os detalhes de minha luta e de meus sonhos. Sua presença me transmite amor, paciência e serenidade.

À minha irmãa, amiga, cúmplice, meu exemplo de luta e perseverança, que me encoraja, mesmo que inconscientemente, quando eu penso que não vou conseguir e divide comigo os momentos de alegria, de dúvidas e de angústias. $\mathcal{E}$, em particular, por evidenciar a importância de viver o "Hoje" e o "Amor".

Ao Breno, meu sobrinho, que, na sua inocência de criança, me ensina o valor da responsabilidade, disciplina e amor incondicional.

Aos meus Familiares e Amigos, em especial, minha sogra, Nair, e meu sogro, Antonio, "in memoriam", pelas orações, vibrações, palavras de incentivo e coragem e por me acalentarem nos momentos de cansaço e preocupações. O vosso amor e carinho me fortaleceram para o alcance deste 



\section{AGRADECIMENTOS}

Aqui só há palavras, mas espero que elas expressem a minha gratidão genuína a todos que contribuíram para que este trabalho fosse realizado.

Ao DEUS Altíssimo! O SENFHOR escolheu as pessoas que estariam em meu caminho para me ajudar, porque sabia que, sozinha, sua serva, tão pequena e aprendiz, não conseguiria. Por isso, obrigada por $S \cup \mathcal{A}$ força e, principalmente, por me carregar em seu colo nos momentos de angústias e me fazer ir além do que eu jamais pensei alcançar.

À Professora Doutora Heloisa Helena Ciqueto Peres, pela oportunidade, confiança e paciência. Sou imensamente grata a você pela competência na condução e orientação deste estudo e, especialmente,

e por me acolher em seu coração e me ver como ser humano repleto de sentimentos, limites e potencialidades.

Às Professoras Doutoras Mildred Patrícia Ferreira da Costa, Claudia Prado e Maria Madalena Januário Leite, meu reconfecimento pelo carinho, amor, amizade e sabedoria, pelas valiosas contribuições no exame de qualificação e por me acompanharem nessa trajetória.

Às Professoras Doutoras Ariadne da Silva Fonseca e Maria Júlia Paes da Silva pelos ensinamentos e exemplos de competência, dignidade, respeito e humildade.

À Doutora Enfermeira Débora Cristina Alavarce, pela disponibilidade, paciência e apoio técnico na viabilidade do desenvolvimento deste trabalho e por me serenar em muitos momentos de ansiedade.

Às amigas, Lucia To6ase, Denise Maria de Almeida, Juscilynne Barros da Costa Aroldi, Maria Elisa da Diniz Nassar, Simone Valentim Teodoro, pelo exemplo de fé, determinação e ousadia para vencer. Minhas amigas, eterna gratidão pelo imensurável auxílio em todas as áreas, por oportunizarem momentos maravilhosos de aprendizado e serem meus Anjos diante das alegrias e angústias.

À Faculdade de Medicina da Vniversidade de São Paulo, especialmente à equipe da Telemedicina e Projeto Homem Virtual, pela elaboração e compartilhamento dos recursos educacionais em 3D. À Hipocampus, representada pela Doutora Enfermeira Débora Cristina Alavarce, pela parceria e relevante apoio no desenvolvimento dos recursos educacionais.

Aos enfermeiros que participaram da avaliação do curso on-line e pelas valiosas contribuições. Aos pesquisadores do Grupo de Estudos e Pesquisas de Tecnologias da Informação nos Processos de Trabalho em Enfermagem, por compartilharem amizades, esforços e conhecimentos para o desenvolvimento deste estudo. 

À Escola de Enfermagem da Universidade de São Paulo, pela oportunidade de aprendizado e crescimento em Enfermagem.

À Secretaria do Programa de Pós-Graduação em Enfermagem, pelo auxílio e orientação ao longo desta jornada.

Aos colaboradores da biblioteca pela atenção, orientações e ensinamentos e pela elaboração da ficha catalográfica.

Ao Serviço de Atendimento Móvel de Vrgências, da cidade de São Paulo, em especial à Enfermeira Denise Santos Vilela e aos colaboradores do Júcleo de Educação em Vrgência pelo incessante apoio e incentivo e por oportunizar preciosas conciliações na consecução deste intento.

À equipe do CELAAB, pela contribuição valiosa na concepção da pesquisa, em especial à atenção e carinho de Verônica Cunha Rodrigues de Oliveira e Marcos Antonio Vieira.

À equipe do Centro de Simulação Realística da Rede de Hospitais São Camilo de São Paulo, pela oportunidade e empenho na realização das imagens. Meu eterno carinho por essa "Casa" que me acolheu e ensinou os primeiros passos no âmbito da Emergência.

Às enfermeiras Karina, Andrea e Samira do Hospital Universitário, pelo auxílio na revisão do conteúdo e pelas valiosas sugestões.

Às enfermeiras Catarina e Gisele do COREN - SPEducação, pela amizade, troca de saberes e por compartilharem dos momentos alegres e estressantes dessa trajetória.

Ao Bernardo Pereira dos Santos, pelas orientações ao efetuar a análise estatística.

À Rejane Monteiro pela importante tarefa na revisão da língua portuguesa, e ao Marcello Pimentel na finalização deste trabalho e por me transmitir serenidade.

A minha amiga Juscilynne e ao Emanuel pelo carinho e atenção na tradução de inglês.

Aos amigos André, Rita de Cássia, Marcia, Cintya, Fernanda, Marcos, Roselma, Claudia, Cássio, pela colaboração em diferentes contextos e por se preocuparem comigo.

Por fim, a todos que, embora não citados, contribuíram na construção de minha história pessoale profissional.

Que 6om ter esse espaço para pedir: DEUS abençoe a cada um!!! 

Tomazini EAS. Desenvolvimento e avaliação de curso on-line sobre suporte avançado de vida em parada cardiorrespiratória para enfermeiro. [dissertação]. São Paulo: Escola de Enfermagem, Universidade de São Paulo; 2017.

\section{RESUMO}

Introdução: O desenvolvimento e a aplicação das Tecnologias de Informação e Comunicação associadas à internet exercem mudanças no processo de ensino aprendizagem e podem contribuir para a educação permanente em enfermagem, favorecendo a capacitação de enfermeiros, para reconhecer imediatamente a situação de parada cardiorrespiratória (PCR) de adultos e sistematizar as intervenções de suporte avançado de vida (SAV), a fim de que colaborem para o sucesso da reanimação cardiopulmonar e maior sobrevida dos pacientes. Objetivos: Desenvolver e avaliar a qualidade do curso on-line para enfermeiros sobre suporte avançado de vida nos casos de parada cardiorrespiratória em adultos. Método: Pesquisa metodológica aplicada, na modalidade de produção tecnológica de natureza quantitativa, exploratória e descritiva. Para o desenvolvimento do curso on-line, utilizou-se o modelo de Design Instrucional Contextualizado (DIC). A seleção dos participantes foi aleatória, intencional e não probabilística. Participaram do estudo dezesseis enfermeiros especialistas na área de urgência e emergência adultos e/ou de educação on-line. A coleta de dados ocorreu no período de novembro a dezembro de 2016. A avaliação do curso on-line foi baseada em critérios validados de Avaliação da Qualidade de Objetos de Aprendizagem. Resultados: O curso online foi implementado no ambiente virtual de aprendizagem (AVA) Moodle ${ }^{\circledR}$, em nove unidades de aprendizagem e obtiveram índices de alta e boa qualidade em quinze $(75 \%)$ critérios referentes à pertinência, contextualização, qualidade da informação, navegação, referências, portabilidade, correção de conteúdo, clareza das informações, facilidade de aprendizagem na interação e de localização das informações, interatividade, eficiência de utilização, utilização de recursos audiovisuais, ergonomia e estética. Foram avaliados cinco (25\%) critérios como qualidade mediana relacionados à facilidade de retorno, uso de marcas especiais, gestão de erros, múltiplas janelas, ajuda aos usuários. Conclusões: os resultados mostraram que os referenciais teórico-metodológicos e pedagógicos adotados possibilitaram o desenvolvimento do curso on-line sobre SAV em PCR de adultos conferindo-lhe viabilidade de integrar tecnologias e estratégias educacionais inovadoras na implementação de capacitação e atualização de enfermeiros nas situações de emergência utilizando AVA.

Palavras-chave: 1. Tecnologia educacional. 2. Educação à distância. 3. Avaliação de curso. 4. Ressuscitação. 5. Parada cardíaca. 6. Educação permanente. 7. Informática em enfermagem. 

Tomazini EAS. Development and evaluation of an on-line course on advanced life support in cardiorespiratory arrest for nurses. [dissertation] São Paulo: School of Nursing, University of São Paulo; 2017.

\begin{abstract}
Introduction: The development and application of Information and Communication Technologies associated to internet bring evidence-based changes in the processes of teaching and learning and may contribute for permanent education in nursing, promoting the training and the qualification of nurses on recognition of situations of cardiorespiratory arrest (CPR) in adults and on the systematization of advanced life-support interventions, in order to collaborate for the success of cardiopulmonary resuscitation and longer survival of adult patients.
\end{abstract} Objectives: Develop and evaluate the quality of the on-line course on advanced life support in adult cardiorespiratory arrest for nurses. Method: Applied methodological research, in the form of technological production based on quantitative, exploratory and descriptive research. For the development of the on-line course the Contextualized Instrumental Design (DIC) model was used. The selection of participants was random, intentional and non-probabilistic. Sixteen nurses specialists in the area of urgency and emergency to adult and/or on-line education participated in the study. Data collection has taken place from November to December 2016. The evaluation of the on-line course was based on assessed criteria of Learning Object Quality Assessment. Results: The on-line course was implemented in the Moodle ${ }^{\circledR}$ virtual learning environment in nine learning units and obtained high quality indexes in fifteen (75\%) criteria regarding pertinence, contextualization, information quality, navigation, references, portability, content correction, technical information, ease of learning in interaction and location of information, interactivity, efficiency of use, use of audiovisual resources, ergonomics and aesthetics. Five (25\%) criteria were evaluated a median quality related to ease of return, use of special brands, error management, multiple windows, and user assistance were also evaluated. Conclusions: The results showed that the theoretical, methodological and pedagogical frameworks adopted allowed the development of the on-line course on life-support interventions in adult CPR focused on adult learning, making it possible to integrate innovative educational technologies in the implementation of training and professional updating for nurses in the emergency situations using virtual learning environment.

Key words: 1. Educational technology. 2. Distance education. 3. Course evaluation. 4. Cardiopulmonary resuscitation 5. Cardiorespiratory arrest 6. Continuing education. 7. Computer science in nursing. 



\section{LISTA DE FIGURAS}

Figura 1 - Fases do Design Instrucional Contextualizado.

Figura 2 - Representação do delineamento metodológico da pesquisa.

Figura 3 - Algoritmo de Suporte Avançado de Vida em PCR no Adulto. 78

Figura 4 - Tela de identificação para acesso ao curso 79

Figura 5 - Tela inicial do curso. 79

Figura 6 - Rota de navegação nas unidades de aprendizagem. 80

Figura 7 - Tela inicial do curso com a Avaliação Diagnóstica. 81

Figura 8 - Modelo de questão da avaliação diagnóstica 82

Figura 9 - Tela com a apresentação dos temas das unidades de aprendizagem sugeridos para estudo de acordo com o resultado da avaliação diagnóstica.

Figura 10 - Vídeo sobre o Desfibrilador Externo Automático. 85

Figura 11 - Exemplo de hipertexto na mesma página. 86

Figura 12 - Exemplo de hipertexto com link a outra página. 86

Figura 13 - Vídeo sobre ECG do Projeto Homem Virtual. 87

Figura 14 - Feedback das respostas corretas. 88

Figura 15 - Feedback das respostas incorretas 88

Figura 16 - Imagem do jogo digital do tipo Nave referente a unidade de aprendizagem Causas Reversíveis de PCR.

Figura 17 - Imagem do jogo digital do tipo quebra-cabeça referente a unidade de aprendizagem Análise do Ritmo Cardíaco 90

Figura 18 - Tela de acesso à simulação virtual. 91

Figura 19 - Tela inicial da simulação virtual. 91

Figura 20 - Tela com apresentação do avatar. 92

Figura 21 - Telas representativas das questões e feedback da simulação virtual. 93 



\section{LISTA DE SIGLAS}

$3 \mathrm{D}$

Terceira Dimensão

ABNT Associação Brasileira de Normas Técnicas

ACE Atendimento Cardíaco de Emergência

ACLS Advanced Cardiovascular Life Support

ADDIE Analysis, Design, Development, Implementation and Evaluation

AHA American Heart Association

AKUE Analyse, Konzeption, Umsetzung and Evaluation

APH Atendimento Pré - Hospitalar

AVA Ambiente Virtual de Aprendizagem

BIG Bone Injection Gun

CAAE Certificado de Apresentação para Apreciação Ética

CELAB Centro dos Laboratórios de Enfermagem em Ensino, Habilidades, Simulação e Pesquisa

CEP Comitê de Ética e Pesquisa

CETENF Centro de Estudos em Tele-enfermagem

CNPq Conselho Nacional de Desenvolvimento Científico e Pesquisa

DEA Desfibrilador Externo Automático

DI Design Instrucional

DIC Design Instrucional Contextualizado

DP Desvio Padrão

ECG Eletrocardiograma

EEUSP Escola de Enfermagem da Universidade de São Paulo

EPS Educação Permanente em Saúde

ERC European Resuscitation Council

FMUSP Faculdade de Medicina da Universidade de São Paulo

FV Fibrilação Ventricular

GEPETE Grupo de Estudos e Pesquisas de Tecnologias da Informação nos Processos de Trabalho em Enfermagem

GNU General Public License 

HCFMUSP Hospital das Clínicas da Faculdade de Medicina da Universidade de São Paulo

IEC International Eletrotechnical Commission

ILCOR International Liaison Committee on Resuscitation

IPATRE Instituto Paulista de Treinamento e Ensino

ISO International Organization for Standartization

MOODLE Modular Object-Oriented Dynamic Learning Environment

NBR Norma Brasileira

NEU Núcleo de Educação em Urgência

OA Objeto de Aprendizagem

PCR Parada Cardiorrespiratória

PUC-RJ Pontifícia Universidade Católica do Rio de Janeiro

RCE Retorno da Circulação Espontânea

RCP Reanimação Cardiopulmonar

SAMU Serviço de Atendimento Móvel de Urgência

SAV Suporte Avançado de Vida

SBV Suporte Básico de Vida

SE Software Educacional

SP São Paulo

SPSS Statistical Package for the Social Sciences

SUS Sistema Único de Saúde

TAS Teoria da Aprendizagem Significativa

TCLE Termo de Consentimento Livre e Esclarecido

TIC Tecnologias da Informação e Comunicação

TVSP Taquicardia Ventricular Sem Pulso

USP Universidade de São Paulo 



\section{SUMÁRIO}

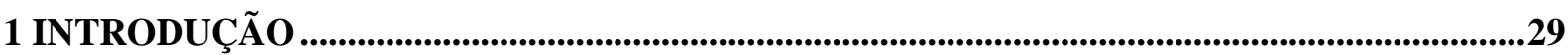

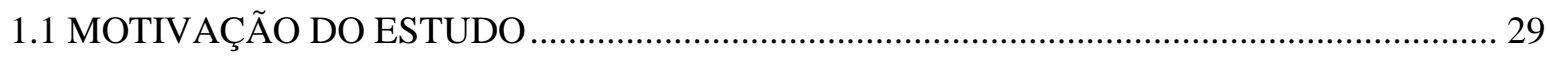

1.2 SUPORTE AVANÇADO DE VIDA E A EDUCAÇÃO PERMANENTE EM SAÚDE E

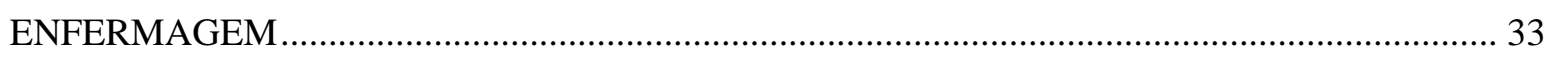

1.3 EDUCAÇÃO PERMANENTE E A EDUCAÇÃO ON-LINE EM ENFERMAGEM ................ 37

1.4 EDUCAÇÃO ON-LINE E AS PERSPECTIVAS PEDAGÓGICAS …..................................... 42

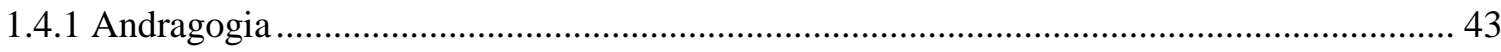

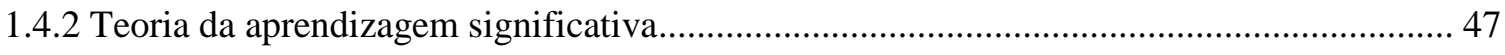

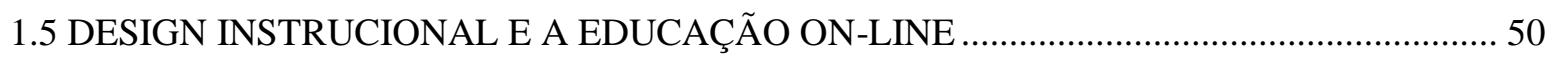

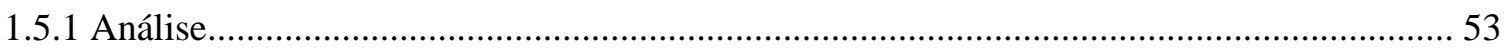

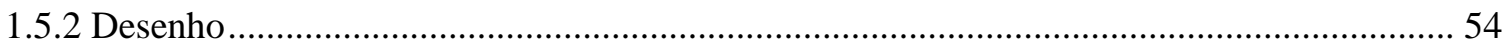

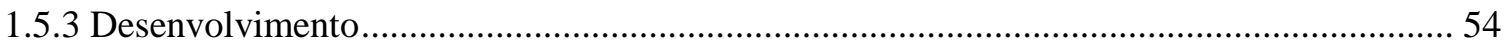

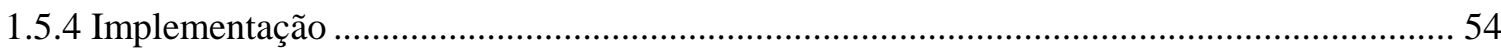

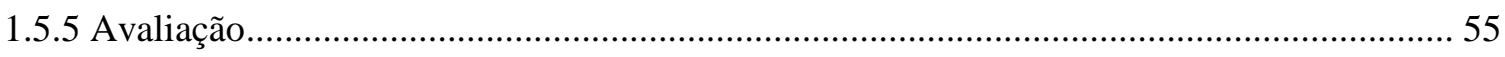

2 OBJETIVOS

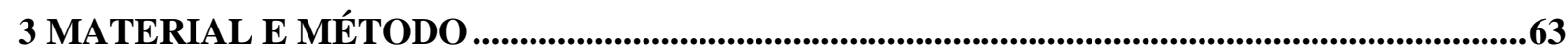

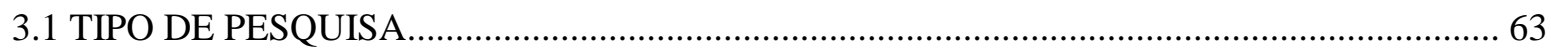

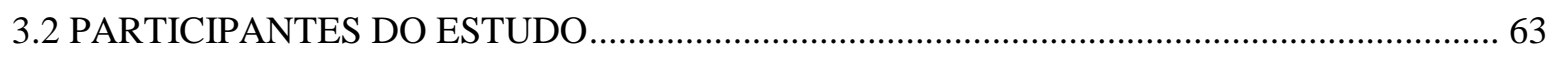

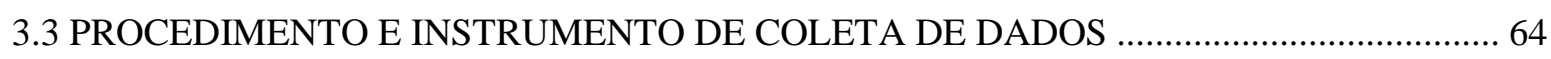

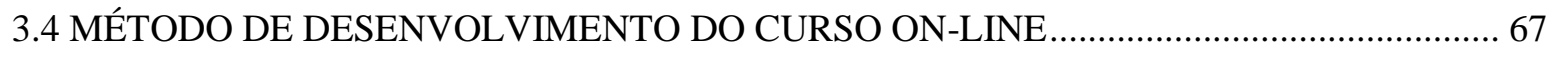

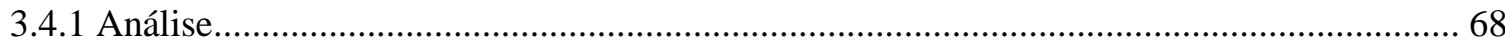

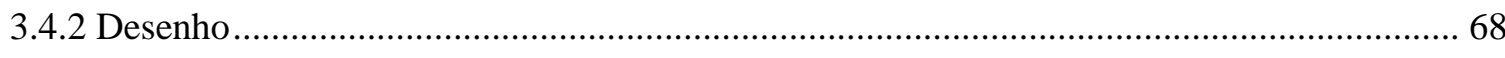

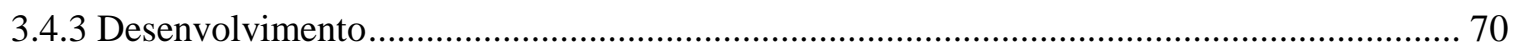

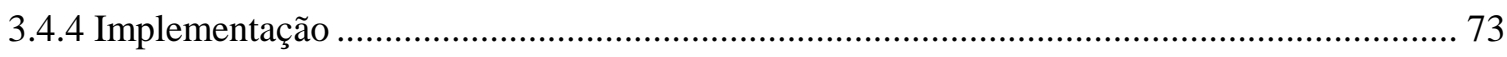

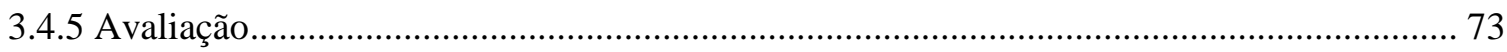





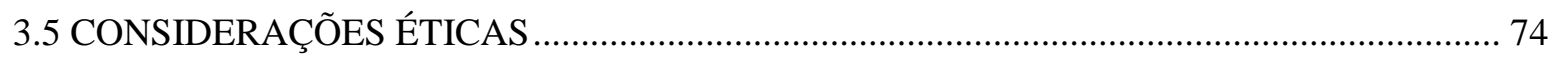

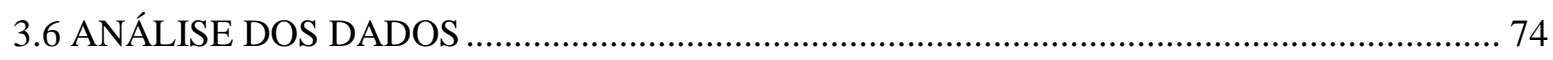

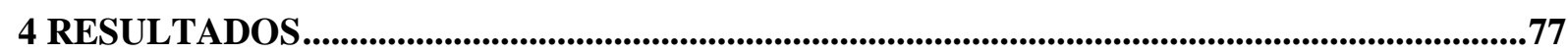

4.1 CURSO ON-LINE SOBRE SUPORTE AVANÇADO DE VIDA EM PARADA

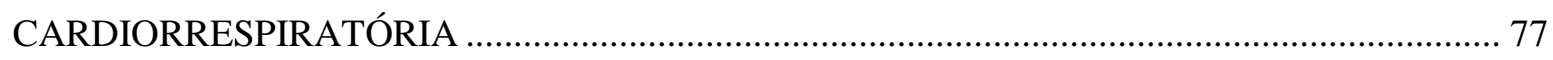

4.2 AVALIAÇÃO DA QUALIDADE DO CURSO ON-LINE NA PERSPECTIVA DE

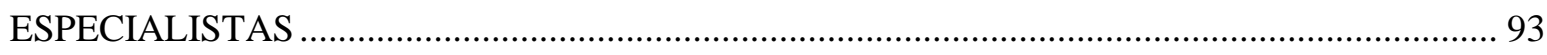

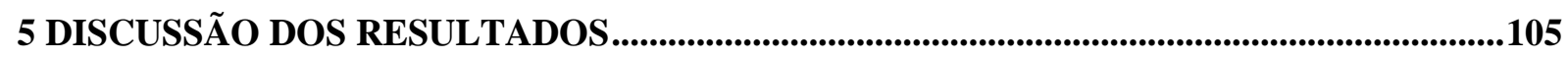

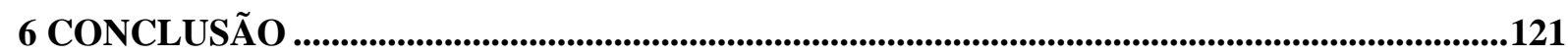

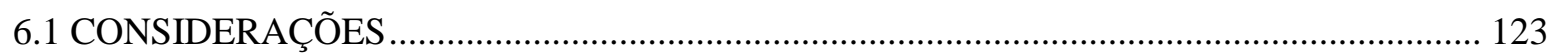

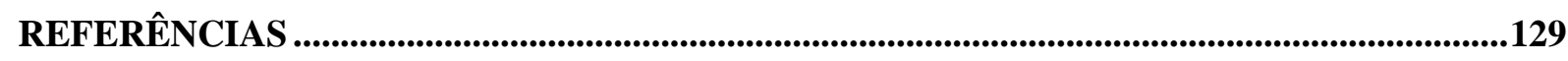

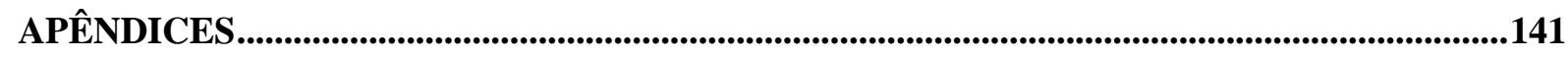

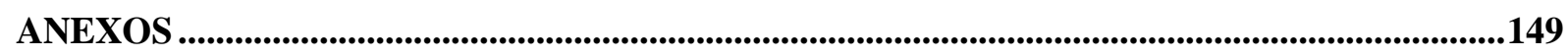



1 INTRODUCÃO 



\section{INTRODUÇÃO}

\subsection{MOTIVAÇÃO DO ESTUDO}

Durante minha trajetória profissional de dezoito anos, estive sempre a frente de situações de emergência que requerem raciocínio e ações ágeis e precisas, tanto no contex to da assistência quanto da educação. Minha primeira experiência foi em unidade de clínica médicocirúrgica, com predominância de pacientes pós-cirúrgicos de revascularização do miocárdio, onde emergiu a afinidade pela especialidade de cardiologia e cuidados intensivos. Observada a importância de ampliar os conhecimentos teórico-práticos para atuação nas situações de maior complexidade, com competência e qualidade, realizei em 1997, o curso de aprimoramento em terapia intensiva no Hospital das Clínicas da Faculdade de Medicina da Universidade de São Paulo (HCFMUSP).

A oportunidade de estagiar nas diferentes especialidades das unidades de terapia intensiva do HCFMUSP agregou muito conhecimento e me inspirou atuar com mais ênfase no cuidado ao paciente crítico.

Essa vivência também confirmou minhas impressões iniciais de que, ao atuar em unidade crítica de saúde, o profissional de enfermagem deve demonstrar conhecimento e habilidade para estabelecer prioridades e intervir de maneira consciente e segura no atendimento ao ser humano.

Em 1998, ao término do curso de aprimoramento desejava colocar meus conhecimentos em prática e então participei do processo seletivo para a unidade de terapia intensiva de um hospital particular da cidade de São Paulo. Uma vez aprovada, a vaga oferecida foi para o pronto socorro adulto. Aceitei o desafio, atuando por quatro anos como enfermeira assistencial e, então, fui promovida a chefe do departamento na qual permaneci por mais seis anos.

Em 2008, desliguei-me da instituição em decorrência da posse para o cargo de enfermeira intervencionista do Serviço de Atendimento Móvel de Urgência (SAMU 192) da cidade de São Paulo (SP). Neste serviço, integrei a equipe de Suporte Básico de Vida (SBV) e Avançado (SAV) e, posteriormente, de instrutores do Núcleo de Educação em Urgência (NEU). 
Como instrutora no NEU, atuo há oito anos na educação permanente em Atendimento Pré-Hospitalar (APH) dos profissionais. Durante os cursos ministrados, observei a complexidade desse processo de aprendizagem e a dificuldade do profissional de enfermagem de assimilar e aplicar o conteúdo na prática, de modo sistematizado, referente ao atendimento de parada cardiorrespiratória (PCR) em adulto - demonstrada pela divergência nas atitudes e nas condutas tomadas na realização dos procedimentos técnicos.

No acompanhamento desses profissionais em atividade prática, por vezes, deparei com situações de PCR no atendimento, em que foram iniciadas as manobras de reanimação cardiopulmonar (RCP), seguida de transferência do paciente para hospitais, onde seus colaboradores davam continuidade na assistência à situação de PCR ou pós-PCR. Verifiquei, ainda, que, tanto no APH quanto no hospital, houve incoerência na realização das técnicas e na sequência das ações, insegurança das equipes e da liderança para tomada de decisão, déficit de conhecimento quanto investigação das causas e intervenções recomendadas para cada situação.

Concomitantemente, na minha experiência como docente de aulas teóricas e práticas em curso de especialização em enfermagem em emergência, também observei o despreparo do enfermeiro para atuar nessas situações, em razão da dificuldade na sistematização das ações e no estabelecimento de prioridades, na liderança do atendimento e no trabalho em equipe. Situações estas as quais os enfermeiros comportavam-se, eventualmente, inertes ou extremamente ansiosos diante da complexidade que envolve o cenário de atendimento à PCR.

Diante dessa vivência, é notável a existência de dúvidas relacionadas à atuação dos profissionais de saúde frente à PCR, bem como a necessidade de organizar e uniformizar o atendimento diante das frequentes atualizações e mudanças que ocorrem nas diretrizes do American Heart Association e protocolos institucionais.

Além desses fatores, observou-se também lacunas de conhecimentos dos enfermeiros para o atendimento de $\operatorname{PCR}^{(1,2,3)}$. A literatura mostra que os profissionais de saúde não desconhecem totalmente o assunto, mas apresentam dúvidas em relação a sequência de intervenções recomendadas para o atendimento de PCR no SAV.

A chance de sucesso e reversão da PCR aumenta em duas vezes, se houver uma pessoa treinada em SAV na equipe de atendimento ${ }^{(4)}$. Dessa maneira, evidencia a necessidade de cursos de capacitação para o aprimoramento do conhecimento dos enfermeiros e, consequentemente, melhor desempenho profissional. 
Nesse sentido, a educação permanente é o processo de ensino-aprendizagem no trabalho, em que o ensinar e o aprender se incorporam no cotidiano das organizações, das pessoas e do trabalho, baseada na aprendizagem significativa capaz de transformar a práxis profissional. Sendo assim, é relevante trazer novas concepções para as ações educacionais, sob olhar transformador, inovador, com associação do conhecimento teórico às experiências vivenciadas na práxis cotidiana do profissional, que possibilita o desenvolvimento de competências para novas demandas direcionadas às suas realidades ${ }^{(5)}$.

Os enfermeiros são os profissionais que atuam em áreas críticas e estão expostos a essas situações com maior frequência e são, dentro da equipe, os responsáveis para participar da assistência direta ao paciente crítico - considerando que a PCR consiste em situação de extrema gravidade, além do importante papel na liderança e na capacitação da equipe. Os enfermeiros possuem carga de trabalho extensa e ampla diversidade de atribuições no cotidiano, reservandose tempo limitado para atualizações.

Os enfermeiros fazem parte da equipe de enfermagem que são frequentemente os primeiros a se depararem com a situação de PCR, e, portanto, o enfermeiro como líder de sua equipe, precisa agir com eficiência e rapidez nas manobras de RCP, conforme as recomendações estabelecidas pelas diretrizes internacionais e protocolos institucionais para liderar o atendimento, minimamente, até a chegada do médico.

Nessa perspectiva, compreende-se que a educação permanente propõe ao profissional o desenvolvimento de prática consciente e responsável, fundamentada no autoconhecimento, no aperfeiçoamento e na atualização, os quais promovem o aumento da competência e da valorização pessoal e profissional, bem como a contribuição para a melhoria da assistência prestada ao cliente, à comunidade e às instituições onde atuam.

Nesse percurso, pude ampliar a visão sobre o sistema educacional e a incorporação de novas metodologias integradas às inovações tecnológicas para o ensino, despertando, então, o interesse em aprofundar os conhecimentos nas áreas de educação e tecnologia.

Em 2010, passei a frequentar o Grupo de Estudos e Pesquisas de Tecnologia da Informação nos Processos de Trabalho da Enfermagem (GEPETE), vinculado ao Centro de Estudos em Tele-enfermagem da Escola de Enfermagem da Universidade de São Paulo (CETENF/EEUSP). Cabe ressaltar que o GEPETE compreende a união dos Grupos de Pesquisa: "Avaliação das práticas do ensino e da assistência à saúde" e "Tecnologia da 
informação nas diferentes dimensões do processo de trabalho em saúde: assistência, gerência, ensino e investigação" vinculados ao Conselho Nacional de Desenvolvimento Científico e Tecnológico $(\mathrm{CNPq})$.

Esse grupo, ao qual esta pesquisa está vinculada, tem o objetivo de integrar pesquisadores, alunos de pós-graduação e graduação nas áreas de Tecnologia da Informação e Comunicação em Saúde e Enfermagem, Tele-enfermagem e de Educação em Saúde e em Enfermagem, visando o desenvolvimento da incorporação de avanços tecnológicos na gerência, no ensino, na pesquisa e na assistência de enfermagem.

Nesse mesmo período de dedicação aos estudos e de aprimoramento no GEPETE, tive a oportunidade de planejar, desenvolver e implementar cursos de capacitação e de recertificação em APH para os profissionais que atuam no SAMU 192 SP.

Estes programas educacionais são estruturados fundamentados nos pressupostos da Andragogia e na Teoria da Aprendizagem Significativa (TAS) e, apoiados em estratégias de ensino ativas e críticas, como simulação de baixa, média e alta fidelidade, estudo de caso e oferecidos nas modalidades on-line, semi-presencial e presencial.

Cabe ressaltar que realizei cursos de "Capacitação de docentes no planejamento e desenvolvimento de cursos no ambiente virtual de aprendizagem", "Roteirização e produção de videoaulas para educação a distância" e "Docência e mediação pedagógica para educação a distância", com o intuito de proporcionar maior fundamentação teórica e vivência prática para o planejamento e o desenvolvimento de programas educacionais on-line.

Mediante essas experiências, atreladas às discussões e às reflexões realizadas no GEPETE, me aproximei de diferentes tecnologias aplicadas no ensino e na assistência, sendo possível vislumbrar a possibilidade de construir a proposta de curso on-line para enfermeiros sobre atendimento de SAV em PCR.

Destaca-se, ainda, que o Suporte Avançado de Vida no Atendimento do Adulto em Parada Cardiorrespiratória foi selecionado como temática do curso on-line diante das evidências da literatura que referenciam as doenças cardiovasculares como a primeira causa de óbito no cenário nacional e internacional - sendo a síndrome coronariana a principal responsável pelas PCR com potencial de reversão. 
E, nesta conjuntura, ingressei no Mestrado Acadêmico da Escola de Enfermagem da Universidade de São Paulo (USP) com a missão pessoal e profissional de mergulhar em novos saberes, multiplicar experiências e desenvolver curso on-line que possa contribuir para a educação permanente na área de emergência.

Diante do exposto e - acreditando que o curso on-line pode contribuir para a capacitação teórica e recertificação de enfermeiro, que atua no âmbito hospitalar, para reconhecer imediatamente a situação de PCR, priorizar e sistematizar os cuidados específicos na RCP e pós-PCR, a fim de colaborarem para o sucesso da reanimação e maior sobrevida dos pacientes - o presente estudo teve como finalidade a construção e a avaliação da qualidade de curso online sobre Suporte Avançado de Vida em PCR de adulto para enfermeiros.

\subsection{SUPORTE AVANÇADO DE VIDA E A EDUCAÇÃO PERMANENTE EM SAÚDE E ENFERMAGEM}

No cenário mundial, as doenças cardiovasculares respondem pela primeira causa de morte. Estima-se que 17,5 milhões de pessoas morreram de doenças cardiovasculares em 2012, representando $31 \%$ de todos os óbitos globais. Desses, aproximadamente 7,4 milhões ocorreram devido a doenças coronarianas ${ }^{(6)}$.

No Brasil, o perfil epidemiológico mostra que os agravos são predominantes em pessoas acima dos $40 \operatorname{anos}^{(7)}$, no que se refere à morbimortalidade por doenças cardio e cerebrovasculares.

A implementação de intervenções governamentais, sociais e individuais para a prevenção e controle de doenças cardiovasculares são fundamentais para reduzir esses números.

No entanto, mesmo com a efetivação dessas ações, alguns eventos não poderão ser evitados e evoluem para a situação de emergência mais grave - a parada cardiorrespiratória (PCR) - tendo como principal causa a doença arterial coronariana, que requer medidas imediatas e integradas para controle e tratamento. 
A parada cardiorrespiratória pode ser definida como a ausência de atividade mecânica cardíaca, confirmada por pulso carotídeo não detectável e apneia ou respiração agônica em pessoas não responsivas ${ }^{(8)}$.

Frente a essas condições, observam-se avanços importantes na atenção e tratamento no âmbito da saúde, com ênfase no atendimento à PCR.

Entretanto, apesar da evolução e de estudos contínuos sobre os agravos cardiológicos, reconhecidos como principal causa de morte, admite-se que a assistência ainda é falha, sendo necessárias novas ações para mudar esse cenário, como o estabelecimento e a disseminação de diretrizes sobre as manobras de RCP para as pessoas envolvidas no contexto, sejam elas profissionais da área da saúde ou leigos.

Com esse propósito, o International Liaison Committee on Resuscitation (ILCOR), entidade que congrega as principais organizações da área no mundo, reúne especialistas de diversas organizações internacionais para discussão, elaboração e padronização de diretrizes baseadas em estudos e evidências científicas que norteiam e sistematizam as intervenções, com objetivo de aumentar as chances de sobrevivência de pessoas em PCR. Em 2015, foram publicadas as diretrizes que vigoram no período de 2015-2020, em associação com várias entidades internacionais, como a American Heart Association - Associação Americana de Cardiologia (AHA) e o European Resuscitation Council - Conselho Europeu de Ressuscitação (ERC), com revisões previstas a cada cinco anos.

No Brasil, o Ministério da Saúde ${ }^{(9)}$ instituiu, por meio da portaria de No 1.600 de 2011, a Rede de Atenção às Urgências no Sistema Único de Saúde (SUS) com o intuito de otimizar as ações dos serviços de saúde e prover a atenção qualificada, integrada e hierarquizada à saúde de toda população brasileira com atendimento ágil e resolutivo das urgências e emergências, incluindo as situações de PCR.

Essa portaria visa à discussão e à implementação do sistema de atenção integral às urgências e inclui a qualificação da assistência por meio da educação permanente das equipes de saúde do SUS, em acordo com os princípios da integralidade e de humanização ${ }^{(10,11)}$.

O Ministério da Saúde ${ }^{(12)}$ descreve que a formação e a educação continuada dos profissionais para o enfrentamento às urgências ainda é deficitária, em virtude da fragmentação e hierarquização decorrente do ensino tradicional e da superficialidade dos conteúdos 
curriculares das instituições formadoras, o que resulta no comprometimento da qualidade e da resolutividade na assistência.

No âmbito da formação, apesar das escolas de enfermagem incluírem em seus currículos conteúdos relacionados ao atendimento de urgência e emergência em doenças cardiovasculares, a experiência tem evidenciado que a maior parte dos enfermeiros recém-formados não se sente capacitada, efetivamente, para atuar em situações de emergência - principalmente em casos de PCR, que exigem atendimento ágil e preciso do profissional para prevenir sequelas e morte ${ }^{(13)}$. Ainda que não desconheçam totalmente o assunto, apresentam dúvidas em relação à sequência do atendimento e à técnica adequada na realização das intervenções de SAV em PCR.

A PCR em ambiente intra-hospitalar apresenta, na maioria dos casos, ritmo inicial de atividade elétrica sem pulso (37\%) e Assistolia (39\%). Os ritmos de fibrilação ventricular e taquicardia ventricular sem pulso (FV/TVSP) são responsáveis por $20 \%$ a $24 \%$ dos eventos, no entanto, apresentando as maiores taxas de sobrevida, $36 \%$ a $37 \%$. A sobrevida geral é de $15 \%$ a $18 \%$, considerando todos os ritmos de PCR, sendo que $80 \%$ desses sobreviventes apresentavam status neurológico favorável até a alta hospitalar ${ }^{(14,15,16,17)}$.

O sucesso na reversão de PCR e na maior sobrevida hospitalar depende de diversos fatores como: condições clínicas do paciente antes da PCR, causas que determinaram a PCR, presença de função normal do ventrículo esquerdo antes do evento, local onde acontece o evento, dias da semana, período diurno, eventos presenciados, idade menor de 65 anos, tempo entre o incidente e o início das manobras de reanimação cardiopulmonar, duração do evento, qualidade e agilidade dessas intervenções, assim como padronização, sistematização e eficácia das manobras de RCP envolvendo pessoas leigas e equipes de saúde ${ }^{(17,18)}$.

Os significativos avanços nas pesquisas referentes ao atendimento do paciente em PCR ressaltam que o sucesso dos esforços de reanimação depende, principalmente, do reconhecimento imediato da situação, seguido de tomada de decisão rápida e coerente dos profissionais envolvidos no atendimento ${ }^{(19)}$.

A utilização de protocolos para avaliação e reconhecimento imediatos da PCR e a sistematização das intervenções para o atendimento de suporte básico e avançado de vida em parada cardiorrespiratória (PCR) no adulto impactam diretamente na redução das taxas de óbitos e sequelas. Estes métodos melhoram a qualidade da assistência aos pacientes, 
minimizando o sofrimento e as complicações, além do tempo de internação, dos riscos de infecção, e, por conseguinte, dos gastos com o tratamento.

O suporte básico de vida (SBV) constitui a base para o atendimento em PCR e inclui o reconhecimento imediato do evento, a ativação do sistema ou da equipe de resposta de emergência, a execução precoce das manobras de RCP e a rápida desfibrilação ${ }^{(20)}$.

O suporte avançando de vida (SAV) inclui intervenções que, realizadas associadas às manobras de SBV, potencializam a probabilidade de retorno da circulação espontânea (RCE), como: análise do ritmo cardíaco, desfibrilação com equipamento manual, terapia medicamentosa, gerenciamento avançado das vias aéreas, monitoramento fisiológico com equipamentos e dispositivos e investigação e tratamento da causa de PCR. Após o RCE, a sobrevivência e o desfecho neurológico podem ser melhorados com o tratamento integrado pós$\mathrm{PCR}^{(21)}$.

Diante dessas considerações, entende-se a razão pela qual a implementação de ações permanentes de capacitação e desenvolvimento profissional na temática do atendimento em PCR tem sido amplamente defendida e recomendada pela comunidade científica.

As frequentes mudanças nos protocolos assistenciais para PCR e as atualizações tecnológicas exigem abordagens periódicas e recertificações para sanar possíveis lacunas relacionadas aos conhecimentos e às habilidades técnicas exigidas durante a sua assistência.

Destaca-se que, em 2015, foram publicadas no Consenso Científico do ILCOR sobre Suporte Avançado de Vida em Cardiologia (ACLS) novas recomendações internacionais da AHA para RCP e atendimento cardíaco de emergência (ACE) e as Diretrizes da Sociedade Brasileira de Cardiologia.

A participação de equipes treinadas e a uniformidade das manobras de RCP são habilidades diretamente relacionadas à atuação do enfermeiro enquanto profissional capacitado para treinar, instruir e desenvolver ações de planejamento e execução durante o atendimento da $\mathrm{PCR}^{(18)}$.

Desta maneira, justifica-se a importância desta pesquisa de desenvolvimento de curso on-line sobre SAV em PCR por envolver, sobretudo, profissionais enfermeiros que estão frequentemente expostos a estes eventos e necessitam de atualização constante para melhorar a prática assistencial. 


\subsection{EDUCAÇÃO PERMANENTE E A EDUCAÇÃO ON-LINE EM ENFERMAGEM}

Em todas as áreas do conhecimento, ações de capacitação e desenvolvimento dos profissionais para promoção de melhorias nos ambientes de trabalho são imprescindíveis.

No âmbito da saúde, em razão das transformações que emergem rapidamente e da multiplicação do volume de informações em curto prazo, vinculadas à necessidade de assegurar assistência de qualidade aos usuários, torna-se imperativo a busca constante por saberes e pela apropriação do conhecimento, os quais requerem discussão e reflexão quanto aos processos de ensino aprendizagem necessários à formação para o trabalho.

Na enfermagem, essas mudanças do mundo contemporâneo, também, resultam em grande desafio no intento por atualização contínua no ambiente de trabalho, que exige profissionais qualificados, capazes de prestarem assistência imediata e integral ao paciente.

A área da enfermagem, quando comparada a outras ciências, é recente, mas tem apresentado acelerada produção de conhecimento em quantidade e qualidade. Com isso, o estudante de enfermagem se depara com a árdua tarefa de reter grande quantidade de informações no curto período de formação profissional ${ }^{(22)}$. Diante desses aspectos, o enfermeiro requer atualização permanente durante a sua práxis profissional.

A Educação Permanente em Saúde (EPS) representa importante modificação na concepção e nas práticas de capacitação dos trabalhadores dos serviços de saúde e enfoca a incorporação do ensino e do aprendizado à vida cotidiana das organizações e às práticas sociais e laborais, no contexto real em que ocorrem. Aliada às mudanças nas estratégias educativas, a partir da prática como fonte de conhecimento e de problemas, a EPS conduz os profissionais para a reflexão da práxis e da construção do conhecimento de maneira colaborativa, minimizando a fragmentação disciplinar e ampliando os espaços educativos fora da aula e dentro das organizações, nas associações, nos clubes e nas ações comunitárias ${ }^{(5)}$.

Os programas de educação permanente demandam planejamento dinâmico, participativo, com objetivos definidos, capazes de promover interação multiprofissional e integração de diferentes saberes e que os conteúdos programáticos contemplem o cotidiano, a 
realidade e a evolução tecnológica ${ }^{(23)}$. E ainda possam contribuir para a capacitação profissional, agregando aptidões para a tomada de decisão, raciocínio clínico, comunicação, liderança e gestão, buscando atender diretamente as necessidades do trabalho, do setor, da organização e dos profissionais.

Destaca-se, ainda, a importância do planejamento do curso composto por subsistemas coordenados que funcionam como estrutura organizada e auxilia na resolução de problemas práticos da organização, formado por três elementos básicos: levantamento de necessidades, planejamento e avaliação, sendo acrescido da execução do curso, inserido nesse processo ${ }^{(24)}$. As etapas de levantamento de necessidades, planejamento e execução são habitualmente conhecidas e, portanto, mais facilmente aplicáveis, desde que compatíveis com os objetivos do programa, anteriormente delimitados, a fim de que o processo possa ser concebido e entregue em nível de abrangência congruente com as demandas educacionais e tecnológicas do mundo contemporâneo $^{(25)}$.

A associação entre tecnologia e educação se torna cada vez mais inerente à reestruturação do processo de ensino aprendizagem na sociedade atual e possibilita que os novos meios digitais de se obter o acesso à informação e ao conhecimento se modifiquem e se aprimorem nos moldes da cultura globalizada $^{(26)}$. Nessa perspectiva, as Tecnologias da Informação e da Comunicação (TIC) apresentam ferramentas capazes de ampliar conceitos tradicionais de ensino, de espaço e de tempo.

Naturalmente, a inserção das TIC na educação requer transformação, desafiando professores e estudantes a novos processos, crenças e modos de relacionamento. Profissionais de saúde têm constatado na educação on-line possibilidades para atualização de maneira ativa, bem como as instituições de saúde que visualizam perspectivas de educação permanente com programas cíclicos de capacitação, desenvolvimento e treinamento de recursos humanos ${ }^{(27)}$.

O uso de tecnologia de maneira sistematizada e integrada às redes de comunicação interativa e aos hipertextos constitui-se como educação on-line, que vem sendo adotada como modalidade de ensino nas diferentes áreas do conhecimento e das ciências em saúde, para disseminação do conteúdo educacional e promoção da aprendizagem, sem limites de tempo ou de espaço e cuja característica principal é a mediação tecnológica pela conexão em rede ${ }^{(28,29)}$.

Os hipertextos são hiperdocumentos ou textos estruturados em rede de navegação rápida e intuitiva, com múltiplas janelas, constituídos por nós (palavras, páginas, imagens, vídeos, sons, 
textos, arquivos) e links entre os nós, indicando a passagem de um nó a outro e dando ao aprendiz o poder de mover-se entre diversas estruturas de informação de modo convergente e não-linear, assemelhando-se com o funcionamento da mente humana ${ }^{(30,31)}$.

A educação on-line pode ser compreendida como o conjunto de ações de ensino aprendizagem desenvolvidas por meio telemáticos, como a internet ${ }^{(29)}$, que objetiva favorecer o conhecimento aos aprendizes por meio de objetos de aprendizagem disponibilizados em diferentes formatos como software, vídeo e áudio, em Ambientes Virtuais de Aprendizagem (AVA).

O AVA consiste em programa que reúne soluções de comunicação, de gestão e de aprendizado via internet e possibilita o desenvolvimento e a integração de conteúdos no formato Web, a partir de experiências do mundo real ou virtual, produzidas ou adaptadas para propósitos educacionais $^{(32)}$.

Os AVA são espaços de multimídia na internet, que simulam a sala de aula presencial, de tal maneira que as ferramentas ou estratégias utilizadas no ambiente intencionam proporcionar o processo de ensino aprendizagem baseado na interação e na comunicação entre os próprios participantes e, esses com os educadores, incentivando o trabalho cooperativo e colaborativo $^{(28,33)}$.

Esses ambientes ${ }^{(32)}$ permitem integrar diferentes mídias em espaços virtuais de ensino, utilizando elementos de linguagem como o som, a imagem fixa, o vídeo e a escrita. Dentre essas, destacam-se aulas virtuais, objetos de aprendizagem, simuladores, fóruns, salas de batepapo, conexões a materiais externos, atividades interativas e jogos.

Essas especificidades tornam o AVA dinâmico, interativo e atual, mais próximo da realidade do usuário e extremamente rico, pois permite a utilização de diferentes recursos de mídia, além de impulsionar o processo de ensino aprendizagem mais criativo, interessante, poderoso e autônomo ${ }^{(34)}$.

Neste contexto, AVA configura-se como ponto de partida para novos desdobramentos no qual o professor deve tornar-se autor, coautor e eterno aprendiz, explorando as possibilidades desses artefatos para o desenvolvimento de uma prática plural, sintonizada com as demandas contemporâneas $^{(35)}$. 
O Moodle® - Modular Object-Oriented Dynamic Learning Environment é um AVA dinâmico, modular e orientado a objetos, caracterizado por software Open Sourse (aberto, livre e gratuito), de apoio aos processos de ensino e de aprendizagem, distribuído sob a General Public License (GNU), o que proporciona constante melhoria de suas funcionalidades. Software livre ou Free Software pode ser usado, copiado, estudado, modificado e redistribuído sem restrição ${ }^{(36)}$. Esse ambiente foi criado em 2001, pelo cientista da computação e professor Martin Dougiamas.

O software Moodle ${ }^{\circledR}$ configura-se como AVA que possibilita a interação, participação e cooperação dos aprendizes para a construção do conhecimento, a produção e o gerenciamento de atividades educacionais baseadas na internet $\mathrm{e} / \mathrm{ou}$ em redes locais ${ }^{(37)}$.

O Moodle ${ }^{\circledR}$ consiste em importante ferramenta de comunicação, que possibilita integrar e disseminar informações de maneira rápida, objetiva, dinâmica e gratuita, inclusive na rede de educação e saúde. E, por apresentar compatibilidade com diversos objetos de aprendizagem e estar disponível em vários idiomas, facilita a inclusão em diferentes projetos que envolve a educação e a tecnologia, como a educação permanente ${ }^{(38)}$.

No Moodle ${ }^{\circledR}$, diferentes recursos tais como livro, arquivo, página, rótulo, glossário, lição, questionário, pesquisa, tarefa, fórum, chat e a integração de objetos de aprendizagem podem favorecer a criação de atividades dinâmicas e que mobilizem o profisssional à aprendizagem.

Cabe destacar, ainda, os objetos de aprendizagem (OA), como outras possibilidades de recursos digitais educacionais, que podem veicular informações em diversos formatos como vídeos, imagens, ilustrações, hipertextos, páginas da web, apresentações de slides, jogos, simulações para auxiliar o ensino e a aprendizagem e estimular o desenvolvimento de capacidades pessoais como a criatividade e o raciocínio ${ }^{(39,40)}$.

A utilização de OA - compreendidos como recursos educacionais, em diversos formatos e linguagens ${ }^{(41)}$ - construídos em diferentes mídias e com objetivos específicos para as necessidades e peculiaridades da faixa etária em questão contribuem significativamente no processo de aprendizagem para o alcance dos objetivos propostos e potencializam as reflexões e a autocrítica ${ }^{(42,43)}$. 
Os OA possuem algumas características, que favorecem o uso principalmente na área educacional, como a flexibilidade, a reusabilidade, a atualização, a interoperabilidade e a portabilidade ${ }^{(44)}$, e são comumente disponibilizados por meio de links em AVA.

Dentre os tantos recursos tecnológicos digitais, os OA, no formato de exercícios interativos, jogos e simulações, têm sido cada vez mais aplicados na formação e no desenvolvimento profissional por propiciarem processos interativos e cooperativos de ensino e aprendizagem, que contribuem para a aquisição de novas competências e habilidades de comunicação e estimulam o raciocínio clínico e de tomada de decisão, o pensamento reflexivo, a criatividade, a autonomia e a autoria ${ }^{(40)}$ no enfrentamento dos problemas encontrados na vida real.

Os exercícios interativos, os jogos e os simuladores visam auxiliar na construção do saber e da autoconfiança e podem incrementar a motivação no contexto da aprendizagem no cuidado com a saúde, desde a prevenção ao enfrentamento das situações de emergência e ainda, reduzir custos com treinamento e desenvolvimento de recursos humanos ${ }^{(45)}$.

“O jogo ou game constitui-se em atividade lúdica composta por uma série de ações e decisões, limitada por regras e pelo universo do game, que resultam em condição final" (Schuytema, 2008, p.7) $^{(46)}$.

O caráter dinâmico e lúdico dos jogos propicia aos aprendizes a capacidade de pensar, de criar, de articular e de colocar em ação conhecimentos frente às situações que exijam capacidade propositiva, fortalecendo o desenvolvimento intelectual e profissional, autônomo e permanente $^{(47)}$.

Os jogos digitais propõem interação e desafios, colaboram com o desenvolvimento dos participantes e permitem melhor acessibilidade e contextualização dos conteúdos e integração de conceitos do tema abordado com o mundo real e, portanto, podem ser utilizados como objetos educacionais nos processos de formação e avaliação ${ }^{(48)}$. Nesses jogos, a abordagem pedagógica adotada utiliza a exploração livre e o lúdico e, como consequência, possibilita a expressão de sentimentos e de emoções e estimula o aprendiz na construção do conhecimento de comportamentos adequados e adaptativos.

Os jogos digitais educacionais oferecem nova abordagem na integração das tecnologias de ensino e dos conteúdos e são capazes de trazer benefícios, como melhorias no raciocínio lógico 
e de solução de problemas e permitir progressão lógica e apropriada para a absorção de novos conceitos $^{(45)}$.

A simulação consiste na representação dinâmica de determinados cenários, em várias dimensões, como um desenho animado, em que os parâmetros podem ser alterados facilmente e imediatamente visualizados os efeitos dessas modificações, podendo atuar em tempo real sobre as variáveis do modelo e observar na tela as transformações resultantes. Tais simulações podem servir para testar fenômenos ou situações em todas suas variações imagináveis, para pensar no conjunto de consequências e implicações de suposições e para conhecer melhor objetos ou sistemas complexos de maneira lúdica ${ }^{(30)}$.

A simulação virtual, como espaço protegido que reproduz cenários da prática, utilizada inicialmente para treinamento militar, demonstrou eficiência no preparo para o combate, conferindo alto grau de realismo e imersão total no mundo virtual. Esse resultado impulsionou o uso também em outras áreas, inclusive na educação e na saúde para formação e capacitação profissional, com minimização de erros que resultem em prejuízo ao paciente, garantindo a segurança no cuidado, em especial nas situações de emergência.

\subsection{EDUCAÇÃO ON-LINE E AS PERSPECTIVAS PEDAGÓGICAS}

$\mathrm{Na}$ formação e na capacitação dos profissionais da saúde e, especificamente, da enfermagem, a busca constante de informações e de aprendizagem é fundamental e deve ser facilitada por meio de processos de ensino que atendam às características desses profissionais ${ }^{(49)}$ que são adultos, têm consciência do que precisam saber e de que a aprendizagem se estabeleça a partir daquilo que o aprendiz já conhece a respeito do objeto de conhecimento ${ }^{(50)}$.

Assim, serão destacados os princípios da andragogia e os pressupostos da teoria da aprendizagem significativa (TAS) e as premissas da avaliação da aprendizagem que fundamentaram o desenvolvimento do curso on-line sobre SAV. Na enfermagem, esses aspectos pedagógicos tem balisado a educação on-line, por facilitarem o estabelecimento das pontes de significado por meio da contextualização, da pertinência e do modo de apresentação 
das informações e possibilitarem ao profissional enfermeiro estabelecer postura crítica e reflexiva sobre sua maneira de pensar e de agir ${ }^{(33,38,51)}$.

\subsubsection{Andragogia}

$\mathrm{Na}$ área de ciências da saúde, um estudo bibliométrico sobre andragogia ${ }^{(49)}$ realizado no período de 1999 a 2009, mostrou que 54\% das publicações estão relacionadas ao ensino de enfermagem. Estes resultados intencionaram indicar o impacto das produções científicas que utilizam a andragogia como recurso de aprendizagem de adultos na saúde, na formação profissional e na educação permanente, além de subsidiar outros estudos com esse enfoque e que tenham como finalidade contribuir para a melhoria da educação em saúde.

$\mathrm{Na}$ educação on-line em enfermagem, a andragogia também tem se destacado por conferir importância significativa no processo de ensino aprendizagem dos profissionais e auxiliar no desenvolvimento de novos conhecimentos e habilidades. Entretanto, para o êxito deste processo, é necessário que as instituições estejam alinhadas às mudanças contemporâneas da educação permanente em saúde, considerando os profissionais protagonistas do aprendizado.

No desenvolvimento de capacitação de adultos, algumas características peculiares precisam ser consideradas como os diferentes estilos, ritmos e espaços de aprendizagem de cada $\operatorname{aprendiz}^{(52)}$.

A andragogia, foi definida por Malcolm Knowles ${ }^{(53)}$, na década de 1970, como a arte ou a ciência de orientar adultos a aprender. Para Martins ${ }^{(54)}$, corresponde à ciência que estuda as melhores práticas para auxiliar adultos na aprendizagem, valorizando a experiência, como a fonte mais rica desse processo, pois leva a novas dimensões e à solução de problemas. Aproveitar experiências acumuladas e conferir significado ao aprendizado são princípios fundamentais no processo ensino aprendizagem do adulto ${ }^{(55)}$.

Com o amadurecimento, o adulto evolui o perfil, de dependente para autônomo e adota o reservatório de experiências como fonte de aprendizado. A perspectiva da utilização do conhecimento altera-se de tardia para imediata de acordo com as necessidades ${ }^{(56)}$. 
Os adultos são motivados a aprender conforme vivenciam necessidades e interesses pessoais e profissionais que exigem novos conhecimentos para ajudá-los a enfrentar problemas reais do cotidiano visando sua aplicação imediata ${ }^{(52,55,57)}$.

Desse modo, o adulto é agente de sua própria aprendizagem, interagindo e se apropriando de saberes que contribuem para sua autonomia, independência e autogestão ${ }^{(56)}$. Neste sentido, a proposta da andragogia é de enfatizar a aquisição de competências e a autodireção do aprendiz ${ }^{(58)}$.

O modelo andragógico ${ }^{(49,54,59)}$ baseia-se nos seguintes princípios:

- Necessidade de saber: adultos tem consciência da importância do conhecimento para a vida profissional e pessoal e busca aprender aquilo que realmente precisa saber;

- Autoconceito dos aprendizes: menos dependentes e são responsáveis por suas decisões e querem ser vistos pelos outros como capazes de autodirigir sua aprendizagem;

- Papel das experiências: constituem a base do aprendizado dessa faixa etária considerando relevantes em quantidade e qualidade (conhecimento e experiência), pois conduz a novos enfoques e resolução de problemas;

- Prontidão para aprender: disposição para aprender algo relacionado a situações reais de seu cotidiano e quando necessita de conhecimento para aplicação prática;

- Orientação para aprendizagem: maior adesão ao aprendizado quando os conceitos estão contextualizados com sua realidade na prática;

- Motivação: os valores intrínsecos como a autoestima, o reconhecimento e a melhoria na qualidade de vida permeiam a aprendizagem de adultos.

Considerando que os adultos são capazes de responsabilizar-se pela própria aprendizagem, a educação permanente pode ser baseada nos princípios do modelo andragógico e planejada de modo à estimular a autonomia do aprendiz, o compartilhamento de experiências e a aplicabilidade dos novos conhecimentos e competências nos diferentes contextos de sua $\operatorname{vida}^{(60)}$. 
O crescimento e o avanço da tecnologia e da web conferiram novas maneiras de conduzir o ensino e a aprendizagem de aprendizes adultos, com a possibilidade de novos espaços de interação, de comunicação e de concepções do processo de ensino ${ }^{(61)}$.

Mediante esses pressupostos, no ensino de adultos utilizando-se da educação on-line é possível integrar as TIC no desenvolvimento do conteúdo, criar inúmeras oportunidades de aprendizagem a fim de tornar os indivíduos mais participantes e autônomos na atual sociedade da informação, utilizar diferentes mídias com propósitos específicos para suprir as necessidades dessa faixa etária e explorar as potencialidades de cada idade ${ }^{(42)}$.

Nesse contexto, a incorporação das TIC no desenvolvimento de programas de educação on-line tem o intuito de possibilitar a prática pedagógica aderente ao contexto atual, baseada na interação, na inovação e na promoção da capacidade de autonomia do participante $^{(27)}$.

Na educação on-line de adultos, as características específicas dessa faixa etária podem contribuir positivamente no processo de ensino aprendizagem, visando à independência e à capacidade de estabelecer diferentes estratégias para seu aprendizado ${ }^{(33)}$. O sucesso do aprendizado dependerá em quase sua totalidade da autonomia, da responsabilidade e do esforço pessoal de quem aprende, sendo secundário o estímulo para aprender, como acontece no ensino a crianças e jovens.

A educação on-line favorece a aprendizagem autodirigida e autodeterminada com foco nas experiências prévias. Este espaço permite que o participante estabeleça o que e o como a aprendizagem deve acontecer e consiste em incentivo a reflexão pessoal e coletiva com valorização do conhecimento prévio. Os AVA também possibilitam a assimilação do aprendizado e das habilidades e rápida adaptação às mudanças sociais e aos modos de comunicação $^{(52)}$.

Para atender ao adulto, é relevante construir o AVA de modo a incentivar a interação e a colaboração entre pessoas com os mesmos interesses de aprendizado e assegurar que os conhecimentos sejam assimilados de maneira ágil e objetiva. A seleção dos conteúdos e materiais didáticos necessitam ser mais desafiadores, enriquecidos com oportunidades para que o participante possa aprender e verificar o aprendido, assim como, se apropriar do conhecimento, permitindo ir além da retenção de conteúdo ${ }^{(62)}$. 
Nesse sentido, a avaliação da aprendizagem na educação on-line consiste no processo que acompanha todo o percurso das atividades de ensino, mediados pelas diversas tecnologias e merece destaque no âmbito do contexto dialógico, colaborativo, participativo, contextualizado, abrangente, reflexivo, enfim, ferramenta de mudança, que busque aproximar os aprendizes da interação e possa engendrar nova sensibilidade aos programas de formação e capacitação em ambientes digitais ${ }^{(63,64,65)}$.

A avaliação de aprendizagem on-line pode ser baseada em desempenho por meio de testes objetivos e ou outros mecanismos de autocorreção pelo sistema computacional, ou ocorrer por meio de monitoramento das atividades desenvolvidas pelos aprendizes no AVA (resultados das participações nos fóruns, discussões ou dos acessos ao ambiente), seja na dimensão quantitativa (frequência de participações) quanto qualitativa (análise do conteúdo das produções). Essa amplitude de dados, garantida pelo registro na tela, favorece a avaliação do curso integralmente ${ }^{(63,66)}$.

Os instrumentos e as estratégias utilizados na avaliação da aprendizagem mediada pelas diferentes tecnologias para desenvolver a autonomia do aprendiz, visto que este deve ser o responsável por sua aprendizagem são: questionários, auto avaliações, análises crítica das interações nos fóruns e chats, portfólios, diários das atividades, entrevistas estruturadas, pesquisas de opinião, discussões, observações, cenários, feedbacks críticos, estudos de caso, projetos individuais e coletivos, jogos e simulações ${ }^{(65,67,68)}$.

A variedade de informações e dos modos de avaliação permite ao aprendiz conhecer melhor suas condições, facilidades, deficiências, motivações, atitudes, que servem como subsídio na busca de atividades ou estratégias para enriquecer sua aprendizagem e aperfeiçoar seus resultados. Na avaliação, é importante incluir situações da vida real e problemas significativos, que possibilitam compreender os fenômenos e conhecer melhor a sua natureza ${ }^{(69)}$.

No que se refere às diversas maneiras de avaliação da aprendizagem determinadas com base nas funções que exercem no processo avaliativo são denominadas: diagnóstica (antes do processo), formativa (durante o processo) e somativa (após o processo).

A avaliação diagnóstica é importante para delinear o perfil dos participantes, fornecer subsídios que explicitem possibilidades a serem exploradas no planejamento e no desenvolvimento de atividades propostas durante o processo ensino aprendizagem de cursos 
que admita flexibilidades, reconfigurações, encaixes e revisões ${ }^{(65,70)}$. Esta modalidade avaliativa considera as especificidades de cada aprendiz, sua possibilidade colaborativa e sua história, o que significa o respeito à sua trajetória, saberes e competências prévias, expectativas, dificuldades e potencialidades ${ }^{(65)}$.

No ambiente virtual, a avaliação diagnóstica da aprendizagem é transformadora, na medida em que o aprendiz poderá identificar suas lacunas de conhecimento, tomar consciência delas, transformá-las em algo instrutivo e construtivo e vê-las como alavanca para levantar hipóteses e planejar estratégias de ação. E como resultado da diversidade desses percursos individuais, os aprendizes serão capazes de raciocinar e de se posicionar de modo independente ${ }^{(67)}$.

A avaliação formativa tem por finalidade auxiliar o aprendiz a aprender e a se desenvolver ${ }^{(71)}$ e, quando contextualizada, fornece feedback aos professores e aprendizes para suas intervenções no processo de ensino aprendizagem, visando garantir a qualidade ${ }^{(65)}$.

A avaliação formativa caracteriza-se pela ocorrência de avaliação continuada e processual que permeia toda estratégia pedagógica do curso, permite verificar a compatibilidade entre os objetivos traçados e os resultados alcançados, busca compreender as ocorrências e as causas de dificuldades e possibilita ao aprendiz ações pedagógicas consistentes que intencionam auxiliar a aprendizagem e alcançar o domínio que dele se espera naquele momento, considerando seus interesses, aspirações, experiências e reais necessidades ${ }^{(56,65)}$.

Avaliação somativa, ou de resultado, refere-se à modalidade avaliativa realizada ao término da proposta educacional com a intencionalidade de verificar se a aprendizagem efetivada corresponde à esperada, julgar a qualidade dessa aprendizagem e atribuir-lhe valor, conforme padrão e determinação previamente definidos pela instituição. Os resultados desses julgamentos, geralmente, são os responsáveis pela promoção ou reprovação do aprendiz ${ }^{(65,72)}$. Em determinados contextos, a avaliação somativa tem efeito de congelamento e não permite ao aprendiz utilizar os próprios erros para experiência e aprendizado ${ }^{(65)}$.

\subsubsection{Teoria da aprendizagem significativa}

Na Teoria da Aprendizagem Significativa, proposta por Ausubel na década de 60, para que a aprendizagem se consolide é necessário existir vínculo entre a nova informação e as 
previamente conhecidas e relevantes ao aprendiz, tornando-a significativa para o mesmo, por meio da ancoragem com a estrutura cognitiva preexistente ${ }^{(73)}$.

A conectividade do novo conteúdo, com aqueles já conhecidos, intenciona promover desequilíbrios cognitivos, que favoreçam a reorganização da estrutura cognitiva, de maneira a integrar alterações conceituais decorrentes das recentes informações. Implicitamente, há a preocupação em conduzir o estudante a aprender a aprender e a encontrar caminhos cognitivos para a resolução de problemas e ampliação dos próprios saberes ${ }^{(74)}$.

Para que os conteúdos sejam potencialmente significativos exigem compatibilidade com a estrutura cognitiva prévia do aprendiz. O aproveitamento destes conteúdos dependerá da motivação para realizar diversas operações cognitivas das quais resulta o aprendizado. Estas operações caracterizam o aprendizado significativo como ativo e começam pela identificação de concepções previamente conhecidas com conexões às novas proposições ${ }^{(75)}$.

$\mathrm{Na}$ aprendizagem significativa, a nova informação tem de interagir com os conhecimentos prévios do aprendiz que incluem os conceitos, as proposições e os símbolos

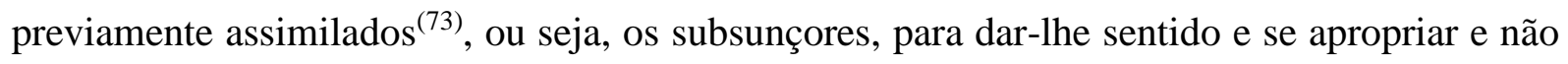
apenas sobrevir a simples memorização de informações. E para acontecer a memorização em longo prazo, o novo conceito tem que se conectar com o que o aprendiz já sabe ou com o que lhe é familiar. Se não houver conceito prévio para que ocorra a conexão da informação, a aprendizagem será mecânica ${ }^{(75,76)}$.

Para que a aprendizagem significativa ${ }^{(33,73)}$ ocorra, algumas condições se fazem necessárias: a) a confrontação do aprendiz com o conteúdo potencialmente relevante, ou seja, tenha significado lógico, isto é, que seja coerente com qualquer estrutura cognitiva apropriada, portanto seja não arbitrário; trata-se de característica do próprio conteúdo e que existam subsunçores adequados no aprendiz que permitam a assimilação desse novo conteúdo; b) que o aprendiz tenha predisposição psicológica para aprender de maneira significativa.

As concepções da aprendizagem significativa e os subsunçores dão sustentação às ações de curso, fundamentando o desenvolvimento dos materiais educacionais digitais, o desenho do curso e a seleção das atividades de aprendizagem de modo a possibilitar condições favoráveis para que a aprendizagem se concretize ${ }^{(33)}$. 
$\mathrm{Na}$ aprendizagem significativa, a diferenciação progressiva consiste em estratégia para construir o princípio programático em que as ideias mais gerais e inclusivas do conteúdo são introduzidas no início da orientação e, gradativamente, são diferenciadas em termos de detalhes e especificidades. A aprendizagem significativa ocorre de maneira gradativa, assim, os conceitos vão sendo captados e internalizados progressivamente.

Dessa maneira, embora o foco da teoria de Ausubel, da aprendizagem significativa, esteja no indivíduo, ancorado em conhecimentos prévios e em sua capacidade de estabelecer a aquisição e a retenção dos novos conceitos, o conteúdo programático deve ser potencialmente significativo para o aprendiz, ou seja, tanto no que diz respeito ao ambiente de aprendizagem, quanto ao material educacional digital apresentado ${ }^{(33)}$. Nessa vertente, os processos que promovem e produzem sentido são os princípios que norteiam a educação permanente em saúde.

Essa teoria proposta por Ausubel pode ser utilizada na educação dos profissionais da área da saúde, com ênfase na apresentação do atual e do diferente, para a reelaboração de conceitos, a partir do conhecimento prévio e da retenção do que faz sentido e é relevante para a transformação da prática profissional ${ }^{(55)}$.

As ações educacionais têm avançado na direção da autonomia do aprendiz priorizando estratégias que levem ao desenvolvimento integral em suas capacidades cognitivas, afetivas e psicomotoras, com vistas à aprendizagem significativa e contínua, articulada a seu projeto de vida e de formação ${ }^{(77)}$.

A inclusão das TIC na educação permanente leva a mudança na postura do professor, que deixa de ser o detentor do saber, para tornar-se facilitador da aprendizagem, que auxiliará na reconstrução de conceitos e permitirá ao profissional aprender de modo significativo ${ }^{(78)}$.

Nos ambientes virtuais, a TAS pode colaborar na seleção das ferramentas de apoio à aprendizagem e na estruturação do processo de aprendizagem baseadas nos objetivos educacionais almejados para que sejam viáveis. E, ainda, pode ser empregada no desenvolvimento de recursos pedagógicos como objetos de aprendizagem, vídeos, jogos digitais, animações e simulações ${ }^{(78)}$.

A TAS é capaz de potencializar o processo de ensino aprendizagem ao valorizar as experiências e o saber adquirido pelo aprendiz ao longo da vida e de priorizar a construção de 
sentido para a tomada de consciência sobre seu processo de aprendizagem, assim como, a participação ativa na apropriação do conhecimento ${ }^{(78)}$.

\subsection{DESIGN INSTRUCIONAL E A EDUCAÇÃO ON-LINE}

$\mathrm{Na}$ educação on-line, é de suma importância estabelecer princípios e métodos de instrução que sejam adequados a diferentes estilos de aprendizagem e estejam fundamentados na ciência de informação, mais especificamente nas comunicações, nas mídias audiovisuais, na gestão da informação e na ciência da computação ${ }^{(31)}$.

Neste processo o Design Instrucional (DI) é compreendido como à ação intencional e sistemática de ensino, que abrange o planejamento, o desenvolvimento e a utilização de métodos, técnicas, atividades e produtos educacionais, em situações didáticas específicas, a fim de favorecer o aprendizado, partindo de princípios de aprendizagem e instrução conhecidos ${ }^{(28)}$.

O DI tem como finalidade oferecer subsídios para tornar o aprendizado on-line mais eficiente e dinâmico. Os objetivos e a avaliação da aprendizagem precisam estar alinhados às estratégias, aos materiais didáticos e recursos tecnológicos - textos, hipertextos, imagens, gráficos, sons e movimentos, jogos digitais, simulações virtuais, atividades e tarefas - e ancorados em suportes virtuais, com foco na necessidade do aprendiz ${ }^{(79,80)}$.

Nesse contexto, ao incorporar as TIC como a internet no processo de desenvolvimento da educação on-line, o DI admite mecanismos de efetiva contextualização que se caracteriza pela maior personalização aos estilos e ritmos individuais de aprendizagem, atualização por meio de feedback, acesso a experiências externas à organização de ensino, comunicação entre professores, aprendizes, equipe técnica e pedagógica e monitoramento automático da construção individual e coletiva de conhecimentos ${ }^{(81)}$.

Para Alavarce ${ }^{(33)}$, o desenvolvimento de curso on-line é tarefa complexa, que exige grande investimento financeiro, envolve profissionais de várias áreas do saber como web designer, pedagogos, designer educacional e especialista do tema em questão, bem como requer conhecimento profundo do que se quer ensinar, das diferentes teorias de aprendizagem, dos 
limites e das possibilidades que o ambiente on-line apresenta, das diversas mídias e modos de comunicação digital e das novidades tecnológicas que o mercado oferece.

Os recursos e as estratégias tecnológicas disponíveis para fins educacionais são infinitos; no entanto, para obtenção de resultado satisfatório, depende da maneira como as novas tecnologias são empregadas no cumprimento dos objetivos propostos. Sendo assim, é necessário conhecê-las, selecioná-las e utilizá-las adequadamente no desenvolvimento de produtos educacionais voltados ao ensino on-line.

As necessidades de aprendizado e aprimoramento constantes que permitam conciliar as ações educacionais com as demandas pessoais e profissionais implicam em crescente interesse pela expansão de cursos on-line. Entretanto, a criação destes requer a sistematização do processo de planejamento, de produção, de implementação e de avaliação norteada pelo DI.

Existem vários modelos de design instrucional para nortear o planejamento e o desenvolvimento de ambientes virtuais de aprendizagem. Pesquisadores da Universidade de Frankfurt implementaram, em 2009, o procedimento Modelo denominado AKUE, destinado a garantir a qualidade e o custo benefício na produção de cursos de aprendizagem on-line. A sigla AKUE representa as iniciais das fases - Analyse, Konzeption, Umsetzung e Evaluation (análise, concepção, implementação e avaliação) - na língua Alemã e o objetivo dessas etapas consiste em identificar possíveis falhas durante o processo de planejamento e desenvolvimento antes de seguir para próxima etapa ${ }^{(51,81,82)}$.

O ADDIE, que é o acrônimo para as cinco fases do Instructional System Design: Analysis, Design, Development, Implementation e Evaluation também é utilizado para desenvolvimento de cursos / unidades de aprendizagem on-line. Este modelo pode ser definido como o método sistemático e interativo para a criação de plataformas de aprendizagem com o intuito de desenvolver e melhorar habilidades e conhecimentos dos aprendizes ${ }^{(51,83)}$.

O Design Instrucional Contextualizado (DIC), modelo desenvolvido com base no ADDIE, para criação de cursos presenciais e em ambientes virtuais de aprendizagem é constituído por 5 fases: Análise; Desenho; Desenvolvimento; Implementação e Avaliação ${ }^{(31)}$.

O diferencial do DIC compreende ações intencionais, cíclicas e sistemáticas de ensino que envolve o processo para identificar o problema de aprendizagem e desenhar, desenvolver, implementar e avaliar soluções didáticas específicas para esse problema que, valendo-se das 
potencialidades da internet, incorporem, tanto na fase de concepção como durante a implementação, mecanismos que favoreçam a contextualização e a flexibilização e permitam realizar as alterações necessárias durante o desenrolar do curso à medida que são identificadas $^{(31)}$.

O DIC refere-se ao processo dinâmico de planejar, de desenvolver e de aplicar situações de aprendizagem flexíveis, dialógicas e não lineares, baseadas na perspectiva individual, cultural, organizacional e contextual dos participantes do processo educacional ${ }^{(84)}$.

A adoção do DIC na elaboração de cursos on-line possibilita aos usuários características de recursividade e versatilidade no modo de apresentar e acessar as informações contidas no ambiente, por meio de recursos de imagens, vídeos, áudios, hipertextos, simulações, videoconferências, entre outros, que flexibilizam o ensino e harmonizam-se dinamicamente, viabilizam mudanças e contínuas atualizações de modo a garantir a obtenção das necessidades e dos objetivos dos participantes e propiciam a interação com ferramentas comunicacionais e mídias de maneira dinâmica, mutante e coletiva ${ }^{(28,80)}$.

A utilização de diversas mídias ${ }^{(31)}$ estimula o desenvolvimento de diferentes habilidades de processamento da informação e, consequentemente, como resultado, cada mídia requer distintas considerações de DI.

No DIC ${ }^{(80,85)}$, as fases de análise, design, desenvolvimento, implementação e avaliação, são dependentes e representam uma rede dinâmica de partes que se conectam umas às outras e acontecem recursivamente ao longo de todo o processo, conforme demonstradas na Figura 1. 
Figura 1 - Fases do Design Instrucional Contextualizado.

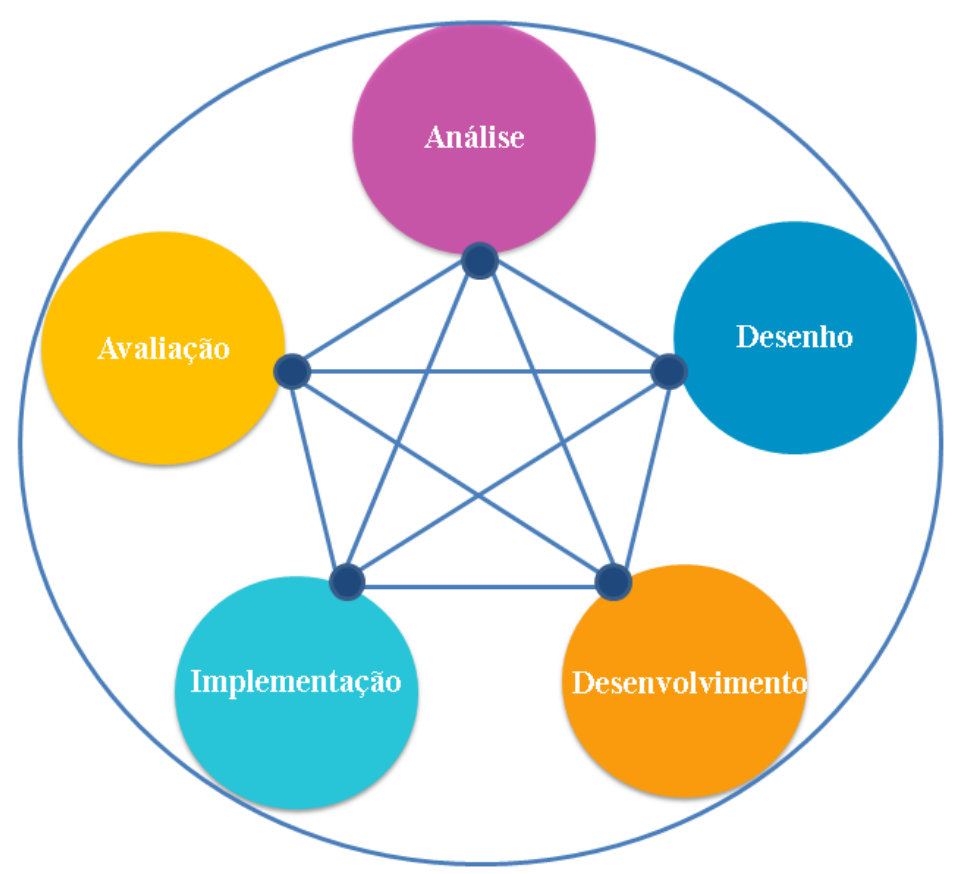

Fonte: Adaptado de Filatro A. Design instrucional contextualizado. São Paulo: Senac; 2007.

\subsubsection{Análise}

A análise, na perspectiva do DIC, consiste em entender o problema educacional e projetar solução pertinente, que deve ser aprimorada, constantemente, com a participação de aprendizes, de especialistas e de professores. É a etapa inicial do desenvolvimento de sistemas de aprendizagem on-line, onde são fundamentais a análise cuidadosa das necessidades educacionais propriamente ditas, a caracterização dos participantes e a verificação de restrições relacionadas às questões de infraestrutura e de recursos financeiros, tecnológicos e humanos para desenvolvimento e implementação do projeto $^{(31,84,86)}$.

Na concepção de projetos educacionais, é necessário realizar a previsão de gastos, estimar os custos - benefícios e os diretos, visando verificar a viabilidade dos programas, a previsão orçamentária, bem como são ponderados diversos fatores relacionados aos custos de produção do curso ${ }^{(38,51)}$.

No desenvolvimento de curso on-line, a estimativa dos custos é complexa e de difícil precisão, principalmente, em razão, da necessidade de envolvimento de equipe multidisciplinar e da adoção de recursos tecnológicos e da criação de objetos de aprendizagem. 


\subsubsection{Desenho}

A fase de desenho abrange o planejamento e a estrutura da situação didática propriamente dita, com especificação do cenário, da concepção pedagógica que fundamentará a aprendizagem, da definição dos objetivos educacionais, do mapeamento e sequenciamento dos conteúdos a serem trabalhados, do estabelecimento das unidades de aprendizagem, da seleção de estratégias, de mídias e de ferramentas mais apropriadas para alcançar os objetivos traçados, assim como, a estrutura de navegação e outros requisitos específicos do contexto que podem ser estruturados a partir da matriz de design instrucional ${ }^{(23,31,86)}$.

A matriz norteadora do DIC permite ter visão panorâmica de cada unidade de aprendizagem e pode ser apresentada como o mapa do curso para a orientação da equipe de design e de desenvolvimento instrucional. A unidade de aprendizagem contém todos os elementos necessários ao processo ensino aprendizagem ${ }^{(31)}$.

\subsubsection{Desenvolvimento}

O desenvolvimento consiste na materialização de todo o planejamento elaborado nas fases de análise e de desenho, onde é produzido o material necessário para a execução das atividades delineadas. Nesta etapa é definida a melhor maneira de construir e validar o que foi planejado $^{(31)}$.

Essas duas últimas fases exigem maior dedicação e disponibilidade de tempo dos desenvolvedores, correspondendo à elaboração dos conteúdos, ao estabelecimento das atividades, ao sistema de avaliação, bem como à organização das ferramentas e mídias e a estrutura de navegação da proposta no AVA.

\subsubsection{Implementação}

A fase de implementação ${ }^{(31)}$ é constituída de duas etapas:

- Publicação - consiste na disponibilização do conteúdo e na configuração das ferramentas e dos recursos tecnológicos educacionais no AVA; 
- Execução - possibilita o acesso ao curso pela internet. Aplicação da proposta de design instrucional. É a fase de execução propriamente dita.

\subsubsection{Avaliação}

Na quinta e última fase do DI, denominada de avaliação, são identificadas as falhas nos níveis de análise, de desenho, de desenvolvimento e de funcionamento da proposta educacional e analisados os resultados de aprendizagem, bem como realizada a revisão e os ajustes do conteúdo e dos componentes educacionais e tecnológicos do curso. Nesta fase ocorre, também, a manutenção, que visa à continuidade do $\operatorname{processo}^{(31)}$.

Como parte das ações educacionais, o feedback - significa realimentar ou dar resposta e receber opiniões, críticas e sugestões a determinado pedido, acontecimento, processo ou atividade, que pode ser positivo ou negativo - assume papel essencial na retroalimentação ou devolutiva das práticas e da avaliação educacional para a equipe de DI durante o desenvolvimento e a implementação do curso, e aos aprendizes, oportunidades de pensar sobre sua própria aprendizagem ${ }^{(28)}$.

$\mathrm{Na}$ criação de curso on-line, as diferentes fases do DI constituem eixos fundamentais de avaliação $^{(62)} \mathrm{e}$, portanto, esta permeará todo o processo de construção e moldagem do material didático.

A avaliação consiste em ação fundamental para qualquer empreendimento gerador de produtos que serão utilizados para fins educacionais ${ }^{(87)}$. Em relação aos cursos on-line, a avaliação depende de um grupo de técnicas de análise e métricas que oferecem informações sobre as características / aspectos de qualidade do produto. É por meio desses aspectos que o curso é analisado, avaliado e verificado se atende às necessidades do usuário, sendo então, determinada sua qualidade ${ }^{(87,88)}$.

A avaliação da qualidade de cursos on-line é um processo complexo que exige o uso de métricas de maneira consistente, podendo ser necessário desenvolver novos padrões, critérios ou realizar adaptações para uso específico, a fim de assegurar confiança e funcionalidade no contexto de sua aplicação para a obtenção dos objetivos almejados ${ }^{(88)}$. 
Estudiosos do assunto apontam a ausência de padronização e de linguagem de avaliação da qualidade nessa área ${ }^{(89)}$. Entretanto, o método mais adotado tem sido o checklist, partindo do referencial da avaliação de Softwares Educacionais (SE) que utiliza o conjunto de questões específicas e preestabelecidas, para conduzir o processo de avaliação e verificar se o produto contempla ou não os critérios e os pressupostos educacionais ${ }^{(90,91)}$.

Destaca-se, ainda, a importância de avaliar o funcionamento adequado do ambiente de aprendizagem e das ferramentas tecnológicas, o alinhamento dos elementos pedagógicos relacionados aos objetivos, conteúdos abordados, estratégias estabelecidas e avaliações da aprendizagem, bem como a congruência entre a interface e as características, necessidades e limitações dos usuários ${ }^{(92)}$.

Métodos específicos para o controle da qualidade de softwares educacionais devem ser utilizados para avaliar a contribuição efetiva para o processo ensino aprendizagem, os resultados de sua utilização pelos aprendizes bem como quanto os benefícios no que se refere ao desempenho do produto $^{(93)}$.

$\mathrm{Na}$ avaliação da qualidade de cursos on-line, é imprescindível analisar se os objetivos foram alcançados, o produto atingiu sua meta, as ferramentas foram adequadas e o material didático atingiu seu propósito, visando fornecer dados para que se possa realizar a retroalimentação do processo de desenvolvimento, correções e melhorias. 
2 OBJETIVOS 



\section{OBJETIVOS}

- Desenvolver o curso on-line sobre Suporte Avançado de Vida em Parada Cardiorrespiratória de adulto para enfermeiros;

- Avaliar a qualidade do curso on-line na perspectiva de especialistas. 




\section{MATERIAL E MÉTODO}

\subsection{TIPO DE PESQUISA}

O estudo constituiu-se de pesquisa metodológica aplicada, na modalidade de produção tecnológica de natureza quantitativa, exploratória e descritiva para o desenvolvimento de curso on-line visando a educação permanente de enfermeiros em atendimento de PCR no SAV.

A pesquisa metodológica ${ }^{(80)}$ foi selecionada por tratar-se do processo de desenvolvimento de novo produto, atividade ou serviço, ou seja, ambiente virtual de aprendizagem sobre SAV em PCR de adultos para enfermeiros.

A pesquisa aplicada de produção tecnológica concentra-se em encontrar solução imediata para o problema existente, por meio da criação de produtos ${ }^{(94)}$. Foi adotada neste estudo por tratar-se de proposta de desenvolvimento de curso on-line utilizando a plataforma AVA Moodle ${ }^{\circledR}$ e instrumentos específicos.

A abordagem quantitativa adotada nesse estudo está relacionada ao emprego de recursos estatísticos que visam quantificar os dados coletados. No desenvolvimento da pesquisa de natureza quantitativa, considera-se que todas as informações coletadas podem ser quantificáveis, ou seja, traduzidas em números, classificadas, analisadas e os resultados replicados ${ }^{(95)}$.

\subsection{PARTICIPANTES DO ESTUDO}

Para atender ao segundo objetivo acerca da avaliação do curso por especialistas a seleção dos participantes foi aleatória, intencional e não probabilística, constituída por profissionais enfermeiros especialistas de reconhecido saber, em exercício, com compatibilidade e identidade com a área do estudo desenvolvido e que apresentam engajamento tanto no ensino e na pesquisa quanto na assistência. 
O número de especialistas foi estabelecido de acordo com as recomendações da Norma Brasileira da Associação Brasileira de Normas Técnicas, de acordo com o International Organization for Standartization International Eletrotechnical Commission ABNT NBR ISO/IEC 14598-6, que indica o mínimo de oito avaliadores especialistas de cada categoria ou área de conhecimento, para obtenção de números confiáveis ${ }^{(88)}$.

Para tanto foram convidados a participarem do estudo, vinte e seis enfermeiros que atendiam os critérios de inclusão a seguir:

- ser enfermeiro com atuação na área de urgência e emergência ao adulto de, no mínimo, dois anos; ou

- ser enfermeiro com experiência em educação on-line de, no mínimo, dois anos.

\subsection{PROCEDIMENTO E INSTRUMENTO DE COLETA DE DADOS}

No primeiro momento, ocorreu a construção do curso on-line no ambiente virtual de aprendizagem Moodle ${ }^{\circledR}$ orientada pelo design instrucional contextualizado seguindo as fases de análise, desenho, desenvolvimento, implementação e avaliação ${ }^{(28)}$. No segundo momento, o curso on-line foi avaliado por especialistas, conforme Figura 2. 
Figura 2 - Representação do delineamento metodológico da pesquisa.

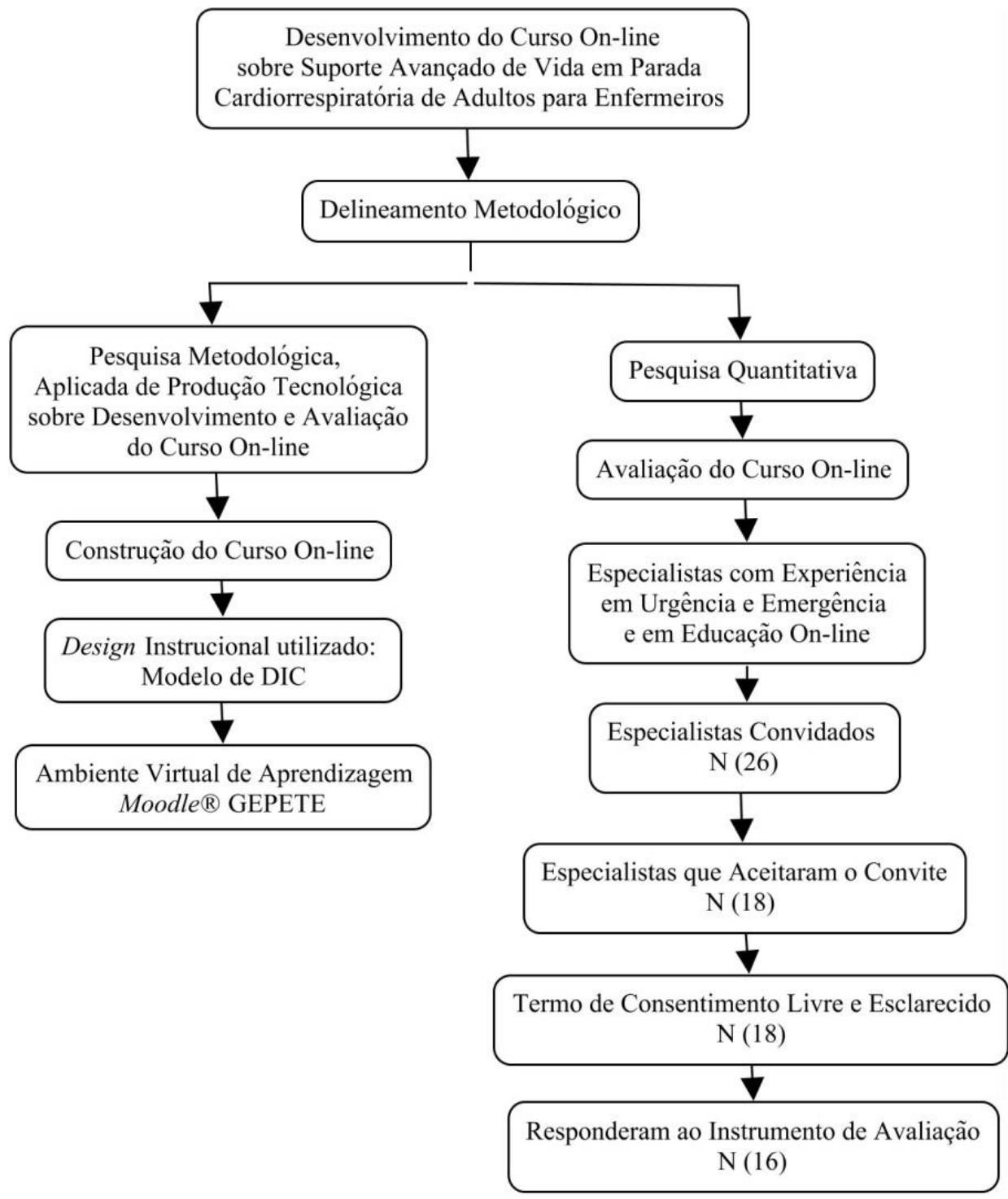

Fonte: Dados da pesquisa.

A coleta de dados foi realizada após aprovação do Comitê de Ética em Pesquisa da Escola de Enfermagem da Universidade de São Paulo. Essa fase constitui-se parte importante da pesquisa no que tange a qualidade das informações obtidas para responder a pergunta do estudo sobre a avaliação do curso on-line.

O período de coleta de dados foi de novembro a dezembro de 2016. Este prazo foi necessário para obtenção do número mínimo de avaliadores para cada categoria, recomendado pela NBR ISO/IEC $14598-6^{(88)}$.

Os especialistas foram convidados por meio de carta convite (APÊNDICE A) enviada por e-mail, os quais foram orientados em relação às finalidades e objetivos da pesquisa, às 
etapas do processo e como estas aconteceriam e à importância da participação do mesmo em responder a avaliação em tempo hábil.

A carta convite foi enviada para 26 especialistas e, destes, dezoito aceitaram participar da pesquisa. Ao final de vinte dias, treze avaliaram o curso. Por este número ser insuficiente, conforme os critérios da NBR, o prazo foi ampliado por mais dez dias, período em que outros três especialistas realizaram a avaliação do curso, totalizando dezesseis avaliações.

Aos especialistas que se dispuseram participar da avaliação do curso on-line no AVA, foram enviados o Termo de Consentimento Livre e Esclarecido - TCLE (APÊNDICE B), o tutorial com o link e a senha de acesso ao ambiente virtual, os contatos do pesquisador para esclarecimentos de dúvidas, bem como o link para o posterior preenchimento do formulário de avaliação. O TCLE foi assinado por meio digital no momento em que o especialista confirmava o aceite em participar da pesquisa ao iniciar o preenchimento do instrumento de avaliação do curso.

O instrumento de avaliação (ANEXO A) foi digitalizado e hospedado na internet, utilizando a ferramenta do Google, o "Google Docs". O link de acesso ao documento foi enviado aos respondentes da pesquisa, via $e$-mail.

Durante a avaliação, os especialistas puderam contatar a pesquisadora, por correio eletrônico para esclarecer dúvidas técnicas referentes ao tema e dificuldades encontradas no acesso ao ambiente virtual de aprendizagem Moodle ${ }^{\circledR}$.

O instrumento de coleta de dados foi composto por breve seção de caracterização do avaliador, como idade, sexo, formação profissional, tempo de formação profissional, experiência profissional (área, cargo/função e tempo de atuação), seguida de 20 questões de múltipla escolha para avaliação da qualidade do curso on-line.

A avaliação da qualidade do curso on-line foi baseada nos critérios descritos no "Instrumento para Avaliação da Qualidade de Objetos de Aprendizagem na perspectiva do usuário", versão 5.0, propostos pela Coordenação Central de Educação a Distância ${ }^{(96)}$, da Pontifícia Universidade Católica do Rio de Janeiro (PUC-RJ).

Considerando que a avaliação de qualidade de produto/curso é tarefa complexa, foi adotado o instrumento da PUC-RJ por se tratar de modelo de avaliação de reconhecido valor, validado e utilizado por renomadas instuições de ensino e pesquisadores e por estabelecer os 
critérios para julgamento da qualidade de software educacional, além de conter indicadores condizentes à avaliação de curso on-line, objeto da pesquisa.

Esse instrumento é composto por três categorias (software, vídeo e áudio) sendo que, nesse estudo, utilizou-se a categoria de avaliação de software que abrange os seguintes critérios $^{(96)}$ : Navegação, Clareza das Informações, Facilidade de Localização das Informações, Pertinência, Contextualização, Correção de Conteúdo, Múltiplas Janelas, Facilidade de Aprendizagem na Interação, Eficiência de Utilização, Facilidade de Retorno, Ergonomia, Estética, Uso de Marcas Especiais, Utilização de Recursos Audiovisuais, Referências, Interatividade, Gestão de Erros, Ajuda aos Usuários, Qualidade da Informação e Portabilidade.

Os valores de cada critério avaliado variam entre $0-0,25-0,5-0,75-1$, onde 0 representa a avaliação mais negativa do critério e 1 , a mais positiva.

No instrumento de avaliação foi disponibilizado espaço para os especialistas justificarem os valores atribuídos e indicarem sugestões para a melhoria do curso. As instruções ${ }^{(96)}$ para avaliação e preenchimento do instrumento estão descritas no ANEXO A.

O cálculo final dos valores da medida ${ }^{(38,93)}$ e respectiva interpretação consideram que:

- 0,95 - 1,00 corresponde a alta qualidade;

- $\quad 0,90-0,94$ indica a qualidade boa;

- $0,60-0,89$ corresponde a qualidade mediana;

- $0,00-0,59$ equivale a ausência de qualidade.

\subsection{MÉTODO DE DESENVOLVIMENTO DO CURSO ON-LINE}

Para o desenvolvimento do curso on-line, baseou-se no Design Instrucional Contextualizado (DIC) estruturado a partir das fases de análise, de design, de desenvolvimento, de implementação e de avaliação $^{(28)}$. 


\subsubsection{Análise}

Esta primeira fase envolveu a escolha do tema, do público-alvo e do referencial bibliográfico, bem como a análise da infraestrutura e de investimentos necessários para a realização do curso ${ }^{(28)}$.

Para este curso, o AVA selecionado foi a plataforma Moodle® do GEPETE, versão 3.1, em razão de sua disponibilidade livre e gratuita e por possibilitar a criação de cursos on-line interativos, flexíveis e colaborativos, bem como a gestão do processo de ensino aprendizagem no contexto individual e coletivo.

Este curso foi concebido para ser oferecido on-line por meio do acesso ao computador ou, ainda, tablets, celulares e outros dispositivos móveis visando oportunizar acesso para o maior número de enfermeiros.

Em relação aos recursos humanos, contou com o apoio de uma enfermeira, doutora e pesquisadora vinculada ao GEPETE e à empresa HIPOCAMPUS, com experiência em design instrucional para o tratamento de imagens e o desenvolvimento dos objetos de aprendizagem, do layout e da estrutura do curso.

\subsubsection{Desenho}

Nesta fase, foi realizado o planejamento da estrutura do curso com especificação do cenário, da concepção pedagógica, da definição dos objetivos, dos conteúdos a serem trabalhados, assim como a seleção dos métodos, das técnicas, das mídias e dos materiais a serem produzidos para alcançar os objetivos traçados, bem como as estratégias de avaliação ${ }^{(23,28,31,85)}$.

O desenho do curso foi fundamentado nas perspectivas pedagógicas da andragogia e da Teoria da Aprendizagem Significativa, concernente à educação do adulto, valorizando conhecimentos prévios e experiências vividas pelo participante para ancorar novos aprendizados no preparo às ações resolutivas e qualificadas, no atendimento à PCR.

A construção dos objetivos educacionais foi baseada na Taxonomia de Bloom ${ }^{(97)}$, escolhida como referência por explicitar de maneira clara e objetiva o que se espera dos participantes após a ação educativa. Ainda, para direcionar a equipe de desenvolvedores foi 
elaborada a matriz de design instrucional que possibilita visualizar sinteticamente cada unidade de aprendizagem e seus componentes (APÊNDICE C ).

O tema central do curso on-line foi dividido em nove unidades de aprendizagem seguindo a mesma estrutura didática que integra os objetos de aprendizagem, os exercícios interativos, as estratégias de aprendizagens e as avaliações diagnóstica, formativa e somativa. O conteúdo do curso foi fundamentado nas diretrizes internacionais do programa "Suporte Avançado de Vida em Cardiologia" (Cardiology Advanced Life Support - ACLS) publicadas pela AHA para o atendimento de PCR em 2015 e nas orientações da Sociedade Brasileira de Cardiologia.

Nessa fase, o material didático das unidades de aprendizagem foi mapeado e traduzido no formato de storyboard pela pesquisadora, a partir dos objetivos pré-estabelecidos, com auxílio do recurso editor de apresentações do PowerPoint ${ }^{\circledR}$ e de textos do Word® da Microsoft, para desenvolvimento e implementação no AVA pela empresa especializada.

O conteúdo das unidades de aprendizagem, bem como os storyboards foram revisados pela pesquisadora e por outras três enfermeiras que atuam em emergência e experiência em urgência e emergência, educação continuada e ensino à distância. As complementações e alterações foram realizadas à medida que eram identificadas.

O processo avaliativo foi delineado prevendo a aplicação de atividades antes, durante e após o curso, constituindo as avaliações:

- Diagnóstica: realizada no início do curso com questões específicas de cada unidade de aprendizagem;

- Formativa: exercícios e jogos digitais com feedback ao longo do curso;

- Somativa: teste final no formato de simulação para avaliar o desempenho do participante na tomada de decisão quanto as intervenções prioritárias de SAV no atendimento à PCR.

O material desenvolvido nessa fase de desenho balisou a consecução da etapa de desenvolvimento. 


\subsubsection{Desenvolvimento}

No desenvolvimento, efetuou-se a produção de atividades e materiais didáticos planejados nas fases anteriores, como os conteúdos, os objetos de aprendizagem e os métodos de avaliação, bem como a organização das ferramentas e a determinação do grau de interação e interatividade desejados, no design do material e na preparação dos suportes pedagógico, administrativo e tecnológico ${ }^{(28,50)}$.

Nessa fase, foi elaborado o Tutorial visando apresentar aos participantes a proposta do curso, expor a importância do tema, descrever os objetivos e os assuntos abordados nas unidades de aprendizagem, bem como as orientações gerais e a rota de navegação para realização do curso.

Para apresentação das unidades de aprendizagem, foi utilizado o recurso Lição do Moodle ${ }^{\circledR}$ versão 3.1, que tem por objetivos disponibilizar conteúdos como textos, ilustrações e exercícios com perguntas de múltipla escolha, no formato de lição, organizados em várias páginas, com capítulos, subcapítulos e, ainda, proporcionar maior dinamicidade aos conteúdos selecionados e elaborados para o curso, além de prover menu de navegação automático ${ }^{(79)}$.

As principais vantagens do recurso Lição do Moodle ${ }^{\circledR}$ consistem em apresentar o material didático das unidades de aprendizagem, de maneira organizada, dinâmica e não linear funcionando como hipertexto.

As nove unidades de aprendizagem construídas a partir do recurso Lição do Moodle ${ }^{\circledR}$ apresentam a estrutura a seguir:

- Objetivos educacionais;

- Conteúdo (textos, imagens, vídeos, artigos, links de sites e de materiais complementares);

- Exercícios;

- Síntese do conteúdo;

- Jogo digital educacional;

- Referências. 
Para compor o material didático das unidades de aprendizagem foram produzidos objetos de aprendizagem (OA) em diversos formatos como imagens, ilustrações, hipertextos, simulação virtual, vídeos, exercícios interativos e jogos digitais.

As imagens foram realizadas no Centro de Simulação do Instituto de Ensino e Pesquisa São Camilo da Rede de Hospitais São Camilo e no laboratório de enfermagem vinculado centro dos laboratórios de enfermagem em ensino, habilidades, simulação e pesquisa (CELAB) da Escola de Enfermagem da Universidade de São Paulo, com o apoio de câmeras fotográficas Canon modelo G1X e NiKon modelo d7000, respectivamente.

Em virtude da produção de imagens não constituir atividade habitual dos profissionais envolvidos, exigiu maior dedicação e tempo para composição de cenários, adequação de iluminação e captura de imagens. Os recursos humanos que atuaram nesta etapa foram o pesquisador como ator principal e os colaboradores das equipes multiprofissionais de ambos os serviços.

A edição das imagens e a produção das ilustrações foram realizadas pela HIPOCAMPUS (empresa especializada na produção de cursos personalizados em Educação à Distância e seus parceiros) por meio de softwares adotados pela empresa.

O vídeo sobre Desfibrilador Externo Automático (DEA) foi produzido e disponibilizado para uso neste curso pela Enfermeira Doutora Lucia Tobase ${ }^{(38)}$. O vídeo sobre Suporte Básico de Vida foi produzido de acordo com as diretrizes da AHA/2015 pela HIPOCAMPUS em parceria com o Núcleo de Educação em Urgência do Instituto Paulista de Treinamento e Ensino (IPATRE) e disponibilizado para uso neste curso pela Enfermeira Doutora Débora Cristina Alavarce.

Os vídeos em três dimensões (3D) sobre abertura de vias aéreas, inserção de cânula orofaríngea e eletrocardiograma (ECG) fazem parte do Projeto Homem Virtual da disciplina de Telemedicina, da Faculdade de Medicina da Universidade de São Paulo (FMUSP), que tem parceria com a Escola de Enfermagem da USP.

O Projeto Homem Virtual é um método de comunicação dinâmica e dirigida, representado em terceira dimensão. Permite fornecer informações especializadas em grande quantidade de modo objetivo, interativo e agradável para explicar estruturas e o funcionamento do corpo humano e auxiliar o aprendizado por facilitar o entendimento em relação ao tema 
específico $^{(98)}$. Os recursos computacionais gráficos em 3D potencializam a apreensão do conhecimento por meio de habilidades espaciais e visuais dos processos fisiológicos e procedimentais $^{(51)}$.

Foram selecionados, ainda, textos para leitura complementar e vídeos por meio de busca bibliográfica na internet.

O processo avaliativo foi desenvolvido de acordo com os conceitos de:

- Avaliação diagnóstica: estruturada por meio de questionário no início do curso com trinta e seis questões, sendo quatro para cada tema abordado nas nove unidades de aprendizagem. A finalidade é investigar o domínio dos participantes quanto aos temas e, dessa maneira, nortear os seus estudos. Nessa fase, os participantes do curso têm a oportunidade de identificar suas lacunas de conhecimentos, verificar quais temas precisam ser revisados integralmente - ou em partes - e reconhecer suas reais necessidades de aprimoramento;

- Avaliação formativa: realizado por meio de exercícios e jogos digitais educacionais com feedback ao longo do curso que intencionam contribuir na construção e apropriação do conhecimento de maneira dinâmica e divertida;

- Avaliação somativa: constituída pelo teste final, que foi elaborado no formato de simulação virtual de atendimento de PCR no SAV. Foram propostos exercícios sobre os pontos chaves do atendimento de PCR, os quais se referem ao reconhecimento rápido da situação com tomada de decisão assertiva, realização da sequência de intervenções por prioridade, identificação do ritmo cardíaco e conduta para cada caso, além dos medicamentos recomendados e vias de administração prioritárias, do manejo de vias aéreas e dos cuidados pós-PCR. Este exercício constitui-se em tarefa obrigatória no curso e requer desempenho de $84 \%$ para obtenção do certificado, seguindo os padrões avaliativos da AHA.

As questões que compõem os instrumentos de avaliações diagnóstica, formativa e somativa foram elaboradas pela pesquisadora com base nos objetivos educacionais e nos conteúdos abordados no curso, bem como avaliadas quanto ao conteúdo por três especialistas na área de urgência e emergência, sendo realizadas as alterações sugeridas. Posteriormente, outras duas especialistas da mesma área revisaram e aprovaram todas as questões. 
Essa fase consistiu em momento ímpar da criação do curso, que exigiu ampla experiência da pesquisadora relacionada à temática, dedicação e sincronia com a equipe de desenvolvedores, bem como intensa criatividade e reflexão para representar o conhecimento teórico/prático sobre a RCP no formato on-line.

\subsubsection{Implementação}

Esta fase consistiu na publicação do material didático no ambiente virtual de aprendizagem Moodle ${ }^{\circledR}$ e na configuração das ferramentas e recursos tecnológicos educacionais, possibilitando o acesso ao curso pela internet por meio de diferentes browsers e dispositivos tecnológicos. $\mathrm{O}$ acesso ao curso foi disponibilizado aos avaliadores e, posteriormente, poderá ser implementado para o público-alvo.

\subsubsection{Avaliação}

Nesta fase, foi realizada a revisão geral do conteúdo, do desenho e dos componentes educacionais e tecnológicos do curso on-line sobre SAV em PCR, verificado o funcionamento dos elementos de animação, dos ícones, dos botões e dos exercícios interativos e identificadas as falhas nos níveis de análise, de desenho, de desenvolvimento e de desempenho.

Na perspectiva do DIC, a avaliação ocorre durante todo o processo de construção do curso, desde a concepção até a implementação e finalização, porém, nesta última etapa, é importante para realização dos ajustes finais.

As características recursivas e dinâmicas do DIC possibilitaram retorno constante às diversas fases do processo de criação do curso on-line, com reformulação e revisão continua do conteúdo, das imagens, das estratégias, dos exercícios e da disposição das telas e das informações.

Após essa primeira análise e correções, o curso no AVA foi liberado para avaliação da qualidade na perspectiva dos enfermeiros especialistas das áreas de urgência e emergência e educação on-line. 


\subsection{CONSIDERAÇÕES ÉTICAS}

O projeto foi aprovado pelo Comitê de Ética em Pesquisa da EEUSP, sob o processo $\mathrm{n}^{\circ}$ 1.667.269/2016 e identificador CAAE 54831516.5.0000.5392, em 03 de agosto de 2016 (ANEXO B).

Os participantes do estudo foram convidados a avaliar o curso, sendo esclarecidos sobre os objetivos e as finalidades da pesquisa, bem como sobre o sigilo, a privacidade e o anonimato de todos os participantes, assegurando os aspectos éticos do estudo por meio do Termo de Consentimento Livre e Esclarecido (TCLE) de participação do estudo, conforme rege a Resolução CNS/MS 466/2012, que regulamenta a ética em pesquisa envolvendo seres humanos no Brasil.

Os enfermeiros que participaram voluntariamente da pesquisa receberam, por meio eletrônico, o endereço do link de acesso ao instrumento de avaliação e aceitaram participar da pesquisa ao clicar em "concordo".

\subsection{ANÁLISE DOS DADOS}

Os dados obtidos referentes à avaliação dos especialistas foram registrados e compilados em planilhas utilizando-se o software Excelß, submetidos a análise estatística por meio do software Statistical Package for the Social Sciences ${ }^{\circledR}$ (SPSS), versão 22, e apresentados na forma de tabelas com os valores da média e do desvio padrão. Frequências absolutas e relativas foram utilizadas para idade, sexo, titularidade, tempo de formação e de experiência nas áreas de urgência e emergência e educação on-line. 



\section{RESULTADOS}

\subsection{CURSO ON-LINE SOBRE SUPORTE AVANÇADO DE VIDA EM PARADA CARDIORRESPIRATÓRIA}

O curso foi configurado e disponibilizado na página do GEPETE hospedada na plataforma Moodle® 3.1 no endereço eletrônico http://gepete.com.br/login/index.php. O desenho do curso foi estruturado a partir da matriz de design instrucional que apresenta o objetivo geral do curso, as unidades de aprendizagem e seus respectivos temas, bem como os objetivos educacionais específicos, os conteúdos, os objetos de aprendizagem, as estratégias pedagógicas e os critérios de avaliação.

Para tanto foram definidas nove unidades de aprendizagem seguindo o algoritmo de atendimento em PCR do adulto, conforme Figura 3.

- Suporte Básico de Vida (SBV)

- Monitorização Cardíaca

- Análise do Ritmo Cardíaco

- Desfibrilação

- Acesso Intravascular

- Medicamentos Recomendados na PCR

- Manejo de Via Aérea Avançada

- Causas Reversíveis de PCR

- Cuidados Pós -PCR

A unidade de aprendizagem Suporte Básico de Vida foi incluída no curso por constituir intervenções a serem realizadas durante a RCP e serem fundamentais ao processo de ensino aprendizagem sobre o atendimento à PCR. A estratégia utilizada confere dinamicidade na 
revisão sobre as manobras de reanimação cardiopulmonar no suporte básico de vida e inclui exercícios com feedback em diversos momentos da apresentação do conteúdo.

Figura 3 - Algoritmo de Suporte Avançado de Vida em PCR no Adulto.

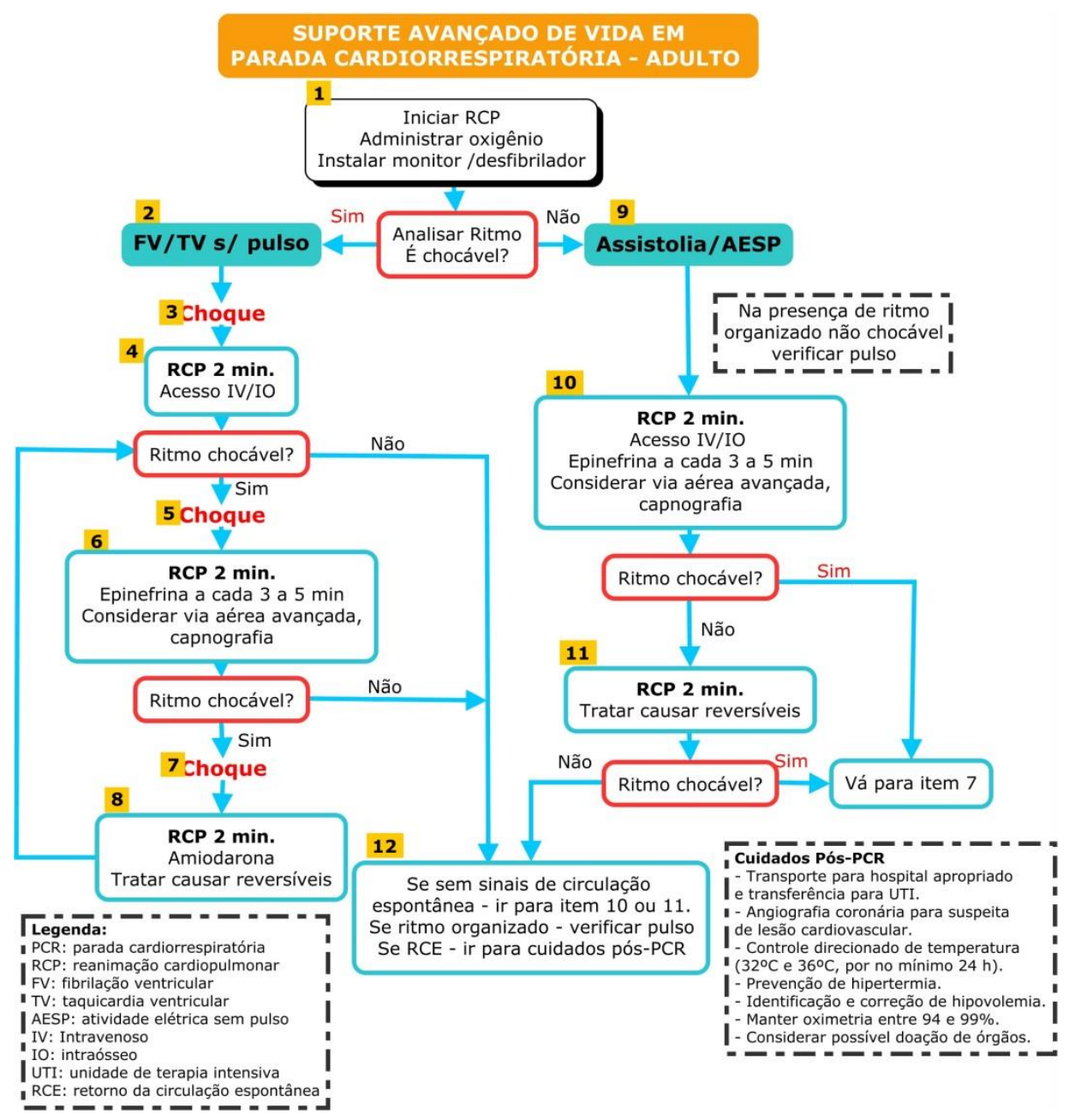

Fonte: Adaptado das Diretrizes da AHA / 2015.

Os objetivos educacionais foram elaborados com base na Taxonomia de Bloom ${ }^{(97)}$ e estão relacionados às ações do participante e à avaliação da aprendizagem. A carga horária foi estimada a partir das unidades de aprendizagem propostas com duração de 9 semanas, equivalendo a aproximadamente 4 horas semanais de estudos, totalizando 36 horas. $\mathrm{O}$ acesso do participante ao AVA ocorre por meio do preenchimento do nome do usuário e da senha pessoal na tela de identificação (Figura 4). 
Figura 4 - Tela de identificação para acesso ao curso.

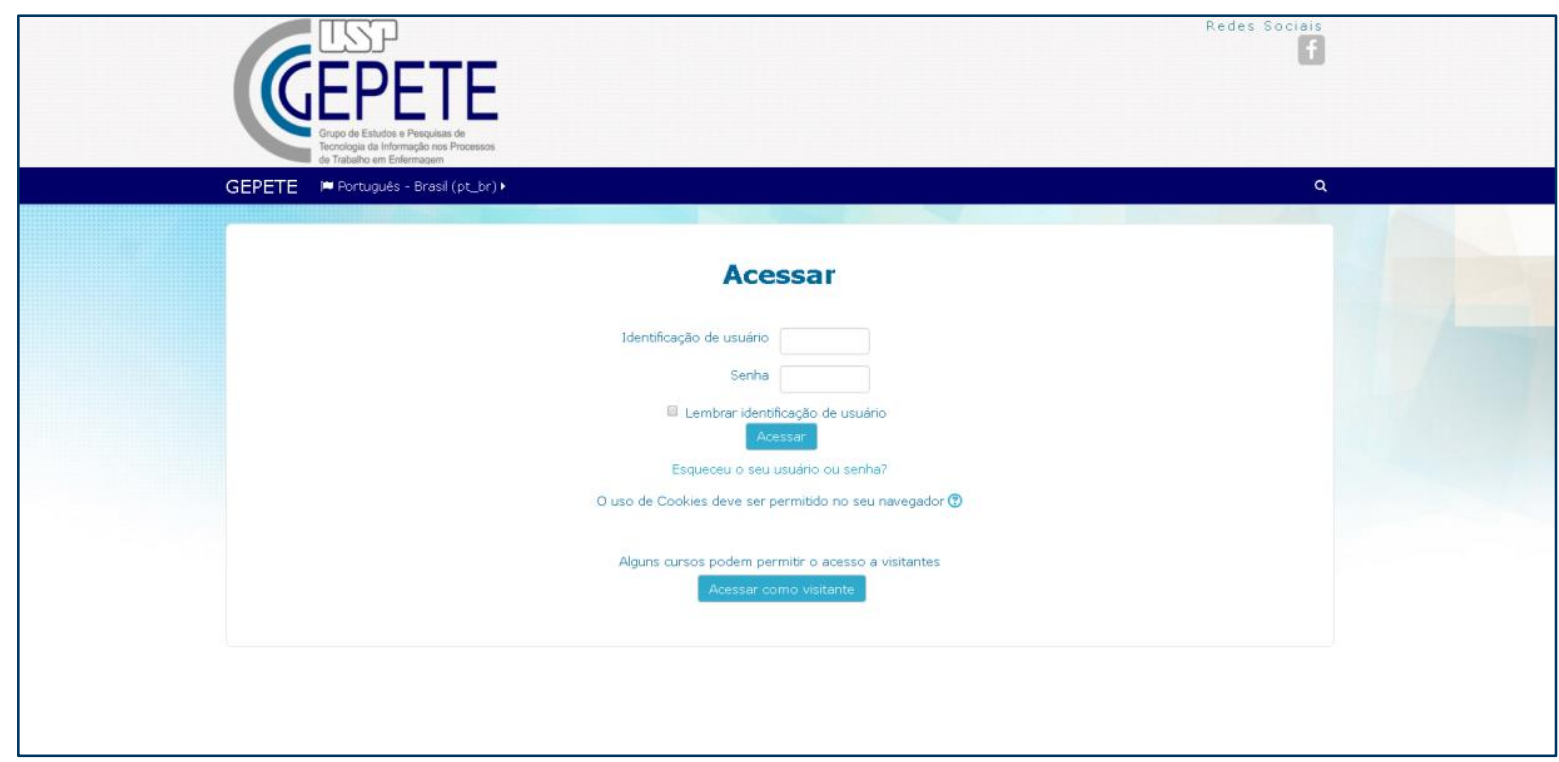

Fonte: Dados da pesquisa.

Na tela inicial do curso foram dispostos os ícones Tutorial, Avaliação Diagnóstica, Plano de Curso, Dúvidas e Certificado, conforme Figura, que apresenta informações essenciais para o estudo do participante (Figura 5).

Figura 5 - Tela inicial do curso.

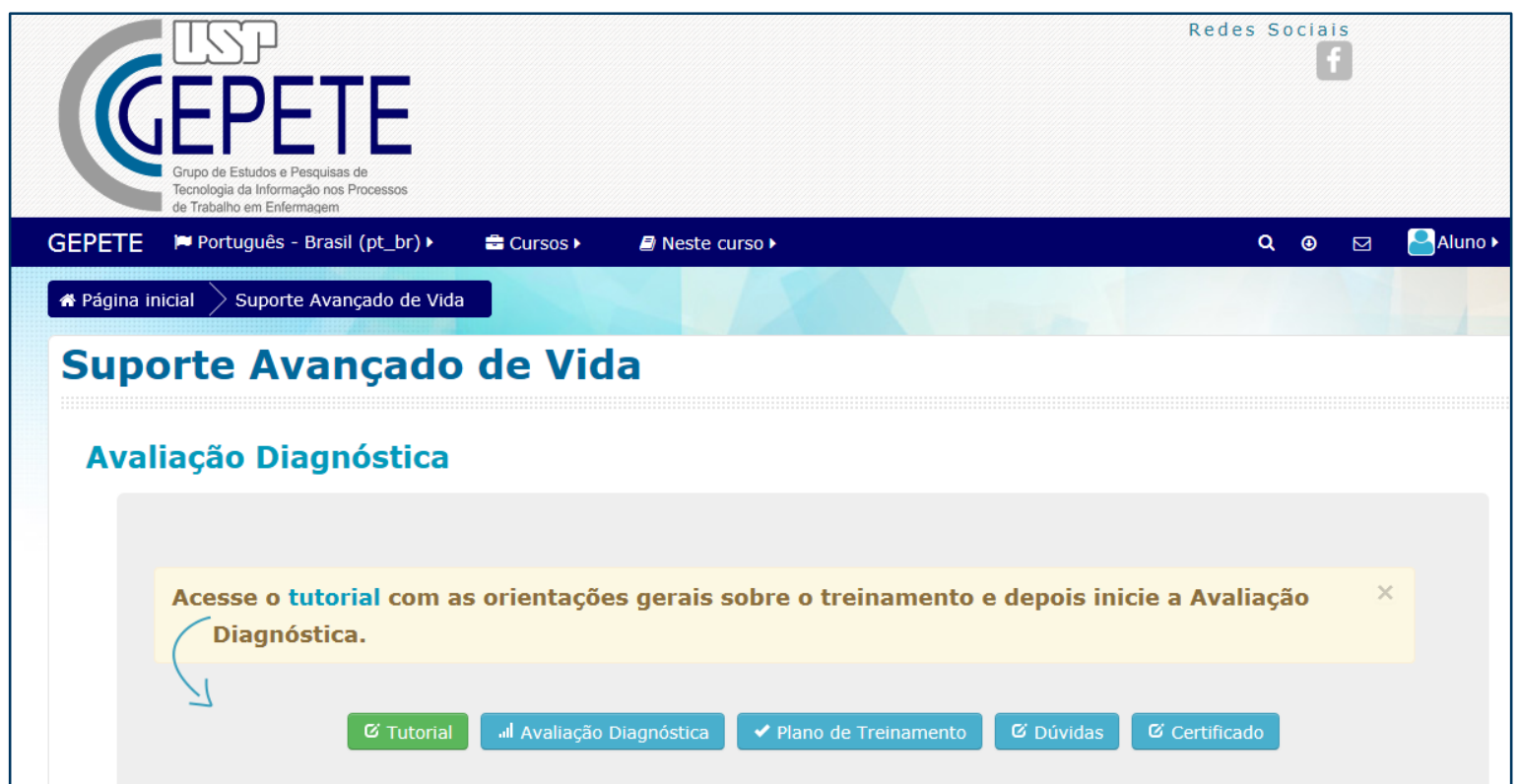

Fonte: Dados da pesquisa. 
Para acesso e navegação dos participantes no ambiente virtual de aprendizagem, foram elaboradas orientações gerais e informações sobre os comandos e o funcionamento dos ícones no formato de Tutorial, bem como a rota de navegação (Figura 6) que ilustra os caminhos a serem percorridos durante o processo de aprendizagem pelas unidades de estudo. No tutorial, são apresentados, ainda, o objetivo educacional geral do curso e as estratégias de avaliação diagnóstica, formativa e somativa. Essas informações podem ser obtidas ao clicar no ícone ou no hiperlink Tutorial.

Figura 6 - Rota de navegação nas unidades de aprendizagem.

\section{Diagrama da Rota de Aprendizagem}

Olá, esta rota irá guiá-lo pelo curso orientando seu percurso de aprendizagem. Boa navegação!!

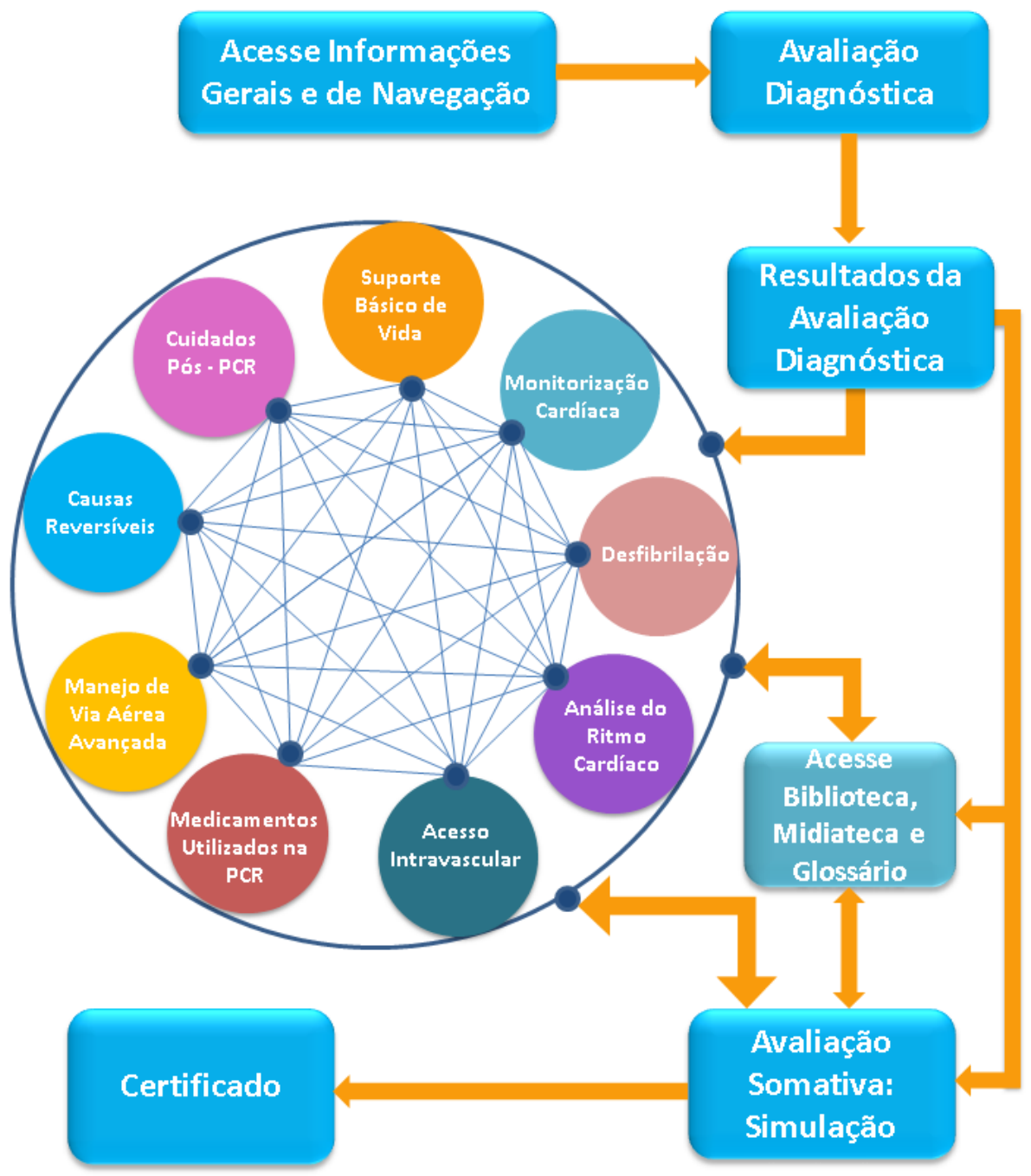

Fonte: Dados da pesquisa. 
Para iniciar o curso, é necessário realizar a atividade denominada Avaliação Diagnóstica (Figura 7), por meio de um questionário constituído de trinta e seis questões, sendo quatro para cada tema abordado nas nove unidades de aprendizagem. Neste momento, o questionário tem a finalidade de oferecer ao participante a autoavaliação sobre o conhecimento da temática do curso, permitindo identificar lacunas de conhecimentos, verificar quais temas precisam ser revisados integralmente ou, em partes, e, dessa maneira, nortear os seus estudos.

Figura 7 - Tela inicial do curso com a Avaliação Diagnóstica.

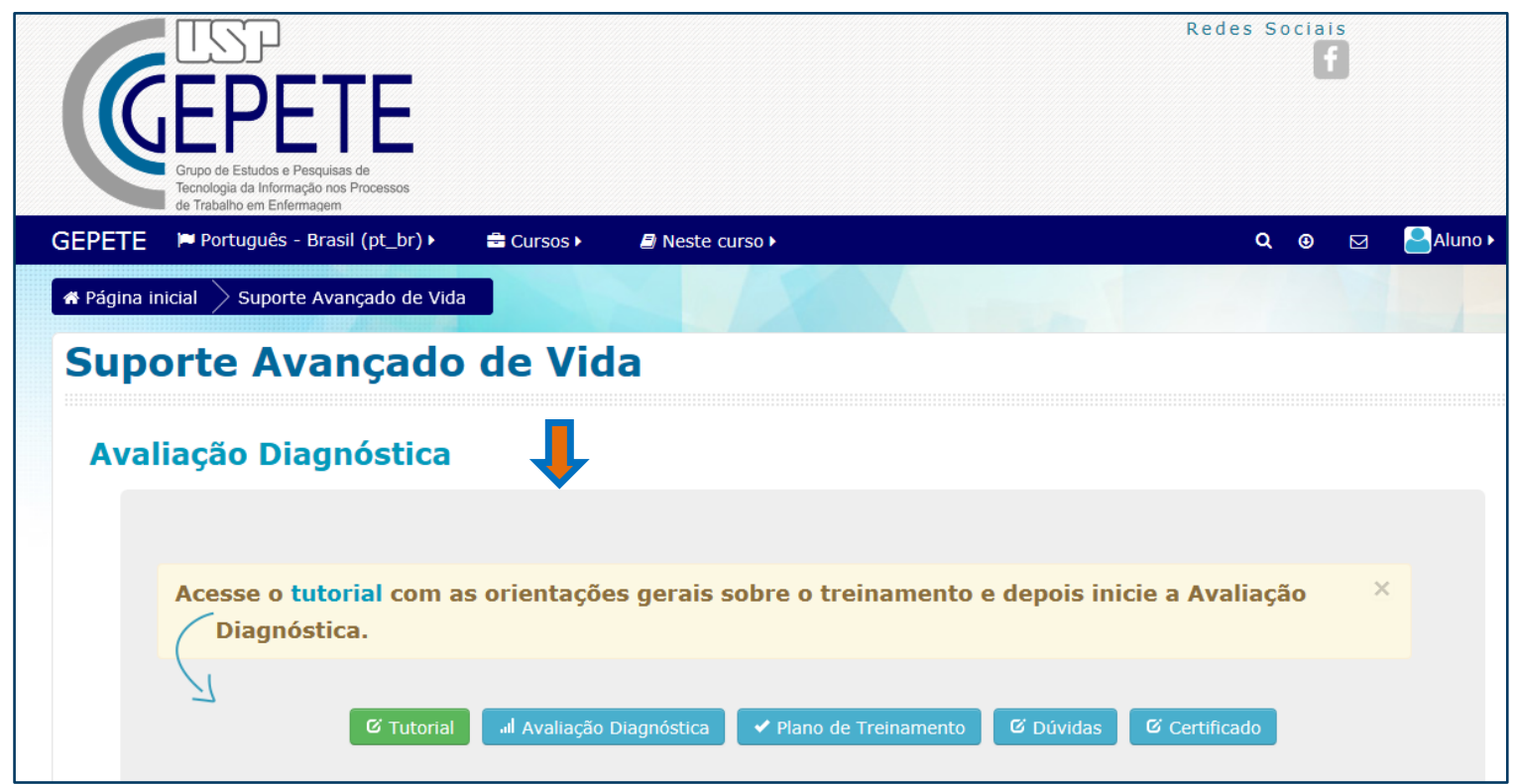

Fonte: Dados da pesquisa.

As questões possuem cinco alternativas (Figura 8), sendo apenas uma correta que pode ser selecionada com um clique. Ao finalizar o questionário, o participante clica no botão Enviar e, em seguida, receberá o feedback com o resultado de seu desempenho no exercício. 
Figura 8 - Modelo de questão da avaliação diagnóstica.

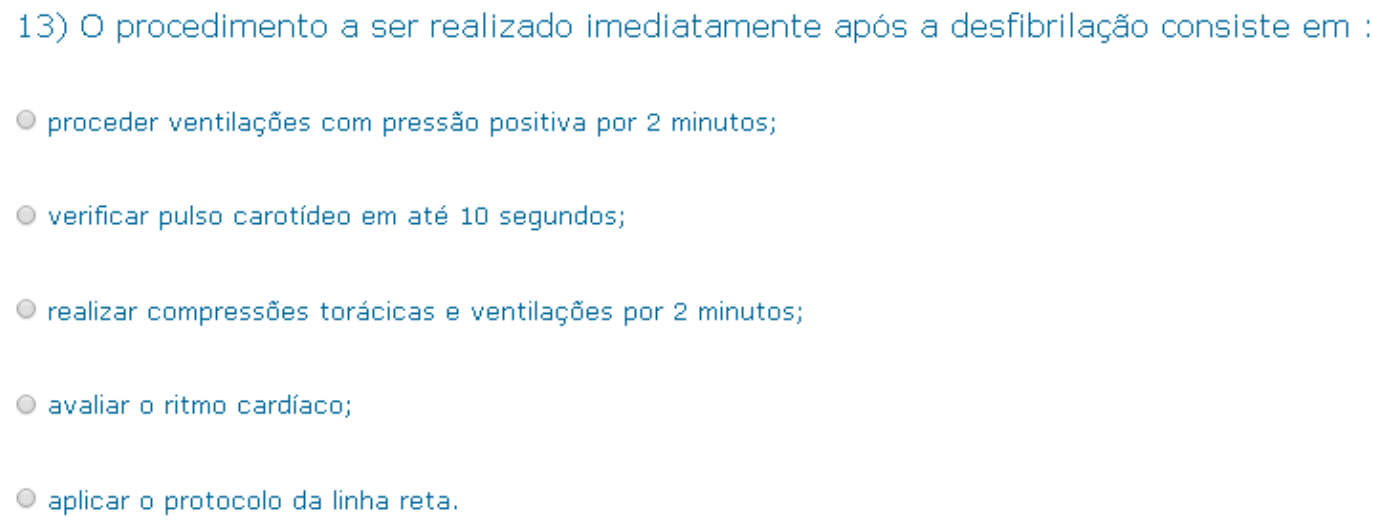

Autores: Hipocampus, Edenir A. S. Tomazini; 2016.

O ícone de acesso ao Plano de Curso disponibiliza a tela com o resultado da avaliação diagnóstica e a sugestão das unidades de aprendizagem a serem estudadas. De acordo com a performance do participante na avaliação diagnóstica, são sugeridos diferentes caminhos a serem percorridos, tais como:

- Curso completo: é recomendado quando o participante apresentar desempenho $<84 \%$ na avaliação diagnóstica de todas as unidades de aprendizagem;

- Unidade de aprendizagem específica: é indicada quando o enfermeiro atingir $\leq 84 \%$ de acerto na avaliação diagnóstica de uma unidade de aprendizagem específica (Figura 9);

- Simulação virtual: é sugerida quando o participante atingir $84 \%$ de acerto nas questões da avaliação diagnóstica. 
Figura 9 - Tela com a apresentação dos temas das unidades de aprendizagem sugeridos para estudo de acordo com o resultado da avaliação diagnóstica.

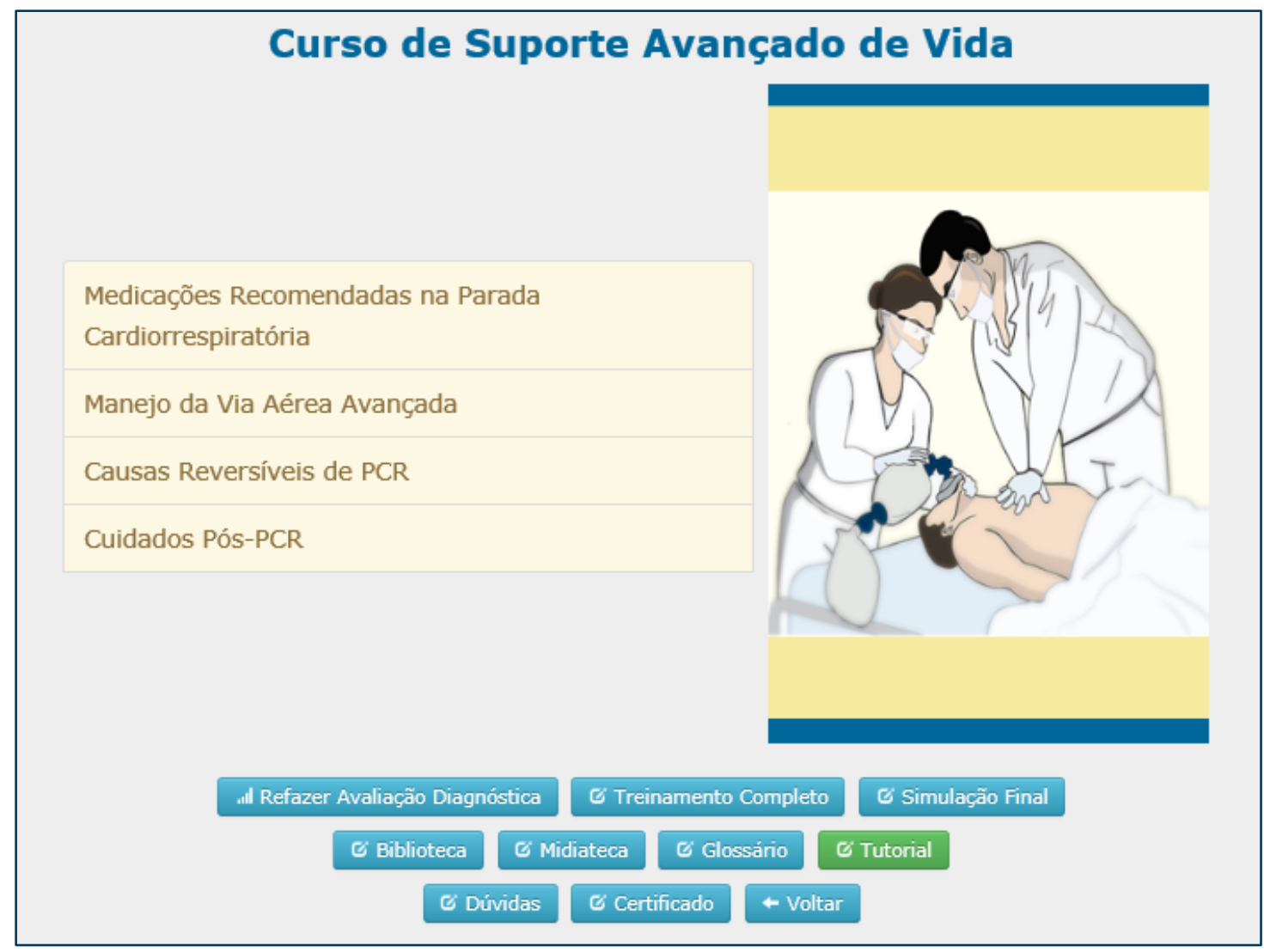

Fonte: Dados da pesquisa.

Na tela do Plano de Curso, ainda estão disponíveis vários ícones como o canal de dúvidas, certificado, biblioteca, a midiateca, o glossário, a simulação final, a tela que disponibiliza o curso completo e o ícone para refazer a avaliação diagnóstica caso o participante deseje.

O ícone Dúvidas consiste no canal de comunicação com o professor/tutor do curso, bastando, para isto, apenas preencher o formulário e, em seguida, pressionar o botão Enviar para que a mensagem seja encaminhada diretamente ao $e$-mail do professor/tutor.

O ícone Certificado possibilita acessar o certificado ao obter $84 \%$ de acertos na simulação final.

Os ícones Biblioteca e Midiateca permitem acesso aos materiais didáticos de apoio e complementares, tais como as diretrizes nacionais e internacionais para o atendimento de PCR, artigos científicos, infográfico sobre o Suporte Básico de Vida e textos de apoio sobre a 
temática, links de páginas da Web, assim como vídeos, além de outros conteúdos relacionados à temática. Nestes espaços, o participante tem acesso livre e pode fazer download do material disponível a qualquer momento, esclarecer dúvidas e ampliar seus conhecimentos.

No curso, foi construído, ainda, Glossário com a definição de termos menos conhecidos ou utilizados rotineiramente. Este recurso objetivou auxiliar na fixação de conceitos e conteúdos e permitir a construção individual ou coletiva do conhecimento referente aos vocábulos.

As unidades de aprendizagem permanecem ocultas até a conclusão da avaliação diagnóstica e, posteriormente, o participante tem liberdade de interagir com o curso como desejar. Nesse sentido, em cada unidade a interatividade com os objetivos educacionais, o conteúdo, os exercícios de fixação da aprendizagem, os jogos digitais, o material complementar e de apoio, o glossário e as referências podem ser realizadas quantas vezes forem necessárias.

Ao final de cada unidade de aprendizagem, após breve síntese do conteúdo, é disponibilizado link para os jogos digitais e apresentadas as referências utilizadas.

As unidades de aprendizagem contam com vários botões e ícones para auxiliar o participante na navegação e na identificação de pontos de destaque do conteúdo. No Quadro 1 estão descritos o significado de cada ícone:

Quadro 1 - Representação dos ícones.

\begin{tabular}{|c|c|}
\hline Ícones & Significados \\
\hline Anterior & Retornar à página Anterior \\
\hline Próxima & Seguir para Próxima página \\
\hline Retornar $\rightarrow$ Retornar para página inicial do \\
curso
\end{tabular}




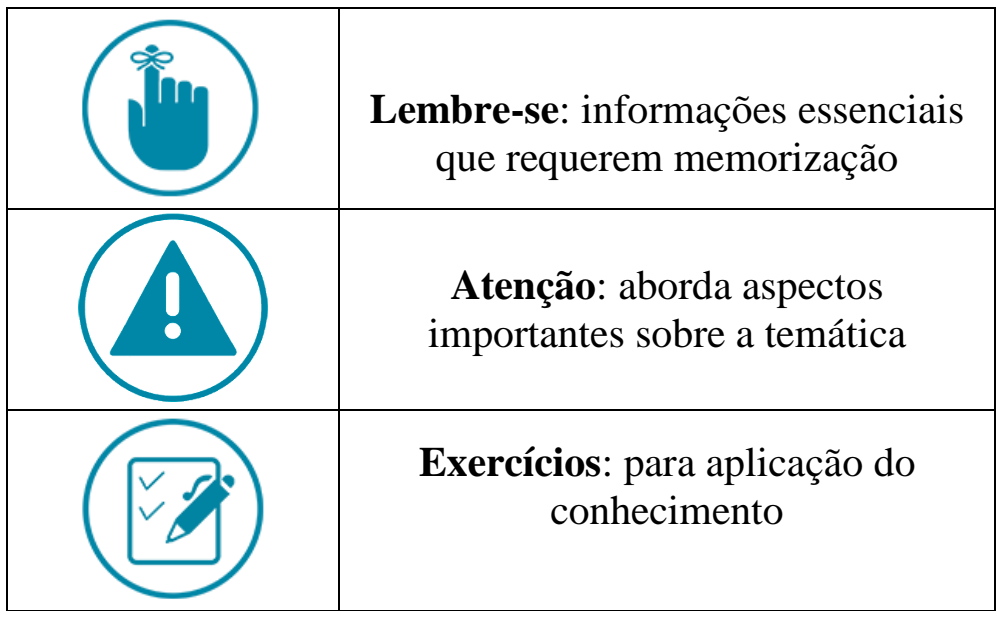

Fonte: Dados da pesquisa.

As unidades de aprendizagem foram estruturadas utilizando o recurso Lição do Moodle ${ }^{\circledR}$ adotando-se hipertextos, vídeos, exercícios de aprendizagem e jogos digitais referentes aos assuntos apresentados. Nessa organização, buscou-se apoiar o participante a identificar conceitos e conhecimentos que podem estar presentes em sua estrutura cognitiva. Para exemplificar, na unidade sobre SBV, utiliza-se vários vídeos que reavivam a realização de procedimentos como a inserção da cânula orofaríngea, a ventilação com bolsa-válvula-máscara, o uso do DEA (Figura 10) e as manobras de SBV.

Figura 10 - Vídeo sobre o Desfibrilador Externo Automático.

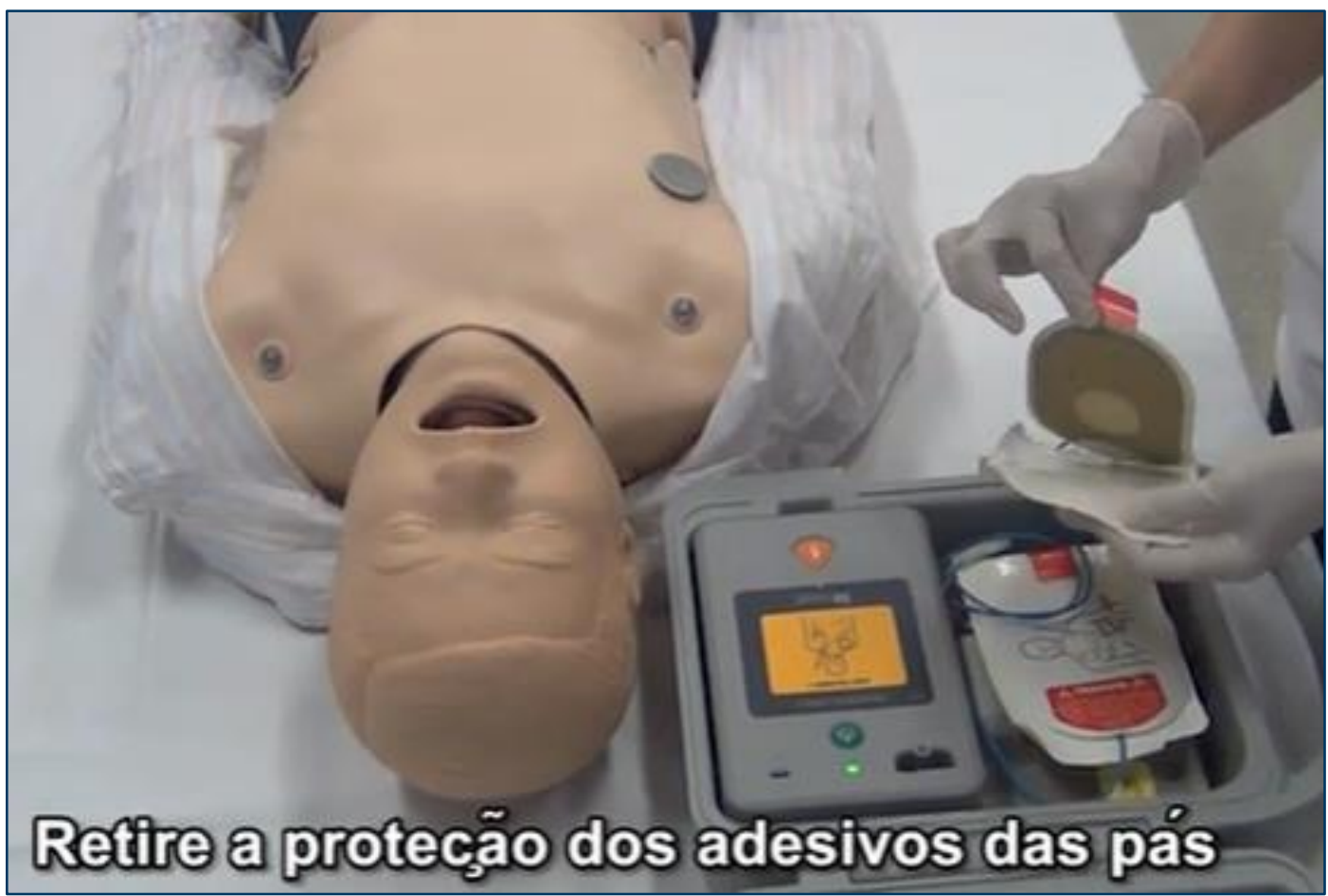

Fonte: Tobase, 2016. 
Os hipertextos remetem os participantes para leituras obrigatórias e complementares que se encontram dentro do mesmo documento ou para outros conteúdos, páginas ou unidades de aprendizagem (Figuras 11 e 12). Esse recurso foi adotado com a finalidade de permitir aprofundamento do assunto de maneira flexível, dinâmica e não sequencial.

Figura 11 - Exemplo de hipertexto na mesma página.

Lembre -se!! O parecer do COREN-SP CAT N 030/2010 atualizado em 11/ parada cardiorrespiratória e enfatiza que:

[..] cabe ao enfermeiro, responsável exclusivamente pelo planejamento como por atender, privativamente, ao paciente grave com risco de morte 7.498/86), e à sua equipe assistir aos pacientes, oferecendo ventilação e assim, estes profissionais devem adquirir habilidades que os capacitem a equipe de Enfermagem deve ter conhecimento e domínio do manuseio do: de emergência, bem como estar inserida em programas periódicos de cap reanimação.

Leia na íntegra, o parecer do COREN-SP CAT № 030/2010 clicando aqui

Fonte: Dados da pesquisa.

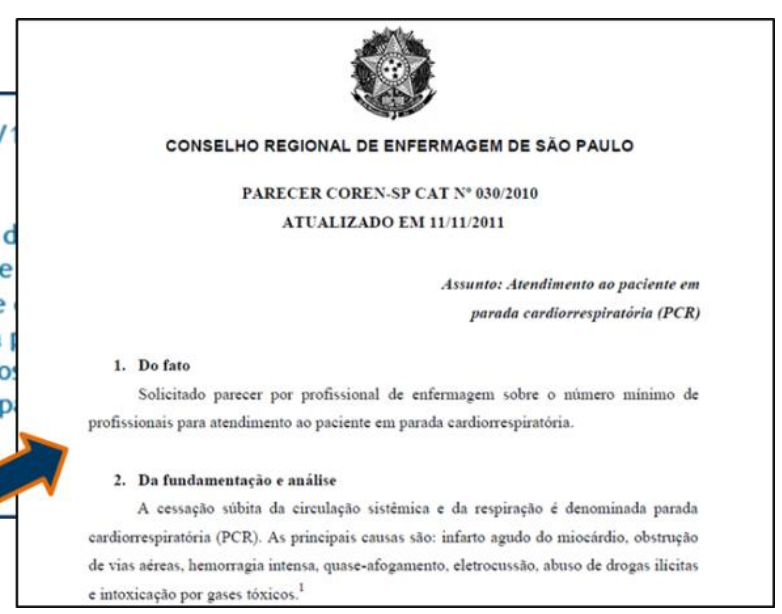

Figura 12 - Exemplo de hipertexto com link a outra página.

\section{Análise do Ritmo Cardíaco: Chocável ou não?}

Revisão e Atualização do Protocolo Mundial para A tendimento de Parada Cardiorrespiratória

OBJETIVOS EDUCACIONAIS

Ao concluir a unidade de aprendizagem, você deverá ser capaz de:

- Distinguir os ritmos cardíacos associados à parada cardiorrespiratória (PCR) e associar a abordagem terapêutica específica;

- Listar os três passos para realização do protocolo da linha reta.

Nessa unidade vamos abordar os principais ritmos cardíacos da PCR.

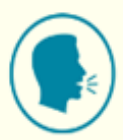

Após realizarmos a monitorização cardíaca, o próximo passo é a análise do ritmo.

Vamos conhecer os ritmos on veis e os não chocáveis, com suas respectivas

características e condutas.

Fonte: Dados da pesquisa. 
Os vídeos disponibilizados no curso tiveram como objetivo apoiar a aprendizagem e foram selecionados pela pesquisadora de maneira rigorosa, adotando como critérios a atualização, clareza, concisão e relevância ao contexto. As temáticas dos vídeos foram sobre ECG, abertura de vias aéreas, inserção de cânula orofaríngea e máscara laríngea, intubação orotraqueal, uso do DEA e síntese das manobras de SBV.

O vídeo ECG Projeto Homem Virtual demonstra o funcionamento do sistema de condução do impulso elétrico do coração, por meio de recursos da computação gráfica em 3D, objetivando auxiliar o participante na revisão e entendimento dos ritmos cardíacos (Figura 13).

Figura 13 - Vídeo sobre ECG do Projeto Homem Virtual.

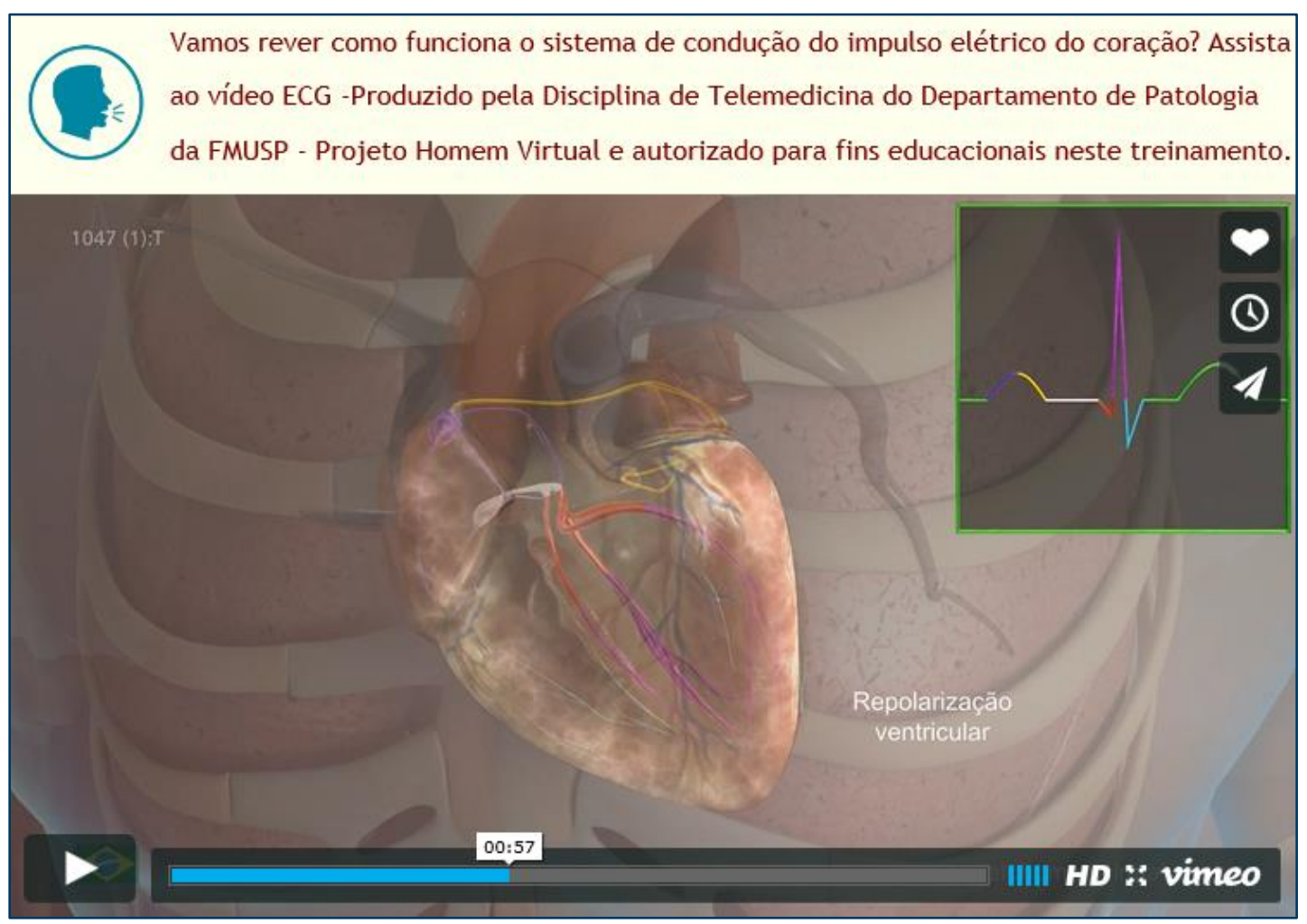

Fonte: Dados da pesquisa.

Os exercícios de aprendizagem - que constituem parte da avaliação formativa - foram estruturados no decorrer e ao final da apresentação do conteúdo, por meio de questões de associação ou de múltipla escolha com uma ou mais opções de resposta correta e feedback imediato para cada alterativa. Os exercícios com respostas objetivas oferecem ao aprendiz, 
rápido retorno de seu desempenho, pois fornecem feedback imediato após o envio de cada resposta.

Quando o participante assinala a alternativa correta, recebe o feedback com estímulo positivo de congratulações (Figura 14), seguido da ênfase do conteúdo em relação a resposta correta e da justificativa quanto às incorretas. Mediante resposta incorreta, recebe o feedback que a resposta está errada e que há dois caminhos, Tentar novamente ou Seguir para próxima questão (Figura 15).

Figura 14 - Feedback das respostas corretas.

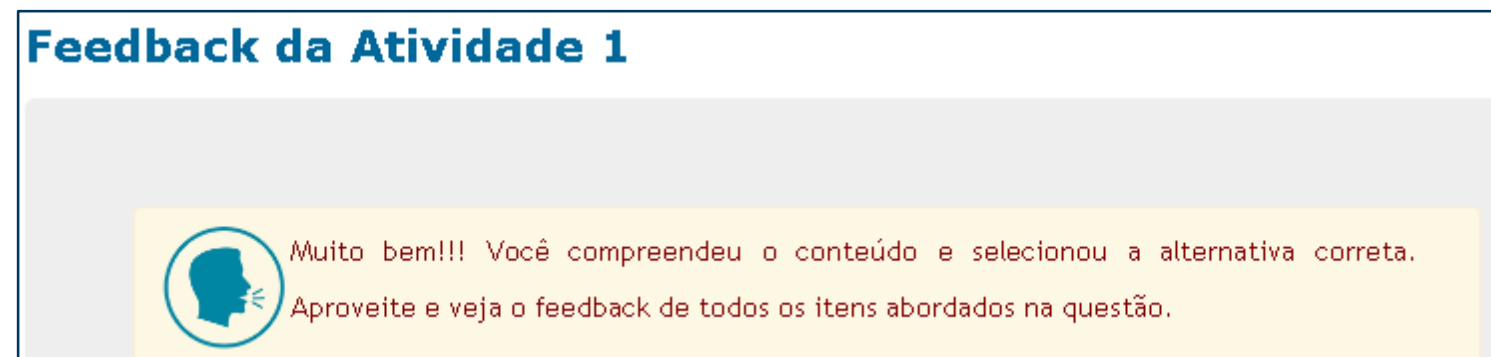

Fonte: Dados da pesquisa.

Figura 15 - Feedback das respostas incorretas.

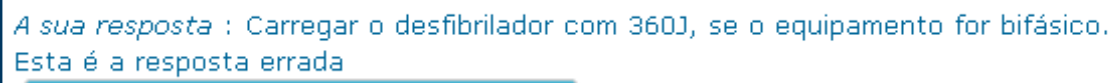

Fonte: Dados da pesquisa.

Ao final de todas as unidades de aprendizagem, está disponível breve síntese do conteúdo abordado e o acesso, por meio do ícone Diversão, aos exercícios interativos estruturados por jogos digitais do tipo nave e quebra-cabeça. As orientações para acessar os jogos digitais educacionais foram descritas em um tutorial específico.

O jogo digital do tipo nave foi inspirado no clássico "Space Invaders". Nesse exercício, o participante utiliza a nave para lançar mísseis nas respostas de 10 questões curtas e objetivas sobre as temáticas de suporte básico de vida (SBV), desfibrilação, medicamentos recomendados 
na PCR, manejo de via aérea avançada e causas reversíveis de PCR. Cada questão apresenta quatro respostas, sendo apenas uma correta. Ao se atingir a resposta correta, recebe-se a pontuação e mantém-se as vidas e, se atingir a resposta incorreta ou for atingido pelo míssil oponente, perderá pontos e vidas. O jogador tem três vidas e utiliza as teclas SETAS para a DIREITA, ESQUERDA, CIMA, BAIXO, para mover a nave e enviar os mísseis para as respostas com a barra de espaço do computador. Na Figura 16, pode ser exemplificado o jogo digital referente ao tema Causas Reversíveis de PCR.

Figura 16 - Imagem do jogo digital do tipo Nave referente a unidade de aprendizagem Causas Reversíveis de PCR.

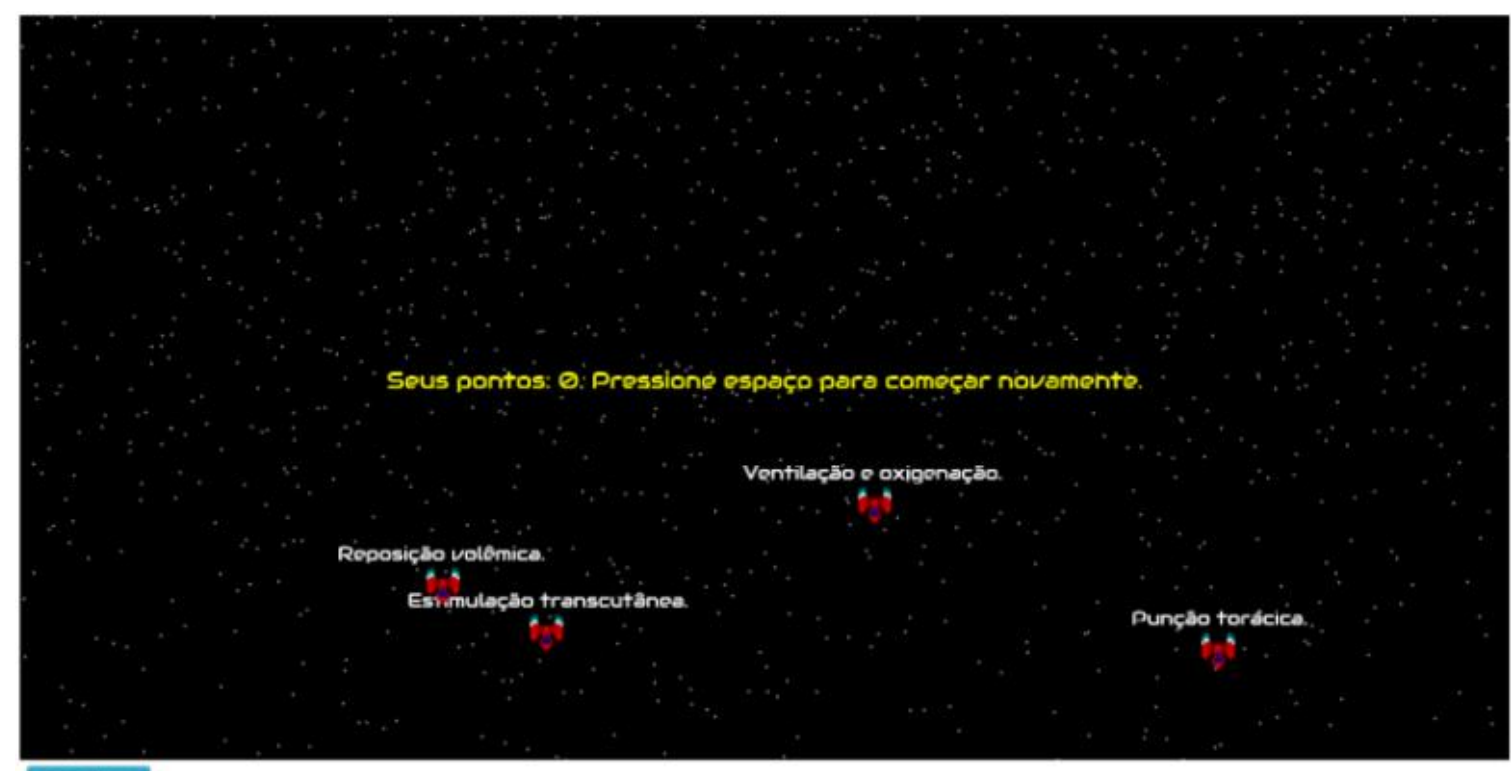

Tels chess Gsound

Fonte: Dados da pesquisa.

Para os jogos digitais do tipo quebra-cabeça, foram produzidas imagens que abordam sinteticamente o conteúdo sobre as temáticas monitorização cardíaca, análise do ritmo cardíaco, acesso intravascular e cuidados pós - PCR. Para iniciar o jogo, é necessário mover as peças do quebra-cabeça até formar a imagem correta. A Figura 17 está exemplificando o jogo digital com o tema Análise do Ritmo Cardíaco. 
Figura 17 - Imagem do jogo digital do tipo quebra-cabeça referente a unidade de aprendizagem Análise do Ritmo Cardíaco.

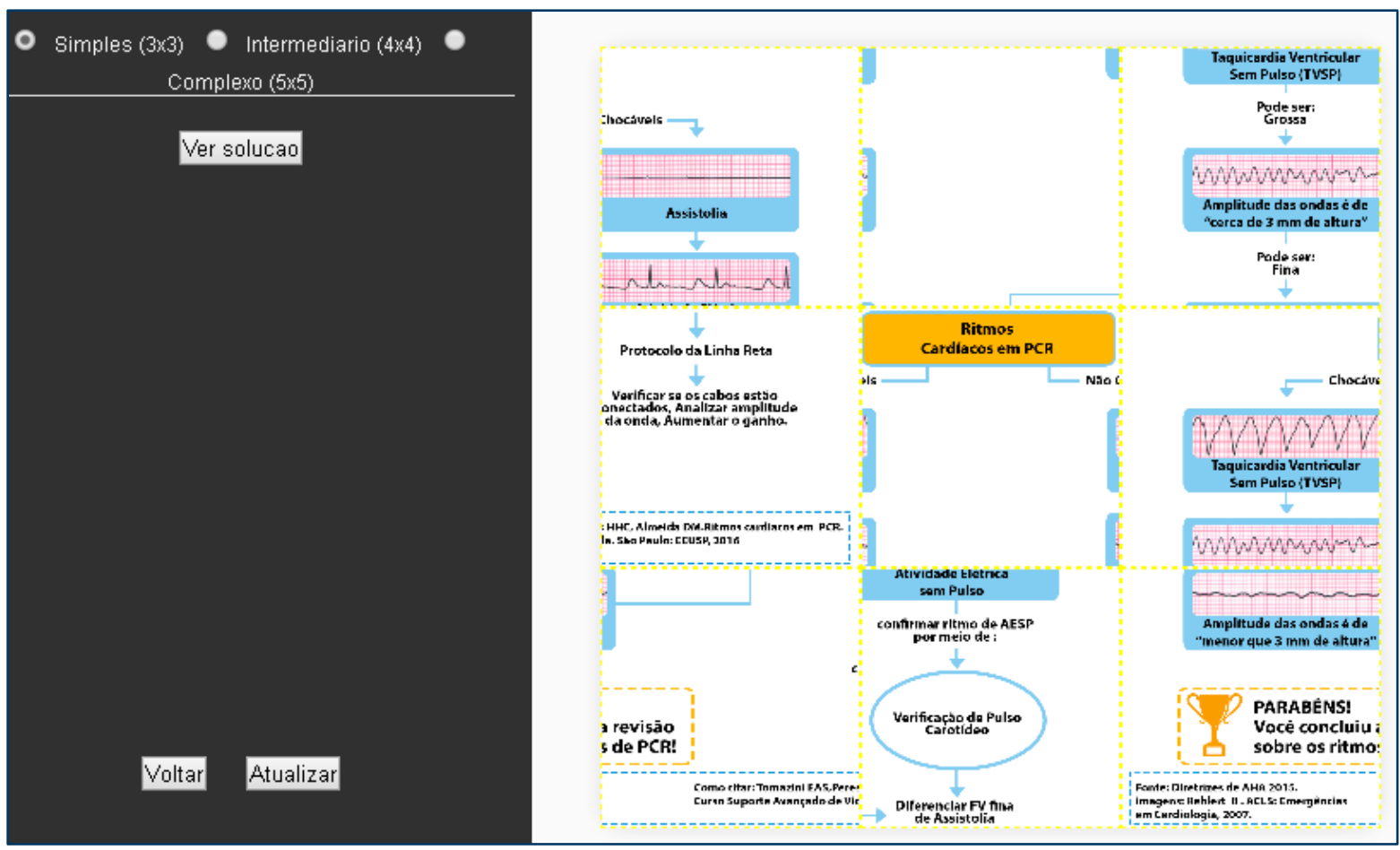

Fonte: Dados da pesquisa.

Na avaliação somativa, foi utilizada a estratégia da simulação virtual onde o participante é convidado a salvar o paciente David, por meio da resolução de dois casos clínicos que apresentam as condições de um paciente adulto em PCR e as manobras de SAV recomendadas. Para o acesso a simulação, é necessário selecionar na tela a opção modalidade normal e clicar em Entrar (Figura 18). 
Figura 18 - Tela de acesso à simulação virtual.

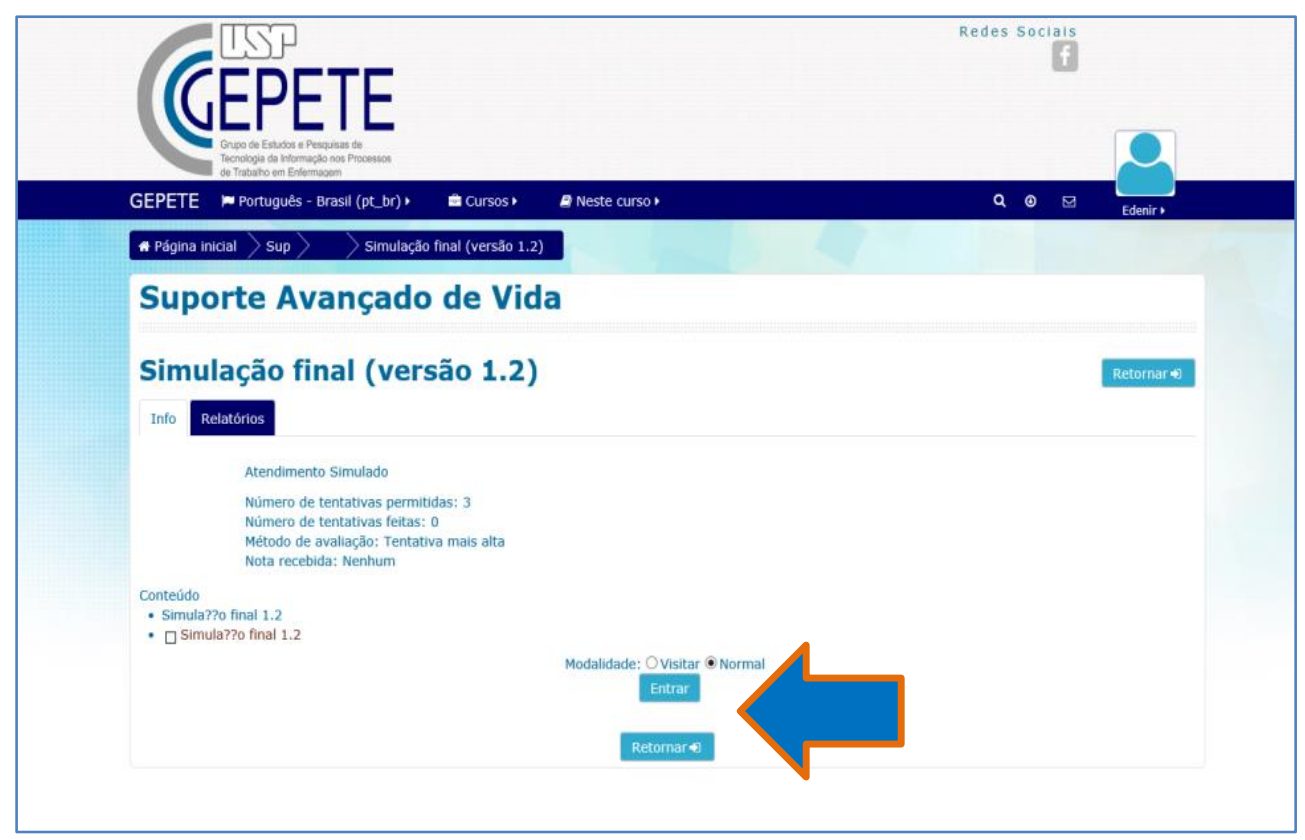

Fonte: Dados da pesquisa.

A tela inicial da simulação está configurada com a ilustração que representa o curso online sobre SAV e com os botões que permitem a navegação pelo exercício (Figura 19).

Figura 19 - Tela inicial da simulação virtual.

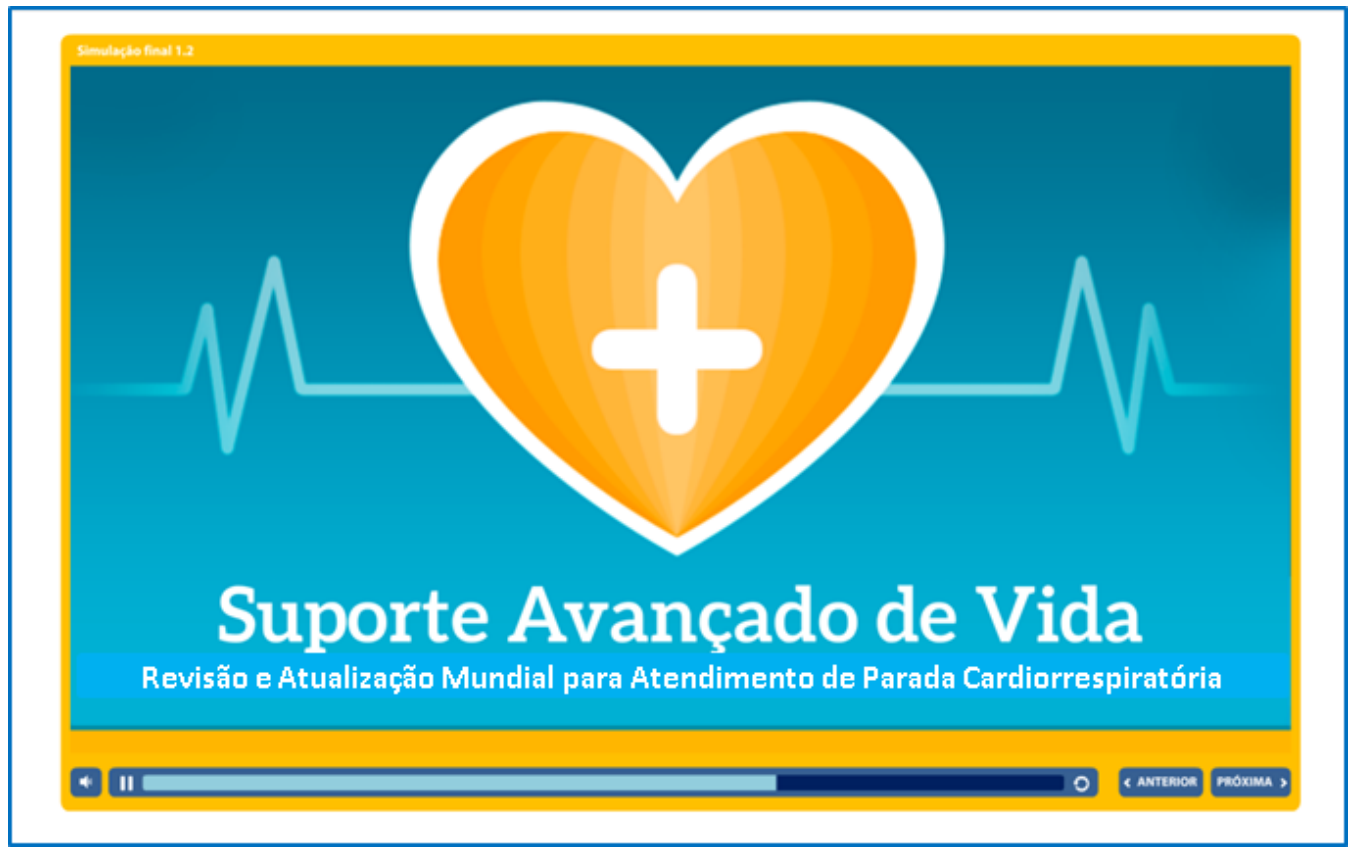

Fonte: Dados da pesquisa. 
Ao selecionar de forma livre qualquer um dos casos, o participante recebe orientações sobre a realização dos exercícios por meio de um avatar feminino (Figura 20), com aspecto de adulto jovem, trajando roupas que lembram o uniforme típico de enfermeiros (jaleco branco e roupas azul). A simulação virtual foi desenvolvida, objetivando criar a sensação de acompanhamento e contextualização do conteúdo, promovendo diálogo e interação com o participante.

Figura 20 - Tela com apresentação do avatar.

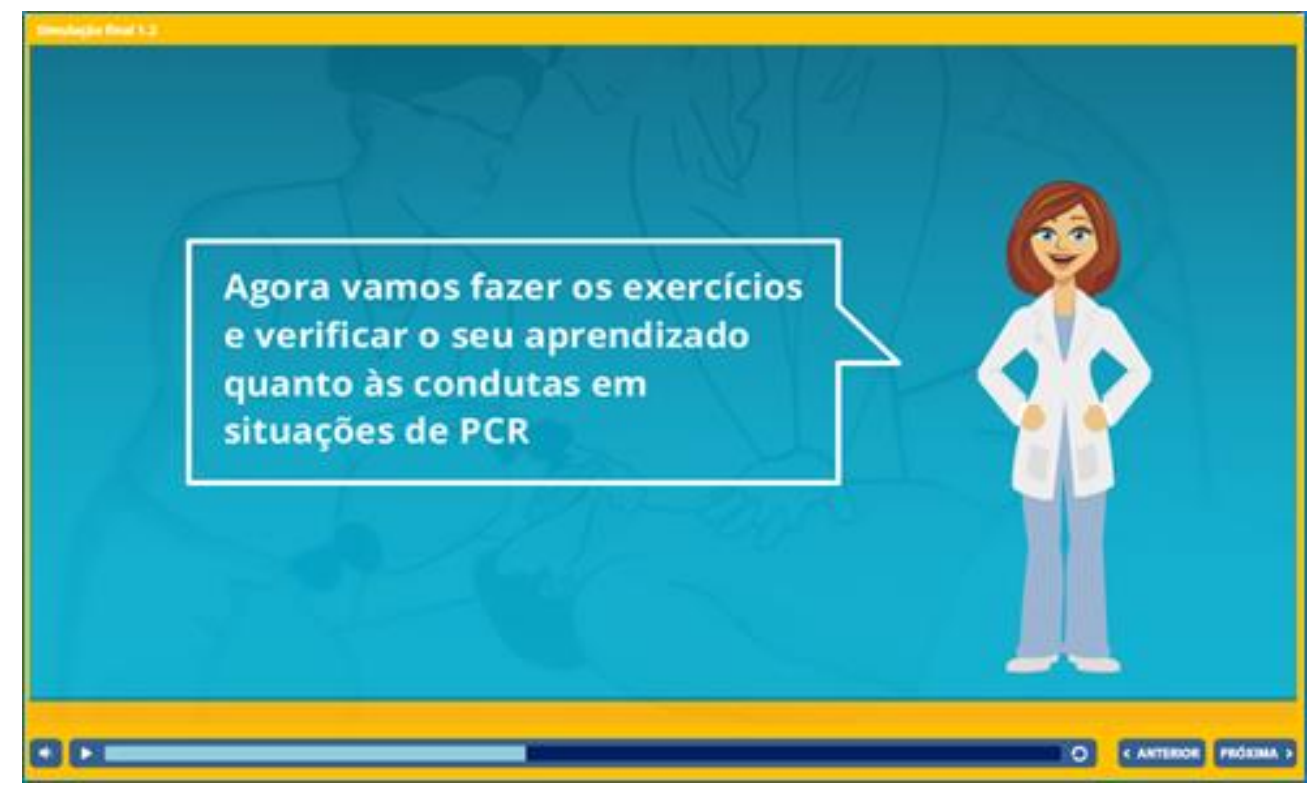

Fonte: Dados da pesquisa.

A simulação foi estruturada com questões objetivas com múltiplas alternativas, ilustradas com imagens sobre o atendimento de PCR, que buscam reforçar a resposta esperada e aproximar o participante das situações apresentadas. Após assinalar a resposta de cada questão e clicar em enviar, o participante recebe imediatamente o feedback. Se a resposta for correta, receberá cumprimentos positivos e orientações para reforço do aprendizado. Se incorreta, é convidado a rever o conteúdo e tentar responder a questão novamente (Figura 21). 
Figura 21 - Telas representativas das questões e feedback da simulação virtual.
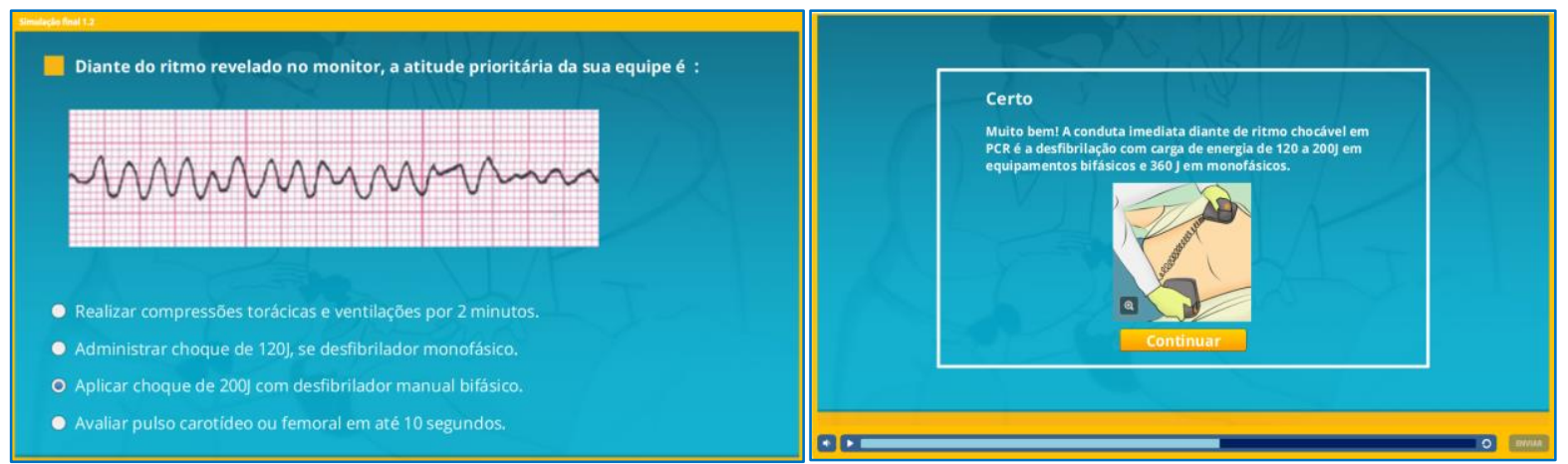

Fonte: Dados da pesquisa.

Ao término das questões, uma síntese da performance do participante é exibida e o mesmo pode revisar suas respostas ou realizar o teste novamente. Ao acertar todas as questões, o paciente David estará salvo e o certificado de conclusão do curso será enviado por e-mail. Caso não seja atingido $84 \%$ de acerto, o participante é convidado a retornar os estudos e fazer o exercício novamente. Cabe esclarecer que é possível realizar os testes da simulação quantas vezes forem necessárias, visando a apropriação do conhecimento.

\subsection{AVALIAÇÃO DA QUALIDADE DO CURSO ON-LINE NA PERSPECTIVA DE ESPECIALISTAS}

O curso on-line foi avaliado por dezesseis especialistas, sendo oito enfermeiros com atuação na área de urgência e emergência ao adulto e oito com experiência em educação online.

O perfil dos especialistas foi identificado, segundo o sexo, idade, área de formação, tempo de experiência profissional na área e maior titulação acadêmica.

Os especialistas que responderam a pesquisa eram predominantemente do sexo feminino (81,25\%), com idade média de 43 anos, enfermeiros de formação em sua totalidade, sendo que um também somava a formação de designer instrucional. O tempo de formação profissional variou entre 08 e 31 anos e o de experiência foi superior a 07 anos. 
Destaca-se, ainda que, sete $(43,75 \%)$ dos avaliadores possuíam especialização, cinco $(31,25 \%)$ haviam concluído o mestrado e quatro $(25 \%)$ o doutorado.

Estes dados podem ser vistos na Tabela 1.

Tabela 1 - Caracterização dos especialistas que avaliaram o curso on-line. São Paulo, dezembro de 2016.

\begin{tabular}{llc}
\hline Características dos Especialistas & $\mathbf{N}$ & $\mathbf{\%}$ \\
\hline Total & $\mathbf{1 6}$ & $\mathbf{1 0 0}$ \\
Sexo & 13 & 81,25 \\
$\quad$ Feminino & 03 & 18,75 \\
$\quad$ Masculino & & \\
Idade & 14 & 75,00 \\
32 - 49 anos & 04 & 25,00 \\
50 anos e mais & & \\
Tempo de Formação & 11 & 68,75 \\
8 a 20 anos & 5 & 31,25 \\
21 anos e mais & & \\
Titulação Acadêmica & 07 & 43,75 \\
Especialização & 05 & 31,25 \\
Mestrado & 04 & 25,00 \\
Doutorado & & 13,75 \\
\hline Tempo de Experiência nas Áreas Correlatas & 03 & \\
8 - 20 anos & & \\
21 anos e mais & & \\
\hline Fo & & \\
\hline
\end{tabular}

Fonte: Dados da pesquisa.

Dos 20 itens que constituem o instrumento de avaliação, sete (35\%) dos aspectos foram considerados pelos especialistas de Alta qualidade, oito (40\%) como de Boa e cinco (25\%), de qualidade Mediana (Tabela 2). 
Tabela 2 - Distribuição das médias e desvio padrão dos valores obtidos nas avaliações do curso online realizadas pelos especialistas. São Paulo, dezembro de 2016.

\begin{tabular}{|c|c|c|c|c|}
\hline Aspectos & $\mathbf{N}$ & Média & DP & Qualidade* \\
\hline & 16 & & & \\
\hline Navegação Livre & & 0,95 & 0,10 & Alta \\
\hline Clareza das Informações & & 0,94 & 0,15 & Boa \\
\hline Facilidade de Localização das Informações & & 0,92 & 0,15 & Boa \\
\hline Pertinência & & 0,98 & 0,06 & Alta \\
\hline Contextualização & & 0,97 & 0,18 & Alta \\
\hline Correção de Conteúdo & & 0,97 & 0,12 & Alta \\
\hline Múltiplas Janelas & & 0,87 & 0,19 & Mediana \\
\hline Facilidade de Aprendizagem na Interação & & 0,94 & 0,11 & Boa \\
\hline Eficiência de Utilização & & 0,94 & 0,11 & Boa \\
\hline Facilidade de Retorno & & 0,83 & 0,23 & Mediana \\
\hline Ergonomia & & 0,94 & 0,14 & Boa \\
\hline Estética & & 0,92 & 0,15 & Boa \\
\hline Uso de Marcas Especiais & & 0,88 & 0,18 & Mediana \\
\hline Utilização de Recursos Audiovisuais & & 0,92 & 0,12 & Boa \\
\hline Referências & & 0,97 & 0,08 & Alta \\
\hline Interatividade & & 0,94 & 0,14 & Boa \\
\hline Gestão de Erros & & 0,87 & 0,18 & Mediana \\
\hline Ajuda aos Usuários & & 0,89 & 0,16 & Mediana \\
\hline Qualidade da Informação & & 0,95 & 0,13 & Alta \\
\hline Portabilidade & & 0,98 & 0,07 & Alta \\
\hline
\end{tabular}

*Conforme padrão estabelecido no instrumento de avaliação.

Fonte: Dados da pesquisa.

Os 7 itens considerados de Alta qualidade pelos especialistas foram:

Navegação Livre (0,95) refere-se a autonomia do usuário no uso dos comandos para navegar no ambiente de aprendizagem na sequência desejada. Um especialista sugeriu que os 
botões Retornar; Avançar; Tentar Novamente; Continuar, que ajudam na progressão, deveriam ser de cores diferentes e serem posicionados sempre no mesmo local para evitar confusão e retardo na visualização e identificação dos mesmos. Essas modificações são pertinentes e foram realizadas.

Outros dois especialistas relataram dificuldade para sair da avaliação diagnóstica e serem direcionados para o curso e consideraram que a navegação não estava livre para retornar ao curso ou à página inicial. Esta opção somente era possível ao término da avaliação diagnóstica quando o participante enviava as respostas e, então, o resultado e o plano de curso sugeridos eram apresentados, assim como a opção de retornar para a página inicial.

Pertinência $(\mathbf{0 , 9 8 )}$ verifica se o conteúdo é apresentado de forma lógica e se os modos de interação e navegação são rapidamente compreendidos. Os avaliadores consideraram que os conteúdos são abordados de maneira lógica com compreensão rápida dos modos de interação e navegação. Entretanto, um especialista mencionou ser essencial a leitura prévia do tutorial para nortear a navegação. Houve cuidadosa preocupação no desenvolvimento e apresentação do conteúdo de maneira sistemática e objetiva com a intenção de contribuir com os participantes que possam ter maior dificuldade na compreensão do tema.

Contextualização $(\mathbf{0 , 9 7 )}$ ratifica se o conteúdo está adequado e coerente com a área e o nível de ensino propostos. Os especialistas mencionaram que o conteúdo se encontra adequado para estudante de graduação e para enfermeiro que atua em unidade de cuidados não críticos e sugeriram que, para profissionais de áreas críticas, deveria ter abordagem mais aprofundada.

Prevendo a participação de "enfermeiros", independente da área de atuação, os conteúdos foram organizados para contemplar o aprendizado de todos com possibilidade de aprofundamento por meio do material complementar e de apoio disponível na biblioteca. Nesta perspectiva e, considerando que muitos enfermeiros são imigrantes digitais, o curso foi estruturado em unidades de aprendizagem análogas e com quantidade de hiperlink razoável para facilitar a navegação pelo conteúdo e favorecer o processo de aprendizagem.

Correção de Conteúdo $(\mathbf{0 , 9 7 )}$ avalia o rigor científico dos conhecimentos transmitidos. Os experts consideraram que os conhecimentos estão aprofundados e são descritos de forma clara e baseados nas atuais diretrizes nacionais e internacionais para o atendimento 
cardiovascular de emergência. A abordagem das manobras de SAV seguiu o algoritmo da AHA/2015 que norteia o atendimento de PCR.

Referências $(\mathbf{0 , 9 7 )}$ concerne à apresentação das fontes do conteúdo e das informações do autor. As referências foram avaliadas como de alta qualidade por serem atualizadas e relevantes. Um especialista sugeriu citar referências no texto. A sugestão foi aceita e efetuada.

Qualidade da Informação (0,95) avalia se os conteúdos estão corretos, as fontes são fidedignas, o vocabulário é adequado ao público e a carga informacional (quantidade de informações) é compatível. Foi mencionado que esse critério foi elaborado com propriedade técnica. Dois especialistas sugeriram que, em alguns momentos, há excesso de informações textuais que podem ser minimizadas por meio de "hiperlinks, pop ups, caixas explicativas, saiba mais e curiosidades" para proporcionar maior clareza na apresentação do conteúdo e leveza na leitura.

Para contemplar essas sugestões, o conteúdo foi revisado quanto a quantidade de informações e novos formatos de apresentação de pontos-chaves serão adotados.

Portabilidade (0,98) avalia se funciona adequadamente em diferentes browsers. Alguns especialistas relataram que o acesso ao curso em diferentes navegadores foi fácil, outros não souberam avaliar este item. Durante a fase de implementação do curso, foram realizados testes em diversos browsers e dispositivos, com funcionamento adequado.

Um especialista mencionou dificuldade de interagir com os jogos por meio do celular. No desenvolvimento do curso on-line, procurou-se utilizar recursos simples e práticos para facilitar a navegação e a interatividade dos participantes considerando-os como nativos ou imigrantes digitais.

Os 8 itens considerados de Boa qualidade pelos especialistas foram:

Clareza das Informações $(\mathbf{0 , 9 4 )}$ diz respeito a abordagem de um conceito básico, de maneira clara e, de preferência, em uma única janela para facilitar o entendimento das informações. Os avaliadores mencionaram que o conteúdo está bem completo e os conceitos estão claros e evoluem em complexidade. Entretanto, especialistas apontaram também que algumas questões da avaliação diagnóstica e outros conceitos estão densos prejudicando o entendimento e a clareza. As indicações de necessidade de melhoria na apresentação do conteúdo são pertinentes e foram acatadas. 
Facilidade de Localização das Informações $(\mathbf{0 , 9 2 )}$ avalia se o curso on-line dispõe de mecanismos que facilitam a localização das informações pelo usuário e como ele está estruturado. Dois especialistas consideraram que o tutorial apresenta informações claras e objetivas que facilitaram a compreensão e visão sobre o desenvolvimento do curso, e um avaliador sugeriu inserir no tutorial breve definição sobre a técnica "Pomodoro" que consite em estratégia de estudo visando a otimização do tempo do participante para situá-lo.

Houve considerações positivas em relação a entrada aleatória do glossário, porém foi mencionado por um avaliador que os termos disponibilizados nas diversas páginas do curso não necessariamente apresentavam relação com a temática que estava sendo abordada naquele contexto. Outra observação é que este recurso poderia ser utilizado com fonte e cor diferentes para favorecer a visualização e prevenir sobrecarga de informações ao usuário.

Para minimizar a poluição visual, a rota de aprendizagem foi disponibilizada dentro do tutorial, no entanto avaliadores sugeriram que fosse apresentada em ícone individual na aba superior. O tutorial com as informações gerais sobre o curso e a rota de navegação foram disponibilizados nas telas Inicial e do Plano de Curso em ícone personalizado para acesso às orientações. Avaliadores sugeriram, ainda, descrever com maior ênfase o público-alvo do curso. Foi acrescentado no tutorial que o curso é destinado aos enfermeiros, independente da experiência profissional ou tempo de formação.

Facilidade de Aprendizagem na Interação (0,94) permite compreender rapidamente se a interação no software e a navegação são de fácil entendimento. Especialistas consideraram que a interação com o software é fácil e a navegação é básica e, dessa maneira, favorecem a utilização pelos usuários que tem pouca familiaridade com essas ferramentas. No entanto, surgiu comentário que, inicialmente, a interação com o ambiente pareceu complexa, mas que, rapidamente, esta dificuldade foi superada e que a leitura prévia do tutorial é fundamental para minimizar possíveis percalços.

Eficiência de Utilização (0,94) avalia se a navegação é simples e se todas as informações e comandos apresentados são relevantes para a utilização no curso. As informações e os comandos apresentados foram considerados necessários, no entanto, foi sugerido que, ao selecionar a opção do Retornar, seja direcionado para a página do Plano de Curso ao invés da página Inicial e houvesse outras opções de navegação pelo curso para evitar o retorno frequente ao menu inicial, sempre que se objetiva interagir com outro conteúdo. 
A sugestão de retorno diretamente para tela Plano de Curso com menu dos tópicos é pertinente e foi reconfigurada. A apresentação do recurso Menu em todas as telas foi evitada para minimizar poluição visual.

Dois especialistas relataram que alguns hiperlinks conduzem à biblioteca geral e não exatamente ao artigo referenciado. Como indicado, os hiperlinks foram direcionados diretamente aos arquivos desejados.

Ergonomia (0,94) avalia se há preservação da interação e da apresentação dos recursos utilizados na navegação de maneira uniforme e eficiente. Um especialista mencionou que a apresentação uniforme dos botões e ícones favoreceu o reconhecimento das áreas disponíveis, e outro avaliador relatou que o botão de Enviar não está fixo na tela e, por vezes, se sobrepõe aos textos.

No curso on-line, buscou-se manter o padrão dos ícones em quantidade e localização para favorecer o rápido reconhecimento das funções e a navegação de maneira eficiente. No caso desse botão, que eventualmente apareceu em local não padronizado, foi reconfigurado.

Estética (0,92) verifica se o objeto dispõe de padrões de interface adequados ao conteúdo. Mencionaram que os padrões visuais de cor e desenho dos elementos estão equilibrados, mas o som poderia ser melhor explorado. Dois especialistas sugeriram reduzir a carga informacional do quadro que resume as causas reversíveis da PCR e aumentar a fonte das palavras, enquanto outro avaliador indicou aumentar a fonte dos textos que compõem o curso. O tamanho da fonte dos textos e quadros foram reajustadas para facilitar a leitura nos diversos dispositivos.

Utilização de Recursos Audiovisuais (0,92) avalia se os recursos audiovisuais são adequados. Um especialista considerou que os vídeos eram excelentes. Houve sugestões de inclusão de mais vídeos e também de avatares para introduzir o curso e para conduzir o participante aos diversos contextos. O avatar foi utilizado para apresentação inicial da simulação, não sendo, portanto, utilizado em outros contextos, assim como não foi possível a inclusão de outros vídeos, em razão do tempo e recursos necessários para a produção.

Outro especialista mencionou ausência de legenda em alguns vídeos. Esta indicação foi revisada e corrigida. 
Interatividade (0,94) avalia a interação com o software e permite que o usuário participe mais ativamente do processo de aprendizagem e não fique passivamente recebendo informações. Dois especialistas relataram que os jogos digitais, os exercícios e a simulação vitual estão muito bons e que conferiram um diferencial na proposta de aprendizagem apresentada pelo curso. Para outro, o jogo da nave é difícil para quem não tem habilidade com as tecnologias.

Foi sugerida a alteração do nome Diversão por exercício interativo no link de chamada para esta atividade. Outra observação diz respeito ao uso de narrativa nos textos e que estas sejam estendidas para a contextualização dos jogos, quebra-cabeças, simulação, vídeos entre outros.

Os 5 itens considerados de qualidade Mediana pelos especialistas foram:

Múltiplas Janelas $(\mathbf{0 , 8 7})$ avalia se o curso permite abrir várias janelas simultaneamente, se necessário, para apresentar informações parcialmente sobrepostas.

Três especialistas sugeriram explorar mais este recurso, pois o mesmo favorece a interatividade e permite explorar conteúdos extras e correlacionados. Em contrapartida, outro avaliador considera que a abertura de várias janelas simultâneas pode resultar em excesso de informação na tela e causar confusão no participante. Outros dois especialistas não identificaram esse recurso e não avaliaram.

Considerando a complexidade do tema e o perfil dos participantes, a abertura de janelas simultâneas foi utilizada de maneira moderada com o intuito de possibilitar o acesso aos conteúdos e a outros complementares, mas sem excesso para não gerar transtornos e dificuldades de navegação e interatividade ao participante, em especial aqueles que possuem pouca habilidade com a tecnologia digital.

Facilidade de Retorno $(\mathbf{0 , 8 3})$ refere-se ao retorno fácil a localizações anteriores, caso ocorra condução a informações inesperadas e/ou indesejadas durante a navegação. Mencionaram que o retorno é fácil quando se deseja ir a última página visitada; em contrapartida, para acessar páginas anteriores, era necessário acessar tela por tela, o que demandou mais tempo. Outros dois especialistas comentaram que o retorno foi prejudicado nas páginas da avaliação diagnóstica e, quando se desejava acessar o Plano de Curso, o 
direcionamento era sempre para página inicial que apresentava este ícone e, então, remetia para página com o menu dos tópicos e localização dos temas.

A opção de Retorno para página inicial sempre que o participante desejava sair da tela visava facilitar o retorno e evitar transtornos de navegação e localização dos conteúdos. A disponibilização do recurso Menu em todas as telas resultaria em poluição visual.

Uso de Marcas Especiais (0,88) avalia se o curso utiliza marcas especiais como cores, molduras e outras para facilitar o reconhecimento do contexto em que se encontra. É interessante que, ao mudar de contexto durante a navegação pelo curso, o leitor receba indicações visuais a respeito do ponto em que se encontra, facilitando a sua orientação. Um especialista relatou que, em alguns momentos, a barra com a palavra GEPETE ficou localizada no meio da tela, dificultando a leitura do material - essa barreira foi identificada e corrigida.

Outro avaliador sugeriu utilizar paleta de cores para alterar a cor ao mudar de contexto para conferir interações visuais diferenciadas. A uniformidade na utilização de cores, molduras e ícones foi previsto para facilitar a identificação de pontos chaves e para evitar fadiga visual durante os estudos.

Gestão de Erros $(\mathbf{0 , 8 7})$ avalia os mecanismos que permitem prevenir ou reduzir a ocorrência de erros e, quando ocorrem, estes mecanismos favorecem a sua correção. Mencionaram que os feedbacks dos exercícios são apropriados e ajudam a fixar o conteúdo, no entanto, quando se erra a alternativa, são disponibilizadas duas opções - responder novamente ou seguir para próxima questão - e, quando o participante escolhe a segunda opção, recebe o feedback com a resposta correta e as justificativas das alternativas incorretas.

Os exercícios foram reconfigurados para conduzir o participante à próxima questão, quando este indica a alternativa incorreta e não quer responder novamente a questão como previsto no planejamento do curso.

Um especialista sugeriu apresentar feedback das respostas incorretas da avaliação diagnóstica, entretanto, em razão de seu caráter investigativo não foi disponibilizado feedback para as questões. Ao concluir o questionário, o participante recebe o resultado da avaliação diagnóstica e, quando há erro em alguma questão, é sugerido o estudo da unidade de aprendizagem referente ao tema e a realização dos exercícios que dispõem de feedback. 
Ajuda aos Usuários $(\mathbf{0 , 8 9})$ avalia se há disponibilidade de recursos para auxílio ao usuário. Avaliadores relataram que algumas páginas do curso não possuem o auxílio ao usuário de maneira visualmente rápida e que este recurso poderia ser melhor explorado para oferecer ao usuário canal de comunicação mais evidente. O curso dispõe do recurso Dúvidas como meio de comunicação prático e rápido nas páginas Inicial e do Plano de Curso que, mediante o envio da mensagem pelo participante, o tutor/professor recebe-a por meio do próprio AVA e por correio eletrônico. Para dinamizar essa comunicação, a sugestão foi aceita e realizada a inserção do ícone de acesso ao canal de Dúvidas em todas as telas do curso. 
5 DISCUSSÃO DOS RESULTADOS 



\section{DISCUSSÃO DOS RESULTADOS}

A análise dos dados será apresentada em conformidade com os objetivos da pesquisa, relacionados ao desenvolvimento e à avaliação da qualidade do curso on-line por especialistas.

O desenvolvimento do curso on-line sobre SAV em PCR foi baseado no modelo do Design Instrucional Contextualizado (DIC) para nortear o planejamento, o desenvolvimento, a aplicação e a avaliação das situações didáticas no AVA. O curso estruturado em nove unidades de aprendizagem aborda aspectos teóricos sobre as intervenções de SAV, seguindo o algoritmo de SAV para o atendimento ao paciente adulto em PCR.

A implementação de projetos educacionais sobre a temática SAV em PCR do adulto é altamente relevante e a capacitação frequente em reanimação cardiopulmonar (RCP) baseada em evidências científicas e pautada em princípios educacionais é ressaltada nas diretrizes da AHA para otimizar a assistência de alta qualidade aos pacientes, e que esta influencie significativamente no sucesso da reanimação e no aumento da chance de sobrevivência ${ }^{(19,99)}$.

Destaca-se, ainda, a importância do investimento em novas modalidades de ensino na abordagem do suporte básico e avançado de vida, como a autoaprendizagem por meio de vídeos e/ou módulos em computador, proporcionando oportunidades de capacitar os profissionais de saúde, com redução de custo e de recursos necessários ${ }^{(19)}$.

Segundo a AHA, são crescentes as evidências de que a recertificação em suporte básico e avançado de vida a cada dois anos é insuficiente para a maioria das pessoas e, apesar de não haver determinação de prazo ideal para a reciclagem, observa-se melhora nas habilidades e na confiança entre os profissionais que recebem a capacitação com mais frequência. Entre os fatores que influenciam na determinação deste intervalo estão a qualidade do curso inicial, o fato de que algumas habilidades podem ser mais propensas a deteriorarem-se do que outras e a frequência com que são utilizadas na prática clínica ${ }^{(19)}$.

A construção do curso on-line sobre SAV em PCR, mediada pela tecnologia e apoiada pelo DIC, visou oferecer estratégias pedagógicas inovadoras que mobilizem o aprendiz a construir seu próprio conhecimento, levando em consideração seus saberes prévios e, dessa 
maneira, torne a aprendizagem mais prazerosa e significativa no ensino de enfermagem em emergência.

No uso de tecnologias no ensino, a definição de objetivos educacionais intenciona direcionar o DIC, bem como o processo de avaliação da aprendizagem de maneira precisa e contextualizada $^{(100)}$.

Os objetivos educacionais devem ser claros e focados no participante, elaborados de acordo com as recomendações das teorias de aprendizagem e após a verificação das necessidades de curso e de quais competências precisam ser ensinadas e aplicadas no trabalho, para que o curso seja efetivo $^{(101)}$.

No curso on-line sobre SAV em PCR, conforme recomendado na literatura, foram traçados os objetivos educacionais relacionados à solução de problemas e à construção de significados que necessitam ser priorizados, permitindo aos aprendizes selecionar conteúdos que atendam às suas necessidades de aprendizagem ${ }^{(28)}$.

No DIC, vislumbra-se a possibilidade de criar atividades mais complexas, com percursos menos ou mais estruturados, que podem combinar fluxos diversificados conforme perfis, estilos ou resultados de aprendizagem e aprendizes livres para tomar decisões sobre o próprio processo de aprendizagem. Entre as estratégias possíveis estão: decidir entre percursos diferenciados, tipos de atividades e de interação, modos de exibição de conteúdos e formatos de avaliação $^{(102)}$.

Para tanto, o delineamento do curso on-line foi norteado nos princípios da andragogia e da TAS, aliado às novas tecnologias educacionais na busca de potencializar a autonomia e favorecer a aprendizagem significativa do aprendiz na construção do conhecimento de maneira autoinstrucional e à distância ${ }^{(50)}$. O aprendiz é livre para realizar os estudos quando, onde e como quiser, por meio de um plano de estudo, desenhado por ele e que atenda as suas necessidades.

A andragogia propõe enfatizar a aquisição de competências e a autodireção do aprendiz e não focar no conteúdo, como a teoria tradicional ${ }^{(58)}$. A adoção dos pressupostos andragógicos na construção do curso mostra-se coerente por estar direcionada a profissionais adultos da área da saúde e tem consciência do que precisam aprender. 
Os adultos geralmente preferem certo grau de autonomia para direcionar seus estudos e escolhas e a utilização da proposta andragógica no curso objetiva incentivar os aprendizes a expressarem suas necessidades, possibilitando ritmos e caminhos personalizados, discussões do seu ponto vista e a adoção de papel ativo na própria aprendizagem ${ }^{(56)}$.

$\mathrm{Na}$ andragogia, o aprendiz adulto é diferenciado e se reconhece independente, visto que já passou por diversas situações e transformações de pensamentos e atitudes, procura aproveitar experiências anteriores - quantitativa "anos de vida" e qualitativamente "diversidade de papéis e de contextos da existência"- como conhecimentos prévios e as utilizam como âncoras para a aprendizagem significativa ${ }^{(61)}$.

Nessa conjectura, na aprendizagem significativa não ocorre apenas a retenção da estrutura básica do conhecimento, mas se desenvolve a capacidade de utilizar e transferir esse saber em outra circunstância diferente daquela em que a aprendizagem aconteceu inicialmente $^{(103)}$.

Desse modo, o curso on-line sobre SAV em PCR propôs a educação centrada no profissional, fazendo com que seja o sujeito do seu processo de aprendizagem, na identificação das lacunas de conhecimento quanto a temática e no planejamento dos estudos das unidades de aprendizagem que mais lhe interesse e, ainda, possa aproveitar suas experiências prévias para ampliar os conhecimentos e tornar a aprendizagem significativa, e consequentemente, aplicála no ambiente de trabalho.

A utilização do DIC no curso on-line sobre SAV em PCR consiste em aspecto essencial para favorecer a aprendizagem significativa, principalmente no que se refere ao planejamento dos recursos tecnológicos, da interação, da cooperação e da colaboração entre aprendizes, professores e tutores, contribuindo para a efetividade do processo ensino aprendizagem ${ }^{(104)}$.

No presente estudo, o ambiente virtual de aprendizagem adotado foi o software Moodle ${ }^{\circledR}$ versão 3.1 por favorecer o uso da tecnologia na educação e disponibilizar recursos e ferramentas educacionais capazes de potencializar o desenvolvimento da aprendizagem cognitiva, dialógica e flexível aos enfermeiros, com acesso irrestrito a todas as unidades de aprendizagem e liberdade de escolha dos conteúdos a serem consultados, estudados e impressos, se desejado. 
A utilização do AVA no processo educacional permite integrar diversas tecnologias e teorias de aprendizagem, resultando no enriquecimento das ações educacionais ${ }^{(105)}$ e na ampliação das oportunidades de aprendizagem que explorem as potencialidades de cada participante para que possam acompanhar as mudanças da atual sociedade da informação ${ }^{(42)}$.

$\mathrm{Na}$ avaliação do curso on-line, os especialistas atribuíram valores de alta e boa qualidade para $15(75 \%)$ critérios relacionados aos aspectos de conteúdos (pertinência, qualidade e clareza das informações, contextualização, correção de conteúdo e referências) e à interface do ambiente (navegação livre, facilidade na interação e na localização das informações, eficiência de utilização, ergonomia, estética, interatividade, utilização de recursos audiovisuais e portabilidade).

Buscou-se desenvolver o curso on-line sobre SAV em PCR de maneira clara, concisa, lógica, pertinente, com alto rigor técnico científico, vocabulário adequado, material complementar, bem como referências atualizadas e relevantes para proporcionar maior clareza na apresentação do conteúdo e facilitar a contextualização do tema e o aprendizado.

Educadores ratificam a importância de disponibilização de glossários, referências e links e materiais para leituras complementares para ampliação do conteúdo aos interessados em aprofundar os temas desenvolvidos ${ }^{(84)}$.

O curso on-line foi configurado para funcionar em diversos browsers e dispositivos. Fator relevante em razão dos rápidos avanços tecnológicos que permeiam a sociedade, a saúde e a educação. A interação da tecnologia com o usuário resulta em maior potencialidade do uso do computador na educação ${ }^{(106)}$.

A portabilidade é a característica do produto que pode ser manipulada de maneira fácil e adequada em diferentes configurações de equipamentos além da original e que permita a adaptabilidade, capacidade de ser instalado e ou substituido ${ }^{(106)}$. E o grau de importância desse aspecto é maior quando o curso destina-se a aplicações em diferentes instituições e cenários ${ }^{(87)}$.

Os recursos audiovisuais e os dispositivos multimídia foram avaliados como de boa qualidade pelos especialistas, tendo sido desenvolvidos com a finalidade de apoiar o processo de aprendizagem e promover maior interação do usuário com o material didático por meio de interfaces amigáveis ${ }^{(38,107)}$. 
A interface do curso também foi avaliada como de boa qualidade pelos especialistas. Foi estabelecida com o propósito de manter o desenho do ambiente de aprendizagem claro, conciso e objetivo, visando facilitar a navegação e a utilização pelo participante, bem como favorecer o rápido reconhecimento das funções e de localização das informações e prevenir sobrecarga visual. O uso de interface simples e intuitiva com padrão e consistência de cor, fonte, layout, fundos, bordas em ambiente de aprendizagem torna-o mais agradável e atrativo ${ }^{(31)}$. Estes aspectos avaliados estão em concordância com a utilizabilidade que tem por finalidade determinar a conveniência e a viabilidade de utilização do produto ao longo do tempo ${ }^{(93)}$.

No curso on-line sobre SAV em PCR, estabeleceu-se padrão de localização e cores e da apresentação do material didático como ícones, janelas, imagens, animações e vídeos. Há elementos que são fixos nas páginas, como o menu, os botões, o formato das páginas e as cores utilizadas no AVA. Estas ações trazem a sensação de conforto e economia de tempo ao usuário, orientando onde estão os controles do sistema e como manipulá-los. A configuração do ambiente com o Plano de Curso individualizado, também contribui para nortear o participante nos estudos.

A disponibilização do tutorial de orientação e da rota de navegação, que fazem parte das informações iniciais ao curso, foram elaboradas para orientar a construção do ambiente de aprendizagem e definir as conexões internas entre os elementos que compõem o sistema, ou seja, estabelecer o modo como o aprendiz irá se guiar pelo AVA. Esses recursos são essenciais em cursos on-line por facilitarem a introdução do participante ao contexto e ao material didático ${ }^{(80)}$.

O curso on-line foi configurado para permitir livre navegação entre as unidades de aprendizagem, conforme o ritmo de aprendizagem para favorecer a autonomia do usuário no uso dos comandos, em coerência com o público-alvo, que são adultos, e preferem a liberdade e autonomia para realizar seus estudos. O livre acesso aos conteúdos é apontado na literatura como recurso que favorece e estimula o aprendizado e o interesse pelo curso ${ }^{(84)}$. Esse aspecto foi avaliado como de alta qualidade pelos especialistas.

A navegação livre entre todo o percurso do curso foi muito bem avaliada pelos especialistas, no entanto, foram apontadas dificuldades de navegação na avaliação diagnóstica com sugestões de padronização de cores e de estabelecimento de botões que auxiliem na progressão das páginas. 
Os aspectos tecnológicos referentes à facilidade de retorno, uso de marcas especiais, gestão de erros, múltiplas janelas, ajuda aos usuários, correspondem a apenas cinco (25\%) atributos que foram qualificados como medianos, sendo apontadas sugestões e melhorias.

Considera-se que o uso do recurso Lição do Moodle ${ }^{\circledR}$ no curso como estratégia de apresentação do conteúdo com possibilidades de navegação por múltiplas janelas, links e hiperlinks possa ter contribuir para essa avaliação.

Entretanto, a adoção do recurso Lição do Moodle ${ }^{\circledR}$ para estruturar e apresentar o conteúdo das unidades de aprendizagem intencionou favorecer a apresentação de informações organizadas em páginas interligando textos, imagens, vídeos, áudios, exercícios, jogos e links e estimular o aprendizado autônomo, privilegiando estratégias de ensino interativas e que propicie ao participante liberdade para aprender no seu ritmo e estilo de aprendizagem $^{(108)}$, bem como maior retenção do conhecimento e melhora da aprendizagem ${ }^{(80)}$.

Em se tratando de estruturação das unidades de aprendizagem, no planejamento das páginas da Lição do Moodle®, a elaboração dos storyboards facilitaram a comunicação entre as equipes de produção e a pesquisadora do projeto. Essa estratégia funciona como roteiro para organizar e detalhar os conteúdos, otimizando o tempo e os custos do desenvolvimento ${ }^{(109)}$.

Corroborando com a literatura, o curso on-line foi desenvolvido, baseado na aprendizagem de adultos e constituído por conteúdo relevante e abrangente associado a estratégias de avaliação que permitem a coleta de informações a respeito do alcance dos objetivos propostos, possibilitando a autoaprendizagem, a tomada de decisão e o redirecionamento das ações pedagógicas ${ }^{(78)}$.

Assim, destaca-se, como um dos diferenciais do curso on-line sobre SAV, o processo de avaliação da aprendizagem estabelecido, que conforme referendado na literatura, deve ocorrer de maneira contínua e processual, ao longo do curso e não somente por meio de provas ou testes ao final do processo educativo ${ }^{(110)}$.

As estratégias de avaliação da aprendizagem mediadas pela tecnologia objetivam trabalhar as competências cognitivas do aprendiz em maior complexidade, transformando-o em autodidata, capaz de construir o pensamento crítico e encontrar os próprios caminhos e direcionamento para o estudo on-line. 
A avaliação da aprendizagem constitui etapa importante na educação permanente que visa alcançar os objetivos educacionais, estimar a adequação dos procedimentos e as estratégias educacionais e possibilitar o acompanhamento do processo de ensino aprendizagem ${ }^{(33)}$.

No curso on-line, foram contempladas as dimensões diagnóstica, formativa e somativa da avaliação para fornecer o apoio e o feedback necessários à ampliação da aprendizagem do participante e situá-lo do que já realizou, além de dar a oportunidade para sedimentar aprendizagens e desenvolver habilidades metacognitivas ${ }^{(31)}$.

A aplicação do questionário no início do curso teve como propósito realizar a avaliação diagnóstica dos participantes quanto ao domínio dos temas a serem abordados e, dessa maneira, propiciá-los a oportunidade de reconhecer suas reais necessidades de aprimoramento.

Ao longo de todo o curso, é possível realizar continuamente a avaliação formativa por meio de exercícios e jogos digitais educacionais que buscam contribuir para a construção e apropriação do conhecimento de maneira dinâmica e lúdica. O teste final construído no formato de simulação virtual ocorre ao término do processo de ensino aprendizagem e corresponde à avaliação somativa, que permite resgatar o conhecimento prévio sobre o atendimento em PCR no SAV e compará-lo com o apreendido neste estudo.

A avaliação diagnóstica é proposta no início do curso para conhecer o aprendiz, buscar informações acerca de suas habilidades, competências e conhecimentos prévios ao processo de ensino aprendizagem a ser iniciado. E com base nesse resultado fornece subsídios ao professor para ajustar o conteúdo e as estratégias às necessidades do aprendiz ou direcioná-lo para o aprendizado mais efetivo e ou alternativo, conforme suas características e estilos de aprendizagem e, ao mesmo tempo situar o aprendiz para suas fragilidades e lacunas de conhecimento $^{(50,110)}$.

No curso sobre SAV em PCR, o propósito da avaliação diagnóstica transcende a investigação do conhecimento prévio do participante pelo educador e tem como finalidade auxiliar o participante a identificar suas fragilidades quanto ao tema e propiciá-lo a oportunidade de reconhecer suas reais necessidades de aprimoramento.

A avaliação deve expressar-se como mecanismo de diagnóstico ${ }^{(111)}$ da situação, tendo em vista o avanço e o crescimento e não a estagnação disciplinadora. Quando utilizada com propósito 
diagnóstico, torna-se capaz de provocar progressos para o desenvolvimento da autonomia e das competências esperadas ou planejadas do aprendiz.

Em se tratando da avaliação formativa, esta ocorre continuamente ao longo de todo o trajeto do curso e propicia que o professor acompanhe o aprendiz metodicamente durante o processo educativo, verifique suas dificuldades e limitações e disponibilize instrumentos estratégicos de superação como leituras complementares e repetição dos testes realizados quando julgados necessários, bem como identifica os avanços e reforça as conquistas realizadas $^{(80)}$.

Ressalta-se que o objetivo da avaliação formativa é auxiliar o aprendiz a articular os conhecimentos já existentes com os adquiridos e a atingir o saber, a compreensão e as habilidades cruciais para o seu desenvolvimento profissional ${ }^{(78,112)}$. A elaboração de exercícios de aprendizagem claros e objetivos e acompanhados de feedback buscam conscientizar o aprendiz em relação às suas fragilidades de conhecimentos e a necessidade de formulação de planos para enfrentá-las ${ }^{(112)}$.

A avaliação formativa, além de fornecer o feedback ao aprendiz sobre seus avanços e o que este precisa aprender, contribui com o professor, na identificação de lacunas do processo de ensino aprendizagem que requerem ajustes às diferenças individuais dos aprendizes ${ }^{(112)}$. Nesta modalidade de avaliação é possível utilizar diversos instrumentos com essa intencionalidade e desenvolver diferentes habilidades, visto que os aprendizes apresentam distintas características e estilos de aprendizagem. Essa diversidade nos modos de avaliação podem auxiliar no desenvolvimento de habilidades e inteligências ${ }^{(79)}$.

No curso on-line sobre SAV em PCR, a avaliação formativa foi configurada, seguiu as recomendações teóricas, não estabelecendo limites de tentativas de realização dos exercícios de feedback, para incentivar o aprendiz à revisão dos conteúdos e à elaboração de síntese provisória quando desejado, bem como o aperfeiçoamento contínuo do aprendizado ${ }^{(62,79)}$.

Os exercícios idealizados para cada unidade de aprendizagem apresentam estrutura semelhantes que se constituem de testes do tipo associação e de questões de múltipla escolha e oferecem ao participante feedback imediato de seu desempenho. Os jogos elaborados e disponibilizados ao final de cada unidade de aprendizagem destacam pontos chaves do conteúdo abordado. Esses recursos possibilitam avaliar o desempenho do participante no curso e constituem a avaliação formativa. 
Os jogos digitais, os exercícios interativos e a simulação virtual foram avaliados pelos especialistas como de boa qualidade e reforçado nos comentários que estes recursos conferiram importante diferencial na proposta de aprendizagem do curso.

Os jogos digitais como recurso educacional proporcionam engajamento e motivação, estimulam as investigações e as descobertas e permitem que os jogadores tenham experiências individuais e coletivas ${ }^{(113)}$.

Assim, os exercícios e jogos virtuais educacionais foram projetados ao longo do curso online com a intenção de contribuir na construção e na apropriação do conhecimento do participante de maneira dinâmica e divertida, incentivando-o a ser o protagonista do seu aprendizado.

Nesta proposta, durante o jogo digital, o participante é desafiado com questões que surgem durante a abordagem de cada intervenção no atendimento à PCR. Diante de cada questionamento, o jogador é estimulado a tomar decisão rápida e assertiva para cada situação enfrentada.

Na educação on-line, o uso dos jogos digitais podem despertar o interesse, aumentar a participação e a interatividade entre os participantes, bem como desenvolver a criatividade e a autonomia no processo de aprendizagem. Ainda, estimular o participante a interagir com os pontos principais do conteúdo de maneira dinâmica e lúdica, auxiliando na resolução de problemas e no alcance dos objetivos propostos.

Com relação a avaliação somativa, constata-se que o objetivo precípuo é fornecer feedback ao aprendiz, informando-o quanto ao nível de aprendizagem alcançado na conclusão da unidade de aprendizagem ou do curso para fins de classificação ou atribuição de conceitos/notas de acordo com os níveis de aproveitamento ${ }^{(31)}$.

No curso on-line, a avaliação somativa foi constituída pelo teste final, elaborado no formato de simulação virtual, visando permitir ao participante resgatar o saber prévio sobre o atendimento em PCR no SAV e compará-lo com o apreendido.

O exercício interativo foi elaborado a partir da simulação virtual de um caso clínico relacionado ao conteúdo abordado nas unidades de aprendizagem sobre o atendimento de suporte avançado de vida em PCR para que os participantes experienciem e pratiquem atividades simuladas da vida real, sem provocar prejuízos às pessoas. Ao mesmo tempo em que constroem a sequência de decisões a serem tomadas à cada situação proposta, com feedback imediato. 
A adoção de exercícios baseada em caso clínico enriquece o processo de ensino aprendizagem ao viabilizar a situação mais próxima do real e oportunizar ao aprendiz utilizar conhecimentos prévios para tomada de decisão e resolutividade do problema, transformando a aprendizagem em experiência significativa ${ }^{(55)}$.

Essa estratégia de avaliação foi selecionada por entender que a simulação virtual representa poderosa ferramenta para uso educacional e visa aproximar o participante da situação real de PCR no adulto. Neste ambiente virtual e simulado, é possível proporcionar o desenvolvimento de habilidades, de resolução de problemas, de formulação de hipóteses e de engajamento na descoberta da aprendizagem em $\operatorname{RCP}^{(114,115)}$.

A simulação virtual foi elaborada a partir da apresentação sequencial, de situações referentes ao estado clínico do paciente, exigindo a tomada de decisão do participante com escolha imediata da alternativa adequada. Esse ambiente objetivou proporcionar atender as necessidades de aprendizagem do participante de maneira autônoma e construtiva, com esclarecimento de dúvidas quanto aos conteúdos, e ainda promover o realismo, desafiar, estimular e contribuir, efetivamente, na construção de habilidades e competências requeridas para o exercício profissional do enfermeiro nas situações de emergência.

A simulação virtual em RCP configurada em AVA é entendida como a representação da estrutura ou da dinâmica do objeto real ou da proposta com o qual o participante interage ativamente no processo de ensino aprendizagem, aplica o conhecimento aprendido para responder por meio de decisões e ações a determinados problemas e recebe feedback imediato, ou seja, o participante raciocina e decide mediante informações, sem o estresse do cenário realístico ${ }^{(115)}$.

Dessa maneira, a simulação virtual representa importante oportunidade para o participante assumir papel ativo no desenvolvimento de competências concretas em ambiente virtual e imediatamente verificar as consequências de suas ações, além de oportunizar contextos de aprendizagem e cuidado em RCP, que decorrem na convergência do educar-cuidar em enfermagem $^{(115)}$.

No cenário da prática em enfermagem, em que o enfermeiro é colocado frente a situações de emergência a qualquer momento e este deve agir rápido e com precisão, reafirmase a importância do investimento contínuo na formação e na capacitação para que esse profissional desenvolva o perfil esperado. 
As Diretrizes Curriculares ${ }^{(116)}$ descrevem o perfil do futuro enfermeiro pautado na formação generalista, humanista, crítica, reflexiva, criativa e ética. No processo formativo do enfermeiro, as competências, as habilidades e os conteúdos curriculares a serem assimilados e adquiridos precisam conferir-lhe terminalidade e capacidade acadêmica e ou profissional, considerando as demandas e necessidades prevalentes e prioritárias da população, conforme o quadro epidemiológico do país e ou da região.

Desse modo, recursos mediados por tecnologia, como a simulação virtual, podem ser empregados para a formação e capacitação de profissionais da área de enfermagem em emergência visando estimular e aprofundar o aprendizado e o preparo para a tomada de decisão rápida e eficaz, sem riscos para o paciente e equipe. A simulação ${ }^{(117)}$ constitui nova possibilidade de ensino que engloba não somente as habilidades técnicas, cognitivas e comportamentais, mas também o gerenciamento de crises, a liderança, o trabalho em equipe, o raciocínio clínico em situações críticas ou outras que possam resultar em danos ao paciente real.

O uso da simulação virtual permite agregar novas abordagens para o ensino em enfermagem, valorizando a aprendizagem centrada no aprendiz, em que o mesmo atua como participante ativo do processo de construção do seu próprio conhecimento e, consequentemente, resulta em retenção do saber ${ }^{(118)}$.

Entende-se que essa estratégia, além de possibilitar o aprimoramento do conhecimento e habilidades é capaz de estimular o profissional à reflexão sobre o seu desempenho prático, assim como, as ações comunicacionais e atitudinais em relação ao atendimento à PCR. Esses pressupostos vão ao encontro das discussões atuais, acerca da ética e da segurança no cuidado em saúde ${ }^{(115)}$.

Nessa perspectiva, utilizou-se a simulação virtual como estratégia de avaliação formativa, com o intuito de proporcionar aos aprendizes a autoavaliação sobre seus conhecimentos e desenvolver competências para atuação em RCP e na prática clínica durante o atendimento em PCR, levando-o a reflexão quanto a importância de capacitação e atualização contínua. O feedback com mensagens de erro e acerto em relação à resolução dos exercícios interativos e da simulação pelos participantes ocorre imediatamente ao término de cada atividade, bem como a pontuação final alcançada na simulação virtual.

Em ambientes virtuais de aprendizagem, o feedback de exercícios é fundamental para verificação do apreendido e retomada ao conteúdo quando necessário. O ambiente deve ser 
configurado para analisar as respostas dadas pelo aprendiz, compará-las com as desejadas e discriminá-las quando a resposta estiver incorreta. Nesse caso, deve ser oferecida, ao aprendiz, oportunidade para refazer a questão ${ }^{(93)}$.

Depreende-se que a avaliação da aprendizagem na educação on-line de enfermeiros requer aspectos pertinentes ao ensino de adultos e critérios transparentes. O desenvolvimento de estratégias de avaliação deve ocorrer de maneira integrada, processual e multidimensional, alinhada aos objetivos educacionais das unidades de aprendizagem ou do curso, às concepções pedagógicas centradas no aprendiz, às condições estruturais em relação aos recursos disponíveis e à aceitação dos novos cenários que integram saúde, educação e tecnologia, o que significa permitir a autorreflexão e a autoavaliação específica para cada curso ${ }^{(31,38,62)}$.

Exige, ainda, a construção de posturas mais flexíveis, não lineares e que possam refletir em algum nível a aprendizagem real do aprendiz. Mais do que produzir esse modelo, com maior ou menor fidedignidade, deve-se priorizar que a avaliação possa servir como instrumento de constante transformação e aprimoramento dos métodos educacionais e dos pressupostos que orientam o ensino a distância ${ }^{(119)}$.

O curso on-line sobre SAV por meio do processo de avaliações da aprendizagem buscou adaptar as estratégias educacionais aos vários estilos e ritmos de aprendizagem do adulto, utilizando recursos tecnológicos, em diversos formatos e linguagens, como textos, hipertextos, imagens, ilustrações, vídeos, sites, jogos, simulação, glossário, hiperlinks, que intencionam mediar e qualificar o processo de ensino aprendizagem. Adotou, também recursos computacionais gráficos em 3D. Esses recursos favorecem a apreensão do conhecimento por meio de habilidades espaciais e visuais dos processos fisiológicos e procedimentais ${ }^{(51)}$.

A utilização desses recursos audiovisuais como vídeos, avatares e animações foram ressaltadas pelos especialistas como aspectos muito positivos e que o uso destas tecnologias poderia ser ampliada para diversos contextos do curso, a fim de conferir maior dinamicidade e interatividade na introdução e explicação de conceitos, potencializando a construção e retenção de conhecimento.

Com relação à avaliação do curso on-line sobre SAV em PCR, considera-se que esta foi uma etapa de extrema importância do projeto, visando justificar sua adoção como recurso educacional e garantir a segurança no seu uso. Diversas abordagens de avaliação estão disponíveis na literatura para apoiar essa atividade, mas a complexidade de seus critérios e a 
subjetividade de seus resultados, muitas vezes, podem confundir o avaliador e interferir na decisão sobre adoção ou não de um software educacional ${ }^{(92)}$.

A avaliação tem como objetivo final melhorar a qualidade do produto em uso. Qualidade é o grau em que o produto em uso pode alcançar objetivos para satisfazer com eficácia as necessidades específicas dos usuários ${ }^{(120)}$.

Evidencia-se que o resultado da avaliação do curso on-line fortalece a reflexão sobre as potencialidades dos aspectos educacionais e da interface do ambiente de aprendizagem para a promoção do processo de ensino aprendizagem significativo na enfermagem em emergência.

Infere-se, pelos resultados da avaliação, que o desenvolvimento de propostas educacionais possam transcender o ensino presencial, evoluindo para o virtual, propiciando impacto positivo no aprendizado e no cuidado, ao considerar adoção de metodologias baseadas em pressupostos teóricos utilizando o DIC, abordagens de experiências práticas e valorizar a orientação didática e os estilos de linguagem e de aprendizagem, assim como a clareza e a contextualização das informações.

Em estudo sobre a avaliação da qualidade de curso on-line que utiliza critérios análogos, verifica-se semelhança na qualidade dos aspectos relacionados à pertinência, correção de conteúdo, qualidade das informações, referências, estética, utilização de recursos audiovisuais, facilidade de localização das informações, múltiplas janelas e facilidade de retorno ${ }^{(38)}$.

O universo de avaliação da qualidade de objetos de aprendizagem é amplo e apresenta uma diversidade de aspectos à serem avaliados, sendo fundamental organizar e clarificar os critérios e atributos avaliativos para que possa haver credibilidade na avaliação e reduzir o nível de subjetividade ${ }^{(106)}$.

No planejamento e no desenvolvimento de curso on-line é imprescindível, discutir a qualidade do mesmo para verificar quais aspectos necessitam ser aprimorados e consequentemente, re-planejar e reconfigurar o $\mathrm{AVA}^{(68)}$.

Nesse contexto, a avaliação da qualidade de cursos on-line consiste em ação essencial para qualquer empreendimento gerador de produtos que serão utilizados para fins educacionais $^{(87)}$. 
Evidencia-se, a necessidade de que a qualidade seja controlada e avaliada e, para tanto, são necessários métodos confiáveis e validados. Estes métodos, atualmente, compõem a área de controle da qualidade definida como organização ou sistemática de todos os procedimentos necessários à confirmação de que o módulo ou produto está de acordo com as necessidades estabelecidas em sua fase de desenvolvimento ${ }^{(93)}$.

A avaliação de ambientes educacionais depende de um grupo de técnicas de análise e métricas que oferecem informações sobre as características/aspectos de qualidade do produto. É por meio desses aspectos que o produto é analisado, avaliado e verificado se atende às necessidades do usuário, sendo, então, determinada sua qualidade ${ }^{(87,88)}$.

Assim, em consonância com o referencial teórico, o processo de avaliação do curso sobre SAV em PCR foi essencial para assegurar a qualidade, antes de ser disponibilizado em sua versão final para uso educacional, sendo possível identificar deficiências e limitações do curso, verificar os aspectos técnicos e pedagógicos que requerem alterações e melhorias, bem como demonstrar que sua utilização foi adequada aos objetivos de sua concepção ${ }^{(38,87)}$.

Ressalta-se que ao considerar a importância multidimensional da avaliação de qualidade de curso on-line, conforme descrito na literatura, a inclusão de avaliadores especialistas de diferentes áreas do conhecimento como a de urgência e emergência e de educação on-line, ampliou e enriqueceu as dimensões do processo avaliativo ${ }^{(106)}$.

Diante do exposto, a avaliação não pode ser considerada meramente como o atendimento às formalidades do curso, mas sobretudo esclarecer pontos fortes e fracos do processo, levando os atores a se conscientizarem da necessidade de modificações. Nesse sentido, não é suficiente constatar as fragilidades de propostas em desenvolvimento; impõe-se um (re) pensar sobre como viabilizar os ajustes dos aspectos da avaliação considerados críticos ${ }^{(63)}$. Destaca-se, ainda, a importância da clareza dos aspectos explícitos e implícitos do processo avaliativo para compreender as relações entre si e com o todo e assim elaborar as estratégias de mudança ${ }^{(68)}$. 



\section{CONCLUSÃO}

Este estudo possibilitou desenvolver e avaliar a qualidade do curso on-line sobre SAV em PCR de adultos para enfermeiros, alcançando os objetivos propostos.

O curso on-line foi desenvolvido a partir do modelo de DIC que apresenta as fases de: análise, desenho, desenvolvimento, implementação e avaliação, bem como fundamentado nos princípios da andragogia e dos pressupostos da Teoria da Aprendizagem Significativa.

Nesse modelo de design instrucional o conjunto de fases se entrelaçam e complementam intencionando privilegiar a contextualização dos cenários da prática dos enfermeiros.

A proposta educacional foi estruturada no AVA Moodle ${ }^{\circledR}$ do GEPETE, por meio do recurso Lição do Moodle ${ }^{\circledR}$, em nove unidades de aprendizagem que abordam aspectos teóricos sobre as intervenções elencadas no algoritmo de SAV em PCR das diretrizes da AHA/2015.

A adoção desse recurso possibilitou organizar o conteúdo do curso em unidades de aprendigagem de maneira flexível, viabilizar constantes conexões entre os textos, imagens, vídeos, áudios, exercícios, jogos e links, bem como proporcionar a utilização de diversas estratégias de ensino interativas que podem contribuir com o aprendizado autônomo, respeitando o ritmo e estilo de aprendizagem de cada participante.

Na construção do curso on-line sobre SAV em PCR, a integração de tecnologias e recursos educacionais inovadores favoreceu a adoção do processo de avaliação nas dimensões diagnóstica, formativa e somativa seguidas de feedback, necessário para o direcionamento do participante no processo de aprendizagem.

Na elaboração das estratégias de avaliação, utilizou-se questionário com perguntas de múltiplas respostas, exercícios interativos, jogos digitais e simulação virtual valorizando a autonomia e os conhecimentos prévios do participante e oportunizando a interatividade e a criatividade na resolução de problemas e na construção e a apropriação do conhecimento de maneira dinâmica e lúdica para o alcance dos objetivos.

Esses recursos foram avaliados por especialistas das áreas de urgência e emergência e educação on-line que consideraram sete $(35 \%)$ critérios relacionados a navegação, pertinência, 
contextualização, correção de conteúdo, referências, qualidade da informação e portabilidade de Alta qualidade.

Com relação a clareza das informações, facilidade de localização das informações, eficiência de utilização, facilidade de aprendizagem na interação, ergonomia, estética, utilização de recursos audiovisuais e interatividade, os especialistas avaliaram esses oito (40\%) critérios como de Boa qualidade.

Os aspectos tecnológicos referentes aos cinco (25\%) atributos relacionados à facilidade de retorno, uso de marcas especiais, gestão de erros, múltiplas janelas, ajuda aos usuários, foram qualificados como Medianos, sendo apontadas sugestões e melhorias.

Frente aos resultados, pode-se observar que ações educacionais estruturadas em ambientes virtuais necessitam ser cuidadosamente planejadas e sistematicamente acompanhadas por equipe multiprofissional experiente para o alcance dos objetivos educacionais. Requer, ainda, a utilização de modelo adequado de design instrucional, bem como de referenciais teórico metodológicos e pedagógicos que norteiem a seleção dos conteúdos, dos materiais didáticos e das estratégias de ensino e de avaliação da aprendizagem.

Nessa perspectiva, depreende-se que os estudos de produção tecnológica e a constituição de linhas de pesquisas na área do ensino on-line em saúde e em enfermagem revertem-se de grande importância diante dos desafios da capacitação e atualização dos enfermeiros para o atendimento de PCR do adulto no SAV.

Assim, a educação permanente de pessoas na área da saúde torna-se imperativo, abordando temas que congreguem as questões epidemiológicas e os avanços terapêuticos e visando à capacitação de profissionais autônomos, ativos e reflexivos, capazes de articular a prática profissional e o mundo tecnológico atual da saúde e da enfermagem.

Conclui-se que o curso on-line sobre SAV em PCR pode ser considerado ferramenta inovadora para adquirir e retomar conhecimentos e experiências, tanto pela flexibilidade e mobilidade quanto pela oferta de abordagens pedagógicas mais dinâmicas que visam estimular os participantes a assumirem responsabilidades e definirem suas próprias metas e caminhos na busca do conhecimento. 


\subsection{CONSIDERAÇÕES}

Depreende-se que o desenvolvimento do curso on-line norteado pelo modelo de design instrucional contextualizado e nos pressupostos da andragogia e da Teoria da Aprendizagem Significativa representa importante contribuição para a capacitação e atualização de enfermeiros com auxílio da internet quanto ao atendimento de SAV em PCR, tendo em vista a viabilidade da utilização de recursos tecnológicos na educação em emergência.

Desse modo, os enfermeiros podem ser capacitados a partir do curso on-line com a finalidade de reconhecer precocemente a PCR, sistematizar e qualificar os cuidados específicos na reanimação cardiopulmonar e pós-PCR, a fim de que estes contribuam para o sucesso da reanimação e maior sobrevida de pacientes.

A avaliação curso on-line foi fundamental para assegurar a sua qualidade educacional, demonstrar a adequação dos pressupostos pedagógicos e do design instrucional alinhado aos objetivos, conteúdos, recursos tecnológicos e avaliação da aprendizagem, bem como identificar os aspectos que requerem melhoria e aperfeiçoamento. As sugestões apresentadas pelos especialistas serão implementadas na continuidade dessa pesquisa, previamente à disponibilização do curso on-line aos enfermeiros.

O caráter inovador da pesquisa pode ser caracterizado pela construção do curso on-line sobre SAV em PCR, que representa temática de alta relevância, estruturado com avaliações diagnóstica, formativa e somativa, utilizando-se de objetos de aprendizagem como exercícios interativos, jogos digitais e simulação virtual que possibilitam a realização de atividades individuais, flexíveis, dinâmicas, lúdicas e interativas para atualização e capacitação teórica de enfermeiros no âmbito da emergência.

Destaca-se, ainda, a importância do processo ensino aprendizagem estar em consonância às evoluções tecnológicas e estratégias que busquem mudanças significativas na educação e que representem novas oportunidades para o alcance dos objetivos educacionais e para adoção da qualidade do ensino aprendizagem.

Nessa perspectiva, julga-se que os recursos tecnológicos utilizados para configuração de ambiente virtual de aprendizagem poderão contribuir no modo de ensinar e de aprender, 
mobilizando os enfermeiros para explorar, experimentar, interagir e vivenciar situações encontradas na vida real, bem como para praticar o exercício da autonomia da aprendizagem. O desejo de aprender dos profissionais e o potencial significativo do material didático apresentado são condições fundamentais, que se complementam para que a aprendizagem ocorra.

A associação de diversos recursos multimídias e de objetos de aprendizagem como jogos virtuais, exercícios interativos e simulação virtuais podem abrir novas perspectivas para a aquisição do conhecimento sobre SAV em PCR do adulto, bem como ampliar e inovar o processo de ensino aprendizagem em educação permanente para enfermeiros. Esses recursos podem minimizar as dificuldades encontradas no processo de ensino aprendizagem na medida em que proporcionam a interatividade conforme características individuais dos aprendizes e ampliam as possibilidades de exploração perceptiva e do potencial visual e auditivo dos participantes.

O curso on-line também poderá propiciar à inclusão digital dos enfermeiros, visto que nem todos possuem domínio da utilização da tecnologia aplicada ao ensino. E, ainda, oferecer de modo confiável e seguro, orientações sobre a temática de SAV, com flexibilidade de horário e local para estudo, considerando a especificidade do trabalhador de enfermagem, que geralmente possui múltiplos vínculos empregatícios e limitação para se ausentar do trabalho para capacitação e atualização.

As inovações tecnológicas atuais permitem transformar perspectivas tradicionais de educação permanente em prol de modos mais dinâmicos, interativos e significativos de pensar e construir o saber, propiciando a imersão dos profissionais em ambientes interativos seguros para desenvolver o processo de enfermagem com segurança para o paciente, para além da sala de aula.

A estrutura do curso on-line sobre SAV em PCR ainda viabiliza compor apresentações, via sistemas de computador geralmente na internet, em diferentes cenários de atualização e de capacitação de enfermeiros, seja presencial ou a distância. O acesso ao curso on-line no ambiente de trabalho por meio de computadores ou dispositivos móveis (tecnologia acessível na atualidade) oportuniza aos enfermeiros realizar os estudos no horário de trabalho, bem como explorar conceitos, fazer associações teóricas e práticas e resolver problemas. 
Como proposta futura intenciona-se continuar a pesquisa para validar o conteúdo das questões utilizadas no processo de avaliação diagnóstica, formativa e somativa, quanto a semântica, a complexidade, o grau de dificuldade e a coerência com os objetivos educacionais e, então, aplicar o curso on-line sobre SAV em PCR aos enfermeiros e, consequentemente, ampliar a avaliação da qualidade do curso on-line na perspectiva dos aprendizes.

Considera-se que este estudo seja propulsor para novos investimentos tanto na capacitação do enfermeiro, quanto em grupos de estudo de produção tecnológica, para que outros profissionais possam desenvolver ferramentas que auxiliem o processo ensino aprendizagem, além de proporcionar diversas oportunidades para aplicação dessas mesmas tecnologias em outros processos educacionais.

Acredita-se ainda, que outra contribuição da pesquisa ao avaliar a qualidade do curso on-line sobre SAV em PCR é buscar aspectos relevantes que ajudem a transformar o processo de ensino aprendizagem tradicional em oportunidade de capacitação mais ativa e interativa para o enfermeiro conferindo-lhe novas maneiras de aprender e aplicar os conhecimentos teóricos na prática, contribuindo, assim, para a melhoria da assistência em PCR.

Os resultados da pesquisa frente aos objetivos propostos permitiram descrever as etapas do planejamento, desenvolvimento e avaliação do curso on-line sobre SAV em PCR e abrem perspectivas para acreditar que, na educação permanente em enfermagem, a tecnologia disponível pode descortinar novos modos de aprender significativamente, além de oferecer subsídios para o desenvolvimento de outros recursos informatizados voltados à capacitação e atualização em enfermagem em emergência. 

REFERÊNCIAS 



\section{REFERÊNCIAS}

1. Menezes RR, Rocha AKL. Dificuldades enfrentadas pela equipe de enfermagem no atendimento à parada cardiorrespiratória. InterScientia. 2013;1(3):2-15.

2. Alves CA, Barbosa NCS, Faria HTG. Parada cardiorrespiratória e enfermagem: o conhecimento acerca do suporte básico de vida. Cogitare Enferm. 2013;18(2):296-301.

3. Passali C, Pantazopoulos I, Dontas I, Patsaki A, Barouxis D, Troupis G, et al. Evaluation of nurses' and doctors' knowledge of basic \& advanced life support resuscitation guidelines. Nurse Educ in Pract [Internet]. 2011[cited 2017 Abr 02];11(6):365-9. Available from: http://dx.doi.org/10.1016/j.nepr.2011.03.010 11 (2011) 365e369

4. Moretti AM. Eficácia do treinamento em suporte avançado de vida nos resultados das manobras de ressuscitação cardiopulmonar. [Tese]. São Paulo (SP): Faculdade de Medicina, Universidade de São Paulo; 2002.

5. Brasil. Ministério da Saúde. Política Nacional de Educação Permanente em Saúde. Secretaria de Gestão do Trabalho e da Educação na Saúde. Portaria No 1.996, de 20 de agosto de 2007. Departamento de Gestão da Educação em Saúde. Brasília: 2009. 64p.

6. World Health Organization (WHO). Cardiovascular diseases (CVDs) [Internet] [s.d.]. [cited 2016 Jan 29]. Available from: http://www.who.int/mediacentre/factsheets/fs317/en/.

7. Brasil. Ministério da Saúde. Informações de saúde (TABNET). [Internet]. 2017. [citado 20 jan. 2017]. Disponível em: http://tabnet.datasus.gov.br/cgi/tabcgi.exe?sim/cnv/obt10uf.def.

8. Aehlert B. O ABCD do atendimento cardiovascular de emergência. In: Fontoura TBT, organizador. ACLS Suporte Avançado de Vida em cardiologia: emergências em cardiologia. Um guia de estudo. 4a ed. Rio de Janeiro: Elsevier; 2013. p. 9-28.

9. Brasil. Ministério da Saúde. Portaria No 1.600, de 7 de Julho de 2011. Reformula a Política Nacional de Atenção às Urgências e institui a Rede de Atenção às Urgências no Sistema Único de Saúde (SUS) [Internet]. 2011 [citado 2016 dez. 16]. Disponível em: http://bvsms.saude.gov.br/bvs/saudelegis/gm/2011/prt1600_07_07_2011.html.

10. Brasil. Ministério da Saúde. Política Nacional de Atenção às Urgências. Ministério da Saúde. $3^{\text {a }}$ ed. amp. Brasília; 2006. p 256.

11. Brasil. Ministério da Saúde. Regulação Médica das Urgências. Ministério da Saúde, Secretaria de Atenção à Saúde, Departamento de Atenção Especializada [Internet]. 2006 [citado 2015 jul. 16]. Disponível em: http://187.17.2.102/fhs/media/files/samu/manual_de_regulacao_medica_das_urgencias. pdf 
12. Brasil. Ministério da Saúde. Portaria No 2.048/GM de 05 de novembro de 2002. Aprova o regulamento técnico dos sistemas estaduais de urgência e emergência Diário Oficial da União. Brasília [Internet]. 2002. [citado 2015 jul. 16]. 1-138. Disponível em: <http://portal.saude.gov.br/portal/saude/ visualizar_texto.cfm?idtxt=23606>.

13. Sardo, PMG. Aprendizagem baseada em problemas em reanimação cardiopulmonar no ambiente virtual de aprendizagem Moodle ${ }^{\circledR}$. [Dissertação]. Florianópolis: Programa de Pós-Graduação em Enfermagem, Universidade Federal de Santa Catarina; 2007.

14. Goldberger ZD, Chan PS, Berg, RA, Kronick SL, Cooke CR, Lu Mi, at al. Duration of resuscitation efforts and subsequent survival after in-hospital cardiac arrest. Lancet. 2012;380(9852):1473-81.

15. Meaney PA, Nadkarni VM, Kern KB, Indik JH, Halperin HR, Berg RA.Rhythms and outcomes of adult in-hospital cardiac arrest. Crit Care Med [Internet]. 2010 [cited 2017 Fev 23]38(1):101-8. Available from: http://www.ncbi.nlm.nih.gov/pubmed/19770741

16. Girotra S, Nallamothu BK, Spertus JA, Li Y, Krumholz HM, Chan PS. Trends in Survival After In-Hospital Cardiac Arrest. N Engl J Med. 2012;367(20):1912-20 Doi:10.1056/NEJMoa1109148.

17. Gonzalez MM, Timerman S, Gianotto-Oliveira R, Polastri TF, Canesin MF, Schimidt A et al. I Diretriz de Ressuscitação Cardiopulmonar e Cuidados Cardiovasculares de Emergência da Sociedade Brasileira de Cardiologia. Rev Arq Bras Cardiol [Internet]. 2013 [citado 2017 fev. 25]. Disponível em http://www.scielo.br/pdf/abc/v101n2s3/v101n2s3.pdf

18. Silva FV, Almeida FS, Silva JR, Silva RO, Santiago PSN. Importância do treinamento em reanimação cardiopulmonar para profissionais de saúde. EFDeportes.com - Buenos Aires [Internet]. 2011 [citado 2017 jan. 23];16/156:1-6. Disponível em: http://www.efdeportes.com

19. American Heart Association. Destaques da American Heart Association 2015. Atualização das diretrizes de RCP e ACE. Versão em português. AHA [Internet]. 2015 [citado 2016 dez. 15]. Disponível em: https://eccguidelines.heart.org/wpcontent/uploads/2015/10/2015-AHA-Guidelines-Highlights-Portuguese.pdf

20. Kleinman ME, Brennan EE, Goldberger ZD, Swor RA, Terry M, Bobrow BJ, et al. Part 5: Adult basic life support and cardiopulmonary resuscitation quality: American Heart Association guidelines update for cardiopulmonary resuscitation and emergency cardiovascular care. Circulation [Internet]. 2015 [cited 2016 Dez 20];132(18):S414-35. Available from: https://eccguidelines.heart.org/index.php/circulation/cpr-ecc-guidelines2/part-5-adult-basic-life-support-and-cardiopulmonary-resuscitation-quality/ DOI: 10.1161/CIR.0000000000000259

21. Neumar RW, Otto CW, Link MS, Kronick SL, Shuster M, Callaway CW et al. Adult Advanced Cardiovascular Life Support. 2010 American Heart Association guidelines for cardiopulmonary resuscitation and emergency cardiovascular care. Circulation [Internet]. 2010 [cited 29 Nov 2016]; 122: S729-S767. Available from: http://circ.ahajournals.org/content/122/18_suppl_3/S729.full 
22. Freitas LV, Teles LMR, Lima TM, Vieira NFC, Barbosa RCM, Pinheiro AKB, et al. Exame físico no pré-natal: construção e validação de hipermídia educativa para a enfermagem. Acta Paul Enferm. 2012; 25 (4). 581-8.

23. Silva GM, Seiffert OML B. Educação continuada em enfermagem: uma proposta metodológica. Rev Bras Enferm. 2009; 62 (3): 362-6.

24. Borges-Andrade JE. Desenvolvimento de medidas em avaliação de treinamento. Estud Psicol. 2002;7(n. esp):31-4.

25. Menezes PPM. Avaliação de um curso de desenvolvimento regional sustentável no nível de resultados: a contribuição dos modelos lógicos e do método quase-experimental. [Tese]. Brasília: Instituto de Psicologia, Universidade de Brasília 2007.

26. Oliveira CD; Silveira RA. Avaliação do uso das ferramentas tecnológicas em ambientes virtuais de ensino e aprendizagem em educação a distância: um estudo de caso do ETEC/CEFET-MG. In: ESUD 2014_ XI Congresso Brasileiro de Ensino Superior a Distância; 2014 ago. 5-8; Florianópolis. Florianópolis: UNIREDE; 2014. p. 95-108.

27. Tronchin DMR, Peres HHC, Lima AFC, Alavarce DC, Prata AP, Aroldi JBC, et al. Desenvolvimento do curso de gerenciamento em enfermagem on-line: experiência exitosa entre Brasil e Portugal. Rev Esc Enferm USP. 2015;49(n. esp):162-7.

28. Filatro A. Design instrucional contextualizado. São Paulo: Senac; 2007.

29. Moran J. Contribuições para uma pedagogia da educação online. In: Silva, M. Educação online: teorias, práticas, legislação, formação corporativa. São Paulo: Loyola [Internet]. 2003 [citado 2017 jan. 14]. p. 39-50 Disponível em: http://www.eca.usp.br/prof/moran/site/textos/educacao_online/contrib.pdf

30. Lévy P. Cibercultura. Costa TCI, organizador. São Paulo: Editora 34; 1999. 264 p.

31. Filatro A. Design instrucional na prática. São Paulo: Peterson Education do Brasil; 2008.

32. Brasil. Ministério da Educação. Ambientes Virtuais de Aprendizagem. Cristiano Maciel, organizador. EdUFMT: Cuibá; 2012: 53 - 4. [Internet]. 2012 [citado 2011 mar. 16];259. Disponível em: http://disciplinas.stoa.usp.br/pluginfile.php/133410/mod_resource/content/1/Seminário Ambientes Virtuais de Aprendizagem.pdf

33. Alavarce DC. Desenvolvimento e avaliação da reação, aprendizagem e impacto de treinamento online para profissionais da saúde. [Tese]. São Paulo: Escola de Enfermagem, Universidade de São Paulo; 2014.

34. Rodrigues RCV, Peres HHC. An educational software development proposal for nursing in neonatal cardiopulmonary resuscitation. Rev Esc Enferm USP [Internet]. 2013 [citado 2016 nov. 16];47(1):235-41. Disponível em: http://dx.doi.org/10.1590/S008062342013000100030

35. Santana CMH, Pinto AC, Araújo CJSA. A ubiquidade das TDIC no cenário contemporâneo e as demandas de novos letramentos e competências na EaD. 2015; Em Rede: Rev Educ a Distancia. 2015; 2(1).100-15. 
36. Pulino Filho AR. Ambiente de Aprendizagem Moodle UnB: Manual do Professor. Brasília: Universidade de Brasília; 2005.

37. Prado C, Vaz DR, Almeida DM. Teoria da aprendizagem significativa: elaboração e avaliação de aula virtual na plataforma Moodle. Rev Bras Enferm [Internet]. 2011 [citado 2015 dez. 04]; 64(6):1114-21. Disponível em http://www.scielo.br/scielo.php?script=sci_arttext\&pid=S0034-71672011000600019

38. Tobase L. Desenvolvimento e avaliação do curso online sobre Suporte Básico de Vida nas manobras de reanimação cardiopulmonar do adulto. [Tese]. São Paulo: Escola de Enfermagem, Universidade de São Paulo; 2016.

39. Wiley D. The instructional use of learning objects. On-line version [Internet]. 2000 [cited 2015 Jun 10]. Available from: <http://reusability.org/read/>

40. Brasil. Ministério da Educação. Secretaria de Educação a Distância. Objetos de aprendizagem: uma proposta de recurso pedagógico. Prata CL, Nascimento ACAA, organizadoras. Brasília; 2007.

41. Brasil. Ministério da Educação. Secretaria de Educação a Distância. Objetos de aprendizagem. Linux Educacional. [Internet]. [s.d.] [citado 2017 fev. 04]. Disponível em: http://webeduc.mec.gov.br/linuxeducacional/curso_le/modulo4.html

42. Machado LR, Maissiat J, Behar PA, Biazus MCV. Pedagogia, andragogia e gerontogogia: utilizando objetos de aprendizagem ao longo da vida. Práticas em Informática na Educação: Minicursos do Congresso Brasileiro de Informática na Educação. 2010;1(1):89-98.

43. Calil FC, Peres HHC, Zaima J, Tobase L. A produção científica de objetos de aprendizagem no ensino em enfermagem. J. Health Inform [Internet]. 2012 [citado 2016 dez. 05];04 (Número Especial - SIIENF 2012): 138-43. Disponível em: http://www.jhisbis.saude.ws/ojs-jhi/index.php/jhi-sbis/article/view/245/134.

44. Ribeiro RL, Masson VA, Hipólito MCV, Tobase L, Tomazini AS, Peres HHC. Learning object development for the Anatomy teaching in Nursing. Rev da Rede Enferm do Nord [Internet]. 2016 [cited 2017 Fev 16];17(6):866-73. Avaible from: http://www.revistarene.ufc.br/revista/index.php/revista/article/view/2442/pdf

45. Núcleo de Política e Gestão Tecnológica. Mapeamento da indústria brasileira e global de jogos digitais. GEDIGames. 2014.

46. Schuytema P. Projeto de jogos: uma abordagem prática. São Paulo, Cengage Learning, 2008.

47. Laprano MGG. Jogo de tabuleiro: cenário inovador na formação de professores de enfermagem. [Dissertação]. São Paulo: Escola de Enfermagem, Universidade de São Paulo; 2015.

48. Leite PS, Mendonça GV. Diretrizes para game design de jogos educacionais. SBC Proceedings of SBGames; 2013;132-41. 
49. Draganov PB, Sanna MC, Andrade AC, Neves VR. Andragogy in nursing: a literature review. Invest Educ Enferm. 2013;31(1):86-94.

50. Almeida DM. Construção e avaliação de aulas virtuais na formação de professores de enfermagem. [Dissertação]. São Paulo: Escola de Enfermagem, Universidade de São Paulo; 2013.

51. Aroldi JBC. Treinamento on-line sobre úlcera por pressão: aprendizagem, reação e o impacto no trabalho [Tese]. São Paulo: Escola de Enfermagem, Universidade de São Paulo; 2016.

52. São Paulo (Estado). Secretaria da Educação. Centro de Educação de Jovens e Adultos. Reflexões pedagógicas sobre o ensino e aprendizagem de pessoas jovens e adultas. Piconez SCB, autora. São Paulo:2013.

53. Knowles MS. The modern practice of adult education: from pedagogy to andragogy. $2^{\mathrm{a}}$ ed. New York: Press education; 1980.

54. Martins RMK. Pedagogia e andragogia na construção da educação de jovens e adultos. Rev Ed Pop. 2013;12(1):143-53.

55. Sousa ATO, Formiga NS, Oliveira SHS, Costa MML, Soares MJGO. Using the theory of meaningful learning in nursing education. Rev Bras Enferm [Internet]. 2015 [cited 2017 Jan 10];68(4):713-22. Available from: http://www.scielo.br/scielo.php?pid=S003471672015000400713\&script=sci_arttext\&tlng=en DOI: http://dx.doi.org/10.1590/00347167.2015680420i.

56. Prado C, Vaz DR, Almeida DM Afonso VLM. Andragogia: o desafio de ensinar e aprender com adultos na era contemporânea. In: Prado C, organizadora. Práticas pedagógicas em enfermagem: processo de reconstrução permanente. São Caetano do Sul: Difusão; 2013. p. 75-85.

57. Dable RA, Pawar BR, Gade JR, Anandan PM, Nazirkar GS, Karani JT. Student apathy for classroom learning and need of repositioning in present andragogy in Indian dental schools. BMC Med Educ [Internet]. 2012 [cited 2017 Mar 16];12(118). Available from: https://bmcmededuc.biomedcentral.com/articles/10.1186/1472-6920-12-118 DOI: 10.1186/1472-6920-12-118.

58. Draganoc PB, Sanna MC. Avaliação das competências dos professores de enfermagem para facilitar a aprendizagem de adultos. Cogitare Enferm. 2015;20(3):556-64.

59. Maciel JFSB, Vieira AMDP. A andragogia na educação corporativa: treinamento para a copa do mundo 2014. Rev Intersaberes. 2015;10 (21):676-91.

60. Macêdo MEC. Avaliação de treinamento à distância no contexto das ações de capacitação da rede de colaboração e aprendizagem em instituições federais de ensino. Salvador: Instituto de Psicologia, Universidade Federal da Bahia; 2011.

61. Salvador PTCO, Martins CCF, Alves KYA, Pereira MS, Santos VEB, Tourinho FSV. Tecnologia no ensino de enfermagem. Revista Baiana de Enfermagem. 2015;29(1):3341. 
62. Abio G. Andragogia e inclusão digital: algumas reflexões. Educação a distância e práticas educativas comunicacionais e interculturais. Revista EDaPECI. [Internet]. 2010 [citado 2015 jun.10];(6):31-49. Disponível em: http://www.edapeci-ufs.net/revista/ojs2.2.3/index.php/edapeci

63. Vilarinho LRG, Nunes LC. Avaliação da aprendizagem no ensino online. Em busca de novas práticas. In: Silva M, Santos E, organizadores. Avaliação da aprendizagem em educação online: fundamentos, interfaces e dispositivos, relato de experiências. São Paulo: Loyola; 2006. p. 109-21.

64. Pesce L, Brakling K. A avaliação do aprendizado em ambientes digitais de formação de educadores. Um olhar inicial. In: Silva M, Santos E, organizadores. Avaliação da aprendizagem em educação online: fundamentos, interfaces e dispositivos, relato de experiências. São Paulo: Loyola; 2006. p. 91-108.

65. Kenski VM, Oliveira GP, Clementino A. Avaliação em movimento: estratégias formativas em cursos online. In: Silva M, Santos E, organizadores. Avaliação da aprendizagem em educação online: fundamentos, interfaces e dispositivos, relato de experiências. São Paulo: Loyola; 2006. p. 79-89.

66. Santos N. Desafios da Web: como avaliar alunos online. In: Silva M, Santos E, organizadores. Avaliação da aprendizagem em educação online: fundamentos, interfaces e dispositivos, relato de experiências. São Paulo: Loyola; 2006. p. 245-65.

67. Gonçalves MIR. Avaliação no contexto educacional online. In: Silva M, Santos E, organizadores. Avaliação da aprendizagem em educação online: fundamentos, interfaces e dispositivos, relato de experiências. São Paulo: Loyola; 2006. p. 171-81.

68. Okada ALP, Almeida FJ. Avaliar é bom, avaliar faz bem. In: Silva M, Santos E, organizadores. Avaliação da aprendizagem em educação online: fundamentos, interfaces e dispositivos, relato de experiências. São Paulo: Loyola; 2006. p. 267-87.

69. Fiorentino LMR. Pesquisando ambientes de aprendizagem online. In: Silva M, Santos E, organizadores. Avaliação da aprendizagem em educação online: fundamentos, interfaces e dispositivos, relato de experiências. São Paulo: Loyola; 2006. p. 123-39.

70. Lima Junior AS, Alves LRG. Educação e contemporaneidade: novas aproximações sobre avaliação no ensino online. In: Silva M, Santos E, organizadores. Avaliação da aprendizagem em educação online: fundamentos, interfaces e dispositivos, relato de experiências. São Paulo: Loyola; 2006. p. 67-78.

71. Rocha HV, Otsuka JL, Freitas CEF, Ferreira TB. Avaliação online: o modelo de suporte tecnológico do porjeto telEDuc. In: Silva M, Santos E, organizadores. Avaliação da aprendizagem em educação online: fundamentos, interfaces e dispositivos, relato de experiências. São Paulo: Loyola; 2006. p. 347-68.

72. Brasil. Ministério da Educação; Programa das Nações Unidas para o Desenvolvimento. Marchiorato L. Melhorando o desempenho escolar: caderno de apoio à elaboração da proposta pedagógica da escola. [S.1.]; 2014.

73. Valadares J. A teoria da aprendizagem significativa como teoria construtivista. Aprendizagem Significativa em Revista. 2011;1(1):36-57. 
74. Nascimento MCM. Avaliação da aprendizagem: repercussões de modelos pedagógicos nas concepções docentes. [Dissertação]. Paraná: Universidade Estadual de Londrina. 2012.

75. Ausubel DP. Aquisição e retenção de conhecimentos: uma perspectiva cognitiva. Trad. Lígia Teopisto. Lisboa. Plátano Edições Técnicas. 2000;35.

76. Medeiros M. Bezerra EL. Contribuições das neurociências ao processo de alfabetização e letramento em uma prática do projeto alfabetizar com sucesso. Rev Bras Estud Pedagógicos [Internet]. 2015 [citado 2017 mar. 21];96(242):26-41. Disponível em: http://www.scielo.br/scielo.php?script=sci_arttext\&pid=S2176$66812015000100026 \&$ lang $=\mathrm{pt}$

77. Prado C. Tecnologias digitais no curso de licenciatura em enfermagem: uma inovação no processo ensino-aprendizagem.[tese livre-docência]. São Paulo: Escola de Enfermagem, Universidade de São Paulo; 2013.

78. Prado C, Vaz DR, Almeida DM. Aprendizagem significativa no contexto da enfermagem. In: Prado C, organizadora. Práticas pedagógicas em enfermagem: processo de reconstrução permanente. 1a. São Caetano do Sul; Difusão. 2013. p. 87-101.

79. Filatro A, Piconez SCB. Design instrucional contextualizado. In: Anais do 11o Congresso Internacional de Educação à Distância; 2004 set 7-10; Salvador [Internet]. 2004 [citado 2016 nov. 15]; Disponível em: http://www.abed.org.br/congresso2004/por/htm/049-TCB2.htm.

80. Heimann C. Capacitação pedagógica de docentes de enfermagem: desenvolvimento e avaliação de um curso a distância [Internet]. São Paulo: Escola de Enfermagem da Universidade de São Paulo; 2012. [citado 2016 nov. 29] Disponível em http://www.teses.usp.br/teses/disponiveis/7/7140/tde-11052012-105441/pt- br.php

81. Bremer C. Enhancing e-learning quality through the application of the AKUE procedure model. J Comput Assist Learn. 2012;28(1):15-26.

82. Alhawiti MMF. A proposed model for evaluating the quality of online programs and courses: the case of the university of Tabuk. Education Journal. 2014;3(2):57-70.

83. Clark D. Why Instructional System Design and ADDIE? [Internet]. 2016. [cited 2017 Jan 29]. Avaible from: http://www.nwlink.com/ donclark/hrd/sat1.html

84. Faria NGF. Fotografia digital de feridas: desenvolvimento e avaliação de curso online para enfermeiros. [Dissertação] São Paulo: Escola de Enfermagem, Universidade de São Paulo; 2010.

85. Filatro A. Planejamento, design, implementação e avaliação de programas de educação on-line. Esc de Saúde Pública do Paraná [Internet]. 2007 [citado 2017 jan. 11];1-17. Disponível em: http://www.escoladegoverno.pr.gov.br/arquivos/File/material_didatico_EaD/andrea_fila tro_apostila.pdf

86. Zerbini T, Abbad G. Impacto de treinamento no trabalho via internet. RAE- eletrônica. 2005;4(2):(Art.16). 
87. Sperandio DJ. A tecnologia computacional móvel na sistematização da assistência de enfermagem: avaliação de um software-protótipo [Internet]. Ribeirão Preto: Escola de Enfermagem, Universidade de São Paulo 2008 [citado 2017 jan. 11]. Disponível em: http://www.teses.usp.br/teses/disponiveis/22/22132/tde-11092008-165036/publico/

88. Associação Brasileira de Normas Técnicas. ABNT NBR ISO/IEC 14598-6:2004: engenharia de software: avaliação de produto. Parte 6: documentação de módulos de avaliação. Rio de Janeiro: ABNT; 2004.

89. Ozonias Júnior OB, Aguiar YPC, Tavares TA. Abordagens para Avaliação de Softwares Educativos e sua Coerência com os Modelos de Qualidade de Software.In: V Congresso Brasileiro de Informática na Educação (CBIE 2016) - Anais do XXVII Simpósio Brasileiro de Informática na Educação (SBIE 2016); 2016 out 24-27; Uberlândia [Internet]. Uberlândia. 2012. [citado 2016 dez. 30]. Disponível em: http://www.brie.org/pub/index.php/sbie/article/view/6707. DOI: 10.5753/cbie.sbie.2016.270

90. Análise de Softwares Educacionais. Educ Rev [Internet]. 1987 [citado 2017 fev. 17];6:4144. Disponível em: http://www.uel.br/seed/nte/analisedesoftwares.html

91. Pereira WS, Cardoso Filho RJ, Silva RST, Silva WRA, Dantas VF, Aguiar YPC. Validação de uma abordagem combinada para avaliação de software educativo: avanços e desafios. Revista Tecnologias na Educação [Internet].2016[citado 2017 fev. 17];16:119(Ed. Temática II). [Apresentando no Congresso Regional sobre Tecnologias na Educação - Ctrl+E; 2016 mai 23-25; Natal]. Disponível em: http://tecedu.pro.br/ano8numerovol16-edicao-tematica-ii/

92. Silva RST, Silva WRA, Cardoso Filho RJ, Pereira WS, Aguiar YPC, Dantas VF. Aplicação comparativa de diferentes abordagens de avaliação para o software educativo duolingo: a complexidade de escolher uma abordagem adequada. Revista Tecnologias na Educação [Internet].2016[citado 2017 fev. 17];16:1-17(Ed. Temática II). [Apresentando no Congresso Regional sobre Tecnologias na Educação - Ctrl+E; 2016 mai 23-25; Natal]. Disponível em: http://tecedu.pro.br/ano8-numerovol16-edicao-tematica-ii/

93. Rocha AR, Campos GHB. Avaliação da qualidade de software educacional. Em Aberto [Internet]. 1993 [citado 2015 nov. 29];(57). Disponível em ttp://www.rbep.inep.gov.br/index.php/emaberto/article/viewFile/845/757

94. Appolinario F. Metodologia da ciência: filosofia e prática da pesquisa. São Paulo: Pioneira; 2006.

95. Marconi MDA, Lakatos EM. Técnicas de pesquisa: planejamento e execução de pesquisas amostragens e técnicas de pesquisas, elaboração, análise e interpretação de dados. $3^{\text {a }}$ ed. São Paulo: Atlas; 1996.

96. Campos GHB, Martins I, Nunes BP. Instrumento para a avaliação da qualidade de objetos de aprendizagem [perspectiva do usuário]. Coordenação Central de Educação a Distância da Pontifícia Universidade Católica do Rio de Janeiro - CCEAD PUC-RIO [Internet] 2008. [citado 2016 jun. 20]. Versão 5.0. Disponível em: http://web.ccead.pucrio.br/condigital/portal/InstrAvaliacao.pdf. 
97. Ferraz APCM, Belhot RV. Taxonomia de Bloom: revisão teórica e apresentação das adequações do instrumento para definição de objetivos instrucionais. Gest. Prod; São Carlos. 2010; 17 (2): 421-31.

98. Wen CL. Teleducação em saúde. In: Prado C, Peres HHC, Leite MMJ, organizadoras. Tecnologia da informação e da comunicação em enfermagem. São Paulo: Atheneu; 2011. p. 127-37.

99. Bhanji F, Donoghue AJ, Wolff MS, Flores GE, Halamek LP, Berman JM et al. American Heart Association Guidelines Update for Cardiopulmonary Resuscitation and Emergency Cardiovascular Care 2015.. Part 14: Education: 2015 American Heart Association Guidelines Update for Cardiopulmonary Resuscitation and Emergency Cardiovascular Care. Circulation [Internet]. 2015 [cited 2015 Nov 29];132(18):S561-73. Available from: http://circ.ahajournals.org/content/132/18_suppl_2?etoc

100. Afonso V. Aulas virtuais no curso de licenciatura em enfermagem: os estudantes como autores [Dissertação]. São Paulo: Escola de Enfermagem, Universidade de São Paulo; 2014.

101. Zerbini T, Abbad GS, Mourão L, Coelho Junior FA, Alvim S, Loiola E. Transferência de treinamento e impacto do treinamento em profundidade. In: Abbad GS Mourão L, Meneses PPM, Zerbini T, Borges - Andrade JE, Vilas - Boas R, organizadores. Medidas de avaliação em treinamento, desenvolvimento e educação: ferramentas para gestão de pessoas. Porto Alegre: Artmed; 2012. p. 127-44.

102. Filatro AC. Learning design como fundamentação teórico-prática para o design instrucional contextualizado. [Tese] São Paulo: Faculdade de Educação, Universidade de São Paulo; 2008.

103. Tavares R. Construindo mapas conceituais. Ciências \& Cognição. 2007;12:72-85.

104. Messa VC. Utilização de ambientes virtuais de aprendizagem - AVAS: a busca por uma aprendizagem significativa. Revista Brasileira de Aprendizagem Aberta e a Distância [Internet]. 2010. [citado 2016 out. 29];09. Disponível em: http://www.abed.org.br/revistacientifica/revista_pdf_doc/2010/2010_2462010174147.p df

105. Zerbini T, Abbad G. Construção e validação de uma escala de transferência de treinamento. Psicologia, ciência e profissão. 2010; 30 (4): 684 -97

106. Campos GHB. Metodologia para avaliação da qualidade de software educacional. Diretrizes para desenvolvimento e usuários. [Tese]. Rio de Janeiro: Engenharia de Produção, Universidade do Rio de Janeiro;1994.

107. Galvão ECF. Aplicativo multimídia em plataforma móvel para o ensino da mensuração da pressão venosa central. [Dissertação]. São Paulo: Escola de Enfermagem, Universidade de São Paulo; 2012.

108. Bussotti EA, Leite MTM, Alves ACC, Cristensen K. Online training for health professionals in three regions of Brazil. Rev Bras Enferm [Internet] 2016 [cited 2017 Mar 16];69(5):981-5. Available from: http://www.scielo.br/pdf/reben/v69n5/en_0034-7167reben-69-05-0981.pdf 
109. Manta A. Guia de jornalismo da internet: o planejamento [Internet]. [citado 2017 fev. 17]. Recuperado de: http://www.facom.ufba.br/pesq/cyber/manta/Guia/cap05.html

110. Bittencourt IM, Bittencourt IG. Avaliação da aprendizagem nos cursos de saúde utilizando ferramentas online. In: V EPEAL - Pesquisa em Educação: desenvolvimento, ética e responsabilidade social. 2010 ago. 31 - set 03; Alagoas [Internet]. Alagoas: 2010 [citado 2017 fev. 03]. Disponível em: http://dmd2.webfactional.com/

111. Luckesi CC. Avaliação da aprendizagem escolar. 6ª ed. São Paulo: Cortez; 1997.

112. Palmer E, Devitt P. The assessment of a structured online formative assessment program: a randomised controlled trial. BMC Med Educ [Internet]. 2014;14(8). [cited 2016 Nov 29]. Available from: http://bmcmededuc.biomedcentral.com/articles/10.1186/14726920-14-8 DOI: 10.1186/1472-6920-14-8

113. Contreras-Espinosa RS, Eguia-Gómes JL, Hildebrand HR. Aprendizagem baseada em jogos digitais. SBC - Proceeding S [Internet]. 2013 [citado 2017 fev. 22];204-10. Disponível em: http://scholar.google.com/scholar?hl=en\&btnG=Search\&q=intitle:Aprendizagem+basea da+em+Jogos+Digitais\#1

114. Rodrigues RCV. Desenvolvimento de ambiente virtual de aprendizagem em enfermagem sobre ressuscitação cardiorrespiratória em neonatologia [Dissertação]. São Paulo: Escola de Enfermagem, Universidade de São Paulo; 2008.

115. Sasso GTMD, Souza ML. A simulação assistida por computador: a convergência no processo de educar-cuidar da enfermagem. Texto Context - Enferm [Internet]. 2006 [citado 2016 dez. 23];15(2):231-9. Disponível em: http://www.scielo.br/scielo.php?script=sci_arttext\&pid=S0104-07072006000200006. DOI: http://dx.doi.org/10.1590/S0104-07072006000200006 Texto contexto - enferm.

116. Brasil. Ministério da Educação. Resolução CNE/CES 3/2001 RESOLUÇÃO CNE/CES $\mathrm{N}^{\circ} 3$, de 7 de Novembro de 2001. Institui diretrizes curriculares do curso de graduação em enfermagem[Internet]. Brasília: Diário Oficial da União; 2001. [citado 2016 dez. 10]. Disponível em: http://portal.mec.gov.br/cne/arquivos/pdf/CES03.pdf

117. Brandão CFS, Collares CF, Marin HF. A simulação realística como ferramenta educacional para estudantes de medicina. Sci Med. 2014;24(2):187-192.

118. Georg C, Zary N. Web-based virtual patients in nursing education: Development and validation of theory-anchored design and activity models. J Med Internet Res. 2014;16(4):1-12.

119. Scorsolini-Comin F. Avaliação dos Processos de Ensino -Aprendizagem em Ações Educacionais Ofertadas a Distância. Temas psicol [Internet]. 2013 [citado 2017 jan. 29];21(2):335-46. Disponível em: http://dx.doi.org/10.9788/TP2013.2-03

120. Associação Brasileira de Normas Técnicas. ABNT NBR ISO/IEC 14598-1:2001. Tecnologia de informação. Avaliação de produto de software - Parte 1: Visão geral. Rio de Janeiro: ABNT; 2001. 
APÊNDICES 



\section{APÊNDICES}

\section{APÊNDICE A - Carta Convite Enviada aos Especialistas}

Prezado colega,

Eu, Edenir Aparecida Sartorelli Tomazini, sou responsável pela pesquisa "Curso On-line sobre Suporte Avançado à Vida em Parada Cardiorrespiratória para Enfermeiro", desenvolvida como Mestranda, vinculada ao Programa de Pós-Graduação em Gerenciamento em Enfermagem, na Escola de Enfermagem da Universidade de São Paulo, sob orientação da Prof. ${ }^{a}$ Dr. ${ }^{a}$ Heloisa Helena Ciqueto Peres.

Trata-se de curso totalmente on-line, organizado em nove unidades de aprendizagem que aborda aspectos teóricos sobre as intervenções de Suporte Avançado de Vida a serem realizadas no atendimento ao paciente adulto em parada cardiorrespiratória e é direcionado a enfermeiros envolvidos na assistência ao paciente nesta situação. Seu conteúdo foi desenvolvido por profissionais envolvidos na área de educação a distância e na assistência ao paciente crítico, com base nas diretrizes da American Heart Association e da Sociedade Brasileira de Cardiologia para o atendimento em parada cardiorrespiratória.

Atualmente, o curso está hospedado na Plataforma Moodle ${ }^{\circledR}$ do Grupo de Estudos e Pesquisas de Tecnologia da Informação nos Processos de Trabalho da Enfermagem (GEPETE).

Gostaríamos de convidá-lo para participar como avaliador do curso on-line. Para avaliar é necessário atender, pelo menos, um dos critérios:

- ser docente ou enfermeiro especialista em cardiologia ou emergência ou terapia intensiva adulto: ter experiência e / ou atuar no ensino nessas áreas de, no mínimo, dois anos; ou

- ser docente ou enfermeiro e ter experiência no ensino ou na pesquisa em educação on-line de, no mínimo, dois anos.

Para tanto, enviaremos link e senha de acesso ao ambiente virtual, bem como o link para o posterior preenchimento do formulário de avaliação. Este formulário é composto por uma breve seção de caracterização do avaliador e por 20 perguntas de múltipla escolha, com tempo estimado de preenchimento de 30 minutos e prazo de 15 dias para ser avaliado.

Pedimos que confirme sua disponibilidade em participar desta etapa do projeto na qualidade de especialista até 17 de novembro de 2016, para que possamos enviar o link do material a ser avaliado.

A pesquisa foi aprovada pelo Comitê de Ética em Pesquisa da Escola de Enfermagem da Universidade de São Paulo e se necessário, você poderá entrar em contato com o Comitê de Ética: E-mail: cepee@ usp.br. Telefone: (11) 3061-8858.

Desde já agradecemos e contamos com sua contribuição.

Atenciosamente, Edenir Aparecida Sartorelli Tomazini (edenirtomazini@usp.br)

Prof. ${ }^{a}$ Dr. ${ }^{a}$ Heloisa Helena Ciqueto Peres

Escola de Enfermagem da Universidade de São Paulo 


\section{APÊNDICE B - Termo de Consentimento Livre e Esclarecido - TCLE}

Eu, Edenir Aparecida Sartorelli Tomazini, mestranda do Programa de Pós-Graduação em Gerenciamento em Enfermagem da Escola de Enfermagem da Universidade de São Paulo, sob orientação da Prof. ${ }^{a}$ Dr. ${ }^{a}$ Heloisa Helena Ciqueto Peres, convido você a participar da pesquisa por mim desenvolvida e intitulada como "Curso On-line sobre Suporte Avançado de Vida em Parada Cardiorrespiratória para Enfermeiro". A pesquisa tem por objetivo desenvolver e avaliar o curso on-line sobre suporte avançado à vida em parada cardiorrespiratória de adultos para enfermeiros.

O benefício desta pesquisa consiste em elaborar o curso em reanimação cardiopulmonar no suporte avançado de vida utilizando o ambiente virtual de aprendizagem Moodle ${ }^{\circledR}$ com o objetivo de planejar, construir e avaliar o curso que possa contribuir para a capacitação de enfermeiros sobre o atendimento a parada cardiorrespiratória de adultos, visando à melhoria da qualidade do atendimento e a maior sobrevida aos pacientes.

Solicito seu consentimento para participação na avaliação do curso, com o objetivo de avaliar a qualidade e identificar possíveis falhas técnicas e limitações, para que sejam realizados os ajustes e as melhorias no produto final, bem como analisados as características e recursos facilitadores para a busca da qualidade do curso on-line para enfermeiros, para isso, será preciso acessar o curso on-line, no Ambiente Virtual de Aprendizagem (AVA) e responder o instrumento constituído de 20 questões, que poderá ser preenchido em aproximadamente 30 minutos, no prazo de 30 dias.

Os conteúdos da sua participação na avaliação serão utilizados para análise do curso online desenvolvido. Os resultados do estudo serão divulgados na instituição participante e em eventos e periódicos científicos.

Asseguramos o sigilo absoluto sobre sua identificação e informações obtidas. Esclarecemos que sua participação como avaliador do curso on-line é voluntária, e não há ônus ou custos previstos aos participantes.

Como riscos consideramos que poderá apresentar incômodo ou constrangimento ao responder o instrumento de avaliação e, caso ocorra, a qualquer momento você poderá deixar de participar da pesquisa e sua recusa não acarretará prejuízo de nenhuma ordem.

Os benefícios previstos pela sua participação no estudo será sua contribuição para o aperfeiçoamento do curso on-line, que no futuro, poderá colaborar na educação permanente dos enfermeiros que atuam no ambiente hospitalar nas situações de parada cardiorrespiratória em adultos. 
No AVA você terá acesso ao TCLE no seguinte endereço eletrônico “http://goo.gl/forms/aBfisEXzhthlSOkU2" e ao clicar no campo CONDORDO do link de acesso ao instrumento de avaliação, considera-se que você compreendeu as orientações e participará, livre e espontaneamente, desta pesquisa.

Esta pesquisa atende todas as especificações da Resolução 466, de 12 de dezembro de 2012, que aprova as diretrizes e normas regulamentadoras de pesquisas envolvendo seres humanos.

Se necessário, você poderá entrar em contato com a pesquisadora ou Comitê de Ética e Pesquisa (CEP) para obter esclarecimentos sobre o curso da pesquisa.

Os meios de contato com a pesquisadora responsável são: e-mail: sedeniraparecida@yahoo.com.br, celular: (11) 99561-1753, endereço: Av. Dr. Enéas de Carvalho Aguiar, 419 - Cerqueira Cesar - São Paulo/SP CEP - 05403-000 e com a orientadora Prof. ${ }^{a}$ Dr. ${ }^{a}$ Heloisa Helena Ciqueto Peres: email: hhcperes@ usp.br, telefone: (11) 3061-7552.

A pesquisa e sua aprovação ética podem ser consultadas a qualquer momento no CEP da EEUSP: situado na Av. Dr. Enéas de Carvalho Aguiar, 419 - Cerqueira Cesar - São Paulo/SP CEP - 05403-000. Telefone: (11) 3061-8858. E-mail: cepee@usp.br.

Agradecemos pela sua atenção e participação.

São Paulo, agosto de 2016.

Edenir Aparecida Sartorelli Tomazini

(Pesquisadora Responsável) 


\section{Matriz de Design Instrucional}

\begin{tabular}{|c|c|c|c|c|}
\hline Título & \multirow{2}{*}{\multicolumn{4}{|c|}{$\begin{array}{l}\text { Suporte Avançado de Vida no Atendimento do Adulto em Parada Cardiorrespiratória. } \\
\text { Sistematizar as etapas de Suporte Básico e Avançado de Vida durante a reanimação cardiopulmonar, respeitando os aspectos de segurança, de } \\
\text { ética e de humanização na assistência. }\end{array}$}} \\
\hline Objetivo & & & & \\
\hline $\begin{array}{l}\text { Tema das } \\
\text { Unidades de } \\
\text { Aprendizagem }\end{array}$ & Objetivos & Conteúdos & Ferramentas / Estratégias & Avaliação \\
\hline $\begin{array}{c}\text { Avaliação } \\
\text { diagnóstica* }\end{array}$ & $\begin{array}{l}\text { - Identificar os conhecimentos } \\
\text { prévios acerca do tema. } \\
\text { - Identificar as necessidades de } \\
\text { aprendizagem acerca do tema. }\end{array}$ & - Suporte Avançado de Vida & - Objeto de aprendizagem & $\begin{array}{l}\text { - Questões de } \\
\text { múltipla escolha }\end{array}$ \\
\hline $\begin{array}{l}\text { Revisão do } \\
\text { Suporte Básico de } \\
\text { Vida }\end{array}$ & $\begin{array}{l}\text { - Identificar os sinais indicativos } \\
\text { de PCR; } \\
\text { - Estabelecer as manobras de } \\
\text { RCP, segundo o algoritmo de } \\
\text { SBV para o atendimento em } \\
\text { PCR, considerando os princípios } \\
\text { de segurança, de ética e de } \\
\text { humanização. }\end{array}$ & $\begin{array}{l}\text { - Conceitos; } \\
\text { - Aspectos de biossegurança; } \\
\text { - Manobras de SBV (RCP e uso do } \\
\text { DEA); } \\
\text { - Carrinho de emergência; } \\
\text { - Trabalho em equipe; } \\
\text { - Times de resposta rápida; } \\
\text { - Registro da PCR. }\end{array}$ & $\begin{array}{l}\text { Leitura de texto: recurso Lição do Moodle }{ }^{\circledR} \\
\text { Vídeos: } \\
\text { - Inserção da cânula orofaríngea; } \\
\text { - Ventilação com bolsa-válvula-máscara; } \\
\text { - Uso do DEA; } \\
\text { - Suporte básico de vida (RCP e uso do DEA). } \\
\text { Material complementar: } \\
\text { - Infográfico sobre SBV; } \\
\text { - Artigos científicos; } \\
\text { - Links para recursos externos disponíveis na } \\
\text { web. }\end{array}$ & $\begin{array}{l}\text { - Exercícios } \\
\text { interativos do tipo } \\
\text { quizzes; } \\
\text { - Jogo educacional }\end{array}$ \\
\hline $\begin{array}{c}\text { Monitorização } \\
\text { Cardíaca }\end{array}$ & $\begin{array}{l}\text { - Definir os passos da } \\
\text { monitorização cardíaca com o } \\
\text { uso de eletrodos ou pás } \\
\text { manuais; } \\
\text { - Descrever o posicionamento } \\
\text { adequado das pás manuais do } \\
\text { desfibrilador ou das pás } \\
\text { autoadesivas de monitorização } \\
\text { /desfibrilação. }\end{array}$ & $\begin{array}{l}\text { - Conceitos e finalidades; } \\
\text { - Tipos de equipamentos; } \\
\text { - Cuidados na Monitorização } \\
\text { Cardíaca }\end{array}$ & $\begin{array}{l}\text { Leitura de texto: recurso Lição do Moodle® } \\
\text { Vídeos: } \\
\text { - Uso do DEA; } \\
\text { - Homem virtual: ECG. } \\
\text { Material complementar: } \\
\text { - Artigos científicos; } \\
\text { - Links para recursos externos disponíveis na } \\
\text { web. }\end{array}$ & $\begin{array}{l}\text { - Exercícios } \\
\text { interativos do tipo } \\
\text { quizzes; } \\
\text { - Jogo educacional }\end{array}$ \\
\hline
\end{tabular}




\begin{tabular}{|c|c|c|c|c|}
\hline $\begin{array}{l}\text { Análise do Ritmo } \\
\text { Cardíaco }\end{array}$ & $\begin{array}{l}\text { - Distinguir os ritmos cardíacos } \\
\text { associados à PCR e associar a } \\
\text { abordagem terapêutica } \\
\text { específica; } \\
\text { - Listar os três passos para } \\
\text { realização do protocolo da linha } \\
\text { reta. }\end{array}$ & $\begin{array}{l}\text { - Tipos de ritmos cardíacos; } \\
\text { - Características dos ritmos } \\
\text { chocáveis e não chocáveis. }\end{array}$ & $\begin{array}{l}\text { Leitura de texto: recurso Lição do Moodle®. } \\
\text { Vídeo: } \\
\text { - Homem virtual: ECG. } \\
\text { Material complementar: } \\
\text { - Artigos científicos; } \\
\text { - Links para recursos externos disponíveis na } \\
\text { web. }\end{array}$ & $\begin{array}{l}\text { - Exercícios } \\
\text { interativos do tipo } \\
\text { quizzes; } \\
\text { - Jogo educacional }\end{array}$ \\
\hline Desfibrilação & $\begin{array}{l}\text { - Diferenciar as especificidades } \\
\text { técnicas e do manejo do } \\
\text { desfibrilador manual e do } \\
\text { desfibrilador externo } \\
\text { automático; } \\
\text { - Descrever o procedimento de } \\
\text { desfibrilação; } \\
\text { - Relacionar os cuidados a serem } \\
\text { tomados pela equipe em relação } \\
\text { ao procedimento de } \\
\text { desfibrilação. }\end{array}$ & $\begin{array}{l}\text { - Conceito; } \\
\text {-Tipos de desfibriladores; } \\
\text { - Cuidados na desfibrilação. }\end{array}$ & $\begin{array}{l}\text { Leitura de texto: recurso Lição do Moodle®. } \\
\text { Vídeo: } \\
\text { - Uso do DEA. } \\
\text { Material complementar: } \\
\text { - Artigos científicos; } \\
\text { - Links para recursos externos disponíveis na } \\
\text { web. }\end{array}$ & $\begin{array}{l}\text { - Exercícios } \\
\text { interativos do tipo } \\
\text { quizzes; } \\
\text { - Jogo educacional }\end{array}$ \\
\hline $\begin{array}{c}\text { Acesso } \\
\text { Intravascular }\end{array}$ & $\begin{array}{l}\text { - Indicar as vias de } \\
\text { administração de medicamentos } \\
\text { utilizadas na PCR; } \\
\text { - Estabelecer os locais } \\
\text { prioritários e alternativos para } \\
\text { obtenção de acesso venoso e } \\
\text { intraósseo. }\end{array}$ & $\begin{array}{l}\text { - Vias de acesso intravascular; } \\
\text { - Locais indicados para punção } \\
\text { venosa e intraóssea. }\end{array}$ & $\begin{array}{l}\text { Leitura de texto: recurso Lição do Moodle®. } \\
\text { Vídeo sobre: } \\
\text { - Uso do BIG. } \\
\text { Material complementar: } \\
\text { - Artigos científicos; } \\
\text { - Links para recursos externos disponíveis na } \\
\text { web. }\end{array}$ & $\begin{array}{l}\text { - Exercícios } \\
\text { interativos do tipo } \\
\text { quizzes; } \\
\text { - Jogo educacional }\end{array}$ \\
\hline $\begin{array}{c}\text { Medicamentos } \\
\text { Recomendados na } \\
\text { PCR }\end{array}$ & $\begin{array}{l}\text { - Relacionar os principais } \\
\text { medicamentos utilizados na } \\
\text { PCR quanto à indicação, ao } \\
\text { mecanismo de ação, à dosagem, } \\
\text { à via de administração e aos } \\
\text { cuidados no preparo e na } \\
\text { administração durante a PCR. }\end{array}$ & $\begin{array}{l}\text { - Medicamentos recomendados na } \\
\text { PCR e suas especificidades; } \\
\text { - Cuidados no preparo e na } \\
\text { administração de medicamentos } \\
\text { durante a PCR. }\end{array}$ & $\begin{array}{l}\text { Leitura de texto: recurso Lição do Moodle®. } \\
\text { Material complementar: } \\
\text { - Artigos científicos; } \\
\text { - Links para recursos externos disponíveis na } \\
\text { web. }\end{array}$ & $\begin{array}{l}\text { - Exercícios } \\
\text { interativos do tipo } \\
\text { quizzes; } \\
\text { - Jogo educacional }\end{array}$ \\
\hline
\end{tabular}




\begin{tabular}{|c|c|c|c|c|}
\hline $\begin{array}{l}\text { Manejo de Via } \\
\text { Aérea Avançada }\end{array}$ & $\begin{array}{l}\text { - Selecionar os dispositivos de } \\
\text { via aérea avançada quanto à } \\
\text { modalidade, indicações, } \\
\text { contraindicações, vantagens, } \\
\text { desvantagens e técnica a ser } \\
\text { utilizada; } \\
\text { - Distinguir as diferenças na } \\
\text { assistência ventilatória antes e } \\
\text { depois do estabelecimento da } \\
\text { via aérea avançada. }\end{array}$ & $\begin{array}{l}\text { - Conceitos e finalidades dos } \\
\text { dispositivos de via aérea; } \\
\text { - Tipos de dispositivos; } \\
\text { - Materiais necessários para manejo } \\
\text { de vias aéreas; } \\
\text { - Técnica de inserção dos } \\
\text { dispositivos; } \\
\text { - Manejo de vias aéreas em parada } \\
\text { respiratória. }\end{array}$ & $\begin{array}{l}\text { Leitura de texto: recurso Lição do Moodle }{ }^{\circledR} \text {. } \\
\text { Vídeos: } \\
\text { - Ventilação com bolsa-válvula-máscara; } \\
\text { - Manejo de máscara laríngea; } \\
\text {-Intubação orotraqueal. } \\
\text { Material complementar: } \\
\text { - Artigos científicos; } \\
\text { - Links para recursos externos disponíveis na } \\
\text { web. }\end{array}$ & $\begin{array}{l}\text { - Exercícios } \\
\text { interativos do tipo } \\
\text { quizzes; } \\
\text { - Jogo educacional }\end{array}$ \\
\hline $\begin{array}{c}\text { Causas Reversíveis } \\
\text { de PCR }\end{array}$ & $\begin{array}{l}\text { - Relacionar as causas } \\
\text { reversíveis de PCR; } \\
\text { - Estabelecer o tratamento } \\
\text { específico associado às causas } \\
\text { reversíveis de PCR. }\end{array}$ & $\begin{array}{l}\text { - Descrição das causas reversíveis; } \\
\text { - Causas mais frequente; } \\
\text { - Associação das causas com o } \\
\text { tratamento específico. }\end{array}$ & $\begin{array}{l}\text { Leitura de texto: recurso Lição do Moodle®. } \\
\text { Material complementar: } \\
\text { - Artigos científicos; } \\
\text { - Links para recursos externos disponíveis na } \\
\text { web. }\end{array}$ & $\begin{array}{l}\text { - Exercícios } \\
\text { interativos do tipo } \\
\text { quizzes; } \\
\text { - Jogo educacional. }\end{array}$ \\
\hline $\begin{array}{l}\text { Cuidados pós - } \\
\text { PCR }\end{array}$ & $\begin{array}{l}\text { - Determinar os cuidados } \\
\text { imediatos pós - PCR; } \\
\text { - Valorizar a importância dos } \\
\text { cuidados pós- PCR, respeitando } \\
\text { os aspectos de ética e de } \\
\text { humanização. }\end{array}$ & $\begin{array}{l}\text { - Descrição dos cuidados pós-PCR; } \\
\text { - Decisâo de interromper ou não a } \\
\text { RCP. } \\
\text { - Reflexão sobre princípios éticos e } \\
\text { humanos do cuidar. }\end{array}$ & $\begin{array}{l}\text { Leitura de texto: recurso Lição do Moodle®. } \\
\text { Material complementar: } \\
\text { - Artigos científicos; } \\
\text { - Links para recursos externos disponíveis na } \\
\text { web. }\end{array}$ & $\begin{array}{l}\text { - Exercícios } \\
\text { interativos do tipo } \\
\text { quizzes; } \\
\text { - Jogo educacional. }\end{array}$ \\
\hline Avaliação Final* & $\begin{array}{l}\text { - Avaliar a aprendizagem e } \\
\text { transferência do conhecimento }\end{array}$ & - Suporte Avançado de Vida & $\begin{array}{l}\text { - Atendimento ao paciente em PCR (simulação } \\
\text { produzida no software Articulate Storyline }{ }^{\circledR} \text { ) }\end{array}$ & $\begin{array}{l}\text { - Ações adotadas no } \\
\text { atendimento aos } \\
\text { pacientes simulados. }\end{array}$ \\
\hline
\end{tabular}

* Embora as avaliações diagnóstica e final não se constituam como unidades de aprendizagem foram aqui incluídas para facilitar a compreensão da estrutura geral do curso. 
ANEXOS 



\section{ANEXOS}

\section{ANEXO A: Instrumento para Avaliação da Qualidade do Curso On-line}

\section{Instruções para avaliação e preenchimento do instrumento de avaliação}

Em cada página, segue a descrição dos aspectos a serem avaliados no curso, a escala de avaliação e uma caixa de comentários. Para o preenchimento, analise cada critério e indique um dos itens da escala abaixo:

\section{Métrica $0($ ) $0,25($ ) $0,5($ ) $0,75($ ) $1($ ) NA ( )}

- Os valores variam entre $0-0,25-0,5-0,75-1$, onde 0 representa a avaliação mais negativa do critério e 1 a mais positiva.

- Assinale na escala, o valor que lhe parece melhor representar o grau que o critério foi atingido.

- Ao considerar que o item não se aplica ao critério avaliado, assinale NA.

- Utilize o campo "Comentários" para expressar suas impressões e sugestões. Por favor, caso assinale valoress: 0 ou 0,25 ou 0,5 , justifique.

\section{Navegação Livre}

Permite a navegação livre, isto é, permite o controle da sequência de uso durante a utilização do software. Favorece a autonomia do usuário no uso dos comandos.

Métrica $0(\quad) \quad 0,25(\quad) \quad 0,5(\quad) \quad 0,75(\quad) \quad 1(\quad) \quad N A(\quad)$

Comentários:

\section{Clareza das Informações}

Enfoca apenas um conceito básico. É interessante que cada conceito seja abordado de maneira clara e, de preferência, em uma única janela, facilitando o entendimento das informações.

Métrica $0(\quad) \quad 0,25(\quad) \quad 0,5(\quad) \quad 0,75(\quad) \quad 1(\quad) \quad N A(\quad)$

Comentários: 


\section{Facilidade de Localização das Informações}

Possui mecanismos que facilitam a localização da informação. É importante que o usuário tenha informação sobre o que existe no curso on-line e como ele está organizado. Para isto é preciso que existam mecanismos que apresentem formas de localização tais como mapas globais, rota de aprendizagem, menu, glossário e outras guias.

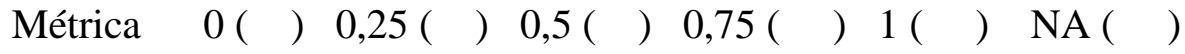

Comentários:

\section{Pertinência}

O conteúdo é apresentado de forma lógica. As formas de interação e navegação são rapidamente compreendidas.

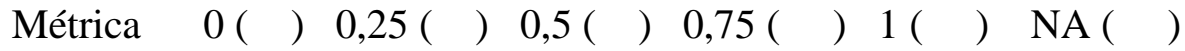

Comentários:

\section{Contextualização}

O conteúdo está adequado e coerente com a área e o nível de ensinos propostos.

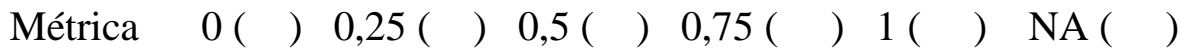

Comentários:

\section{Correção de Conteúdo}

Avalia o rigor científico dos conhecimentos transmitidos.

Métrica $0(\quad) \quad 0,25(\quad) \quad 0,5(\quad) \quad 0,75(\quad) \quad 1(\quad)$ NA ( )

Comentários: 


\section{Múltiplas Janelas}

Abre várias janelas simultaneamente, se necessário. Isto não é uma regra, pois a abertura de múltiplas janelas sobrepostas também pode confundir o leitor. Contudo, em certas situações torna-se interessante apresentar informações parcialmente sobrepostas.

Métrica $0(\quad) \quad 0,25(\quad) \quad 0,5(\quad) \quad 0,75(\quad) \quad 1(\quad$ NA $(\quad)$

Comentários:

\section{Facilidade de Aprendizagem na Interação}

Permite compreender rapidamente a interação no software e sua navegação deve ser de fácil entendimento pelo usuário.

Métrica $0(\quad) \quad 0,25(\quad) \quad 0,5(\quad) \quad 0,75(\quad) \quad 1(\quad) \quad N A(\quad)$

Comentários:

\section{Eficiência de Utilização}

A navegação é simples, isto é, todas as informações e comandos apresentados são relevantes para a utilização no treinamento.

Métrica $0(\quad) \quad 0,25(\quad) \quad 0,5(\quad) \quad 0,75(\quad) \quad 1(\quad)$ NA ( )

Comentários:

\section{Facilidade de Retorno.}

Retorno fácil a localizações anteriores. Muitas vezes, durante a navegação pode ocorrer o caso onde o leitor decide seguir ligações que o conduzam a informações inesperadas e/ou indesejadas. Neste caso, o software deve possibilitar o retorno fácil.

Métrica $0(\quad) \quad 0,25(\quad) \quad 0,5(\quad) \quad 0,75(\quad) \quad 1(\quad) \quad N A(\quad)$

Comentários: 


\section{Ergonomia}

Manutenção da interação e da apresentação de forma uniforme em todas as telas. A uniformidade dos recursos utilizados na navegação (ex.: botões e ícones localizados sempre na mesma posição) permite ao usuário familiarização de forma mais eficiente.

Métrica $0(\quad) \quad 0,25(\quad) \quad 0,5(\quad) \quad 0,75(\quad) \quad 1(\quad)$ NA $(\quad)$

Comentários:

\section{Estética}

O objeto possui padrões de interface adequados ao conteúdo.

Métrica $0(\quad) \quad 0,25(\quad) \quad 0,5(\quad) \quad 0,75(\quad) \quad 1(\quad) \quad N A(\quad)$

Comentários:

\section{Uso de Marcas Especiais}

Utilização de marcas especiais como cores, molduras e outras para facilitar o reconhecimento do contexto em que se encontra. É interessante que, ao mudar de contexto durante a navegação pelo treinamento, o leitor receba indicações visuais a respeito do ponto em que se encontra, facilitando a sua orientação.

Métrica $0(\quad) \quad 0,25(\quad) \quad 0,5(\quad) \quad 0,75(\quad) \quad 1($ ) $\mathrm{NA}(\quad)$

Comentários:

\section{Utilização de Recursos Audiovisuais}

Apresenta recursos audiovisuais de maneira adequada.

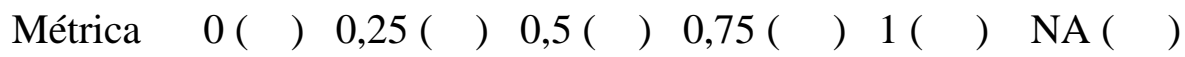

Comentários: 


\section{Referências}

Apresentação das fontes de seu conteúdo e das informações de seu autor.

Métrica $0(\quad) \quad 0,25(\quad) \quad 0,5(\quad) \quad 0,75(\quad) \quad 1(\quad$ NA $($ )

Comentários:

\section{Interatividade}

Interação com o software. Há evidências de que o aluno aprende mais quando participa ativamente do processo de aprendizado, e não fica apenas passivamente recebendo informações.

Métrica $0(\quad) \quad 0,25(\quad) \quad 0,5(\quad) \quad 0,75(\quad) \quad 1(\quad)$ NA ( )

Comentários:

\section{Gestão de Erros}

Avalia os mecanismos que permitem evitar ou reduzir a ocorrência de erros, e quando eles ocorrem, estes mecanismos devem favorecer a sua correção. Inclui proteção contra erros, qualidade das mensagens de erro e correção dos erros e reversão fácil das ações.

Métrica $0(\quad) \quad 0,25(\quad) \quad 0,5(\quad) \quad 0,75(\quad) \quad 1(\quad) \quad \mathrm{NA}(\quad)$

Comentários:

\section{Ajuda aos Usuários}

Avalia a disponibilidade de auxílio. Há recursos de auxílio ao usuário.

Métrica $0(\quad) \quad 0,25(\quad) \quad 0,5(\quad) \quad 0,75(\quad) \quad 1(\quad) \quad N A(\quad)$

Comentários: 


\section{Qualidade da Informação}

Avalia conteúdos corretos, fontes fidedignas, vocabulário adequado ao público, carga informacional (quantidade de informações) compatível.

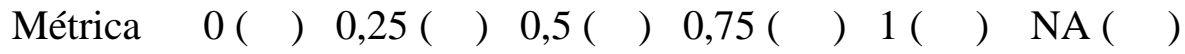

Comentários:

\section{Portabilidade}

Funcionamento adequado em diferentes browsers.

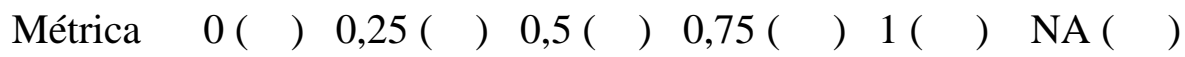

Comentários: 


\section{ANEXO B - Parecer Consubstanciado do Comitê de Ética e Pesquisa da Escola de Enfermagem da USP - EEUSP}

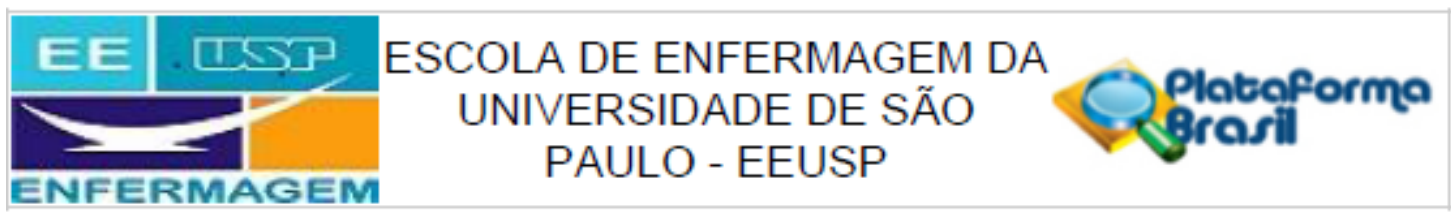

\section{PARECER CONSUBSTANCIADO DO CEP}

\section{DADOS DO PROJETO DE PESQUISA}

Título da Pesquisa: Treinamento Online sobre Suporte Avançado à Vida em Parada Cardiorrespiratória para Enfermeiros

Pesquisador: Edenir Aparecida Sartorelli Tomazini

Área Temática:

Versão: 3

CAAE: 54831516.5 .0000 .5392

Instituição Proponente: Escola de Enfermagem da Universidade de São Paulo - EEUSP

Patrocinador Principal: Financiamento Próprio

DADOS DO PARECER

Número do Parecer: 1.667.269

Apresentação do Projeto:

Trata-se da segunda versão do projeto de mestrado de Edenir Aparecida Sartorelli Tomazini, orientado pela Profa Dra Heloisa Helena Ciqueto Peres, denominado "Treinamento Online sobre Suporte Avançado à Vida em Parada Cardiorrespiratória para Enfermeiro", a ser realizado no Programa de Pós-Graduação em Gerenciamento em Enfermagem da Escola de Enfermagem da Universidade de São Paulo

Objetivo da Pesquisa:

Tem como objetivo primário: "Desenvolver e avaliar um treinamento online de suporte avançado à vida em parada cardiorrespiratória de adultos para enfermeiros" e como objetivo secundário "Construir um treinamento sobre parada cardiorrespiratória utilizando o ambiente virtual de aprendizagem Moodle e avaliar o treinamento na perspectiva de especialistas".

Avaliação dos Riscos e Beneficios:

Apresenta como risco que "que poderá apresentar incômodo ou constrangimento ao responder o instrumento de avaliação, caso ocorra, será indicada a imediata suspensão da participação no estudo ou outro acompanhamento, se necessário" e como Benefícios "será sua contribuição para o aperfeiçoamento do treinamento online, que no futuro, poderá colaborar na educação permanente dos enfermeiros que atuam no ambiente hospitalar nas situações de parada cardiorrespiratória em

Endereço: Av. Dr Enéas de Carvalho Aguiar, 418

Bairro: Cerqueira Cesar CEP: $05.403-000$

UF: SP Município: SAO PAULO

Telefone: (11)3061-8858

E-mail: cepee@usp.br 


\section{EE TSP ESCOLA DE ENFERMAGEM DA

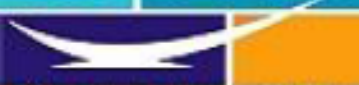 \\ ENFERMAGEM \\ UNIVERSIDADE DE SÃO QRrosilorma PAULO - EEUSP}

Contnuaçăo do Parecer. 1.667.269

adultos"

Comentários e Considerações sobre a Pesquisa:

A pesquisadora incorporou ao projeto a formulário de avaliação, bem como inseriu o link no termo no TCLE.

Fez os ajustes requerido no TCLE

Considerações sobre os Termos de apresentação obrigatória:

TCLE apresentado e ajustado. Orçamento e cronogramas adequeados

Recomendações:

não

Conclusões ou Pendências e Lista de Inadequações:

Os ajustes necessários foram promovidos

Consideraçôes Finais a critério do CEP:

Este CEP informa a necessidade de registro dos resultados parciais e finais na Plataforma Brasil.

Esta aprovação não substitui a autorização da instituição coparticipante, antes do início da coleta de dados.

Este parecer foi elaborado baseado nos documentos abaixo relacionados:

\begin{tabular}{|c|c|c|c|c|}
\hline Tipo Documento & Arquivo & Postagem & Autor & Situação \\
\hline $\begin{array}{l}\text { Informações Básicas } \\
\text { do Projeto }\end{array}$ & $\begin{array}{l}\text { PB_INFORMAÇŌES_BASICAS_DO_P } \\
\text { ROJETO_691145.pdf }\end{array}$ & $\begin{array}{c}16 / 07 / 2016 \\
15: 14: 04 \\
\end{array}$ & & Aceito \\
\hline $\begin{array}{l}\text { Projeto Detalhado / } \\
\text { Brochura } \\
\text { Investigador }\end{array}$ & ProjetocompletoEQEdenir160716.docx & $\begin{array}{c}16 / 07 / 2016 \\
15: 12: 36\end{array}$ & $\begin{array}{l}\text { Edenir Aparecida } \\
\text { Sartorelli Tomazini }\end{array}$ & Aceito \\
\hline $\begin{array}{l}\text { TCLE / Termos de } \\
\text { Assentimento / } \\
\text { Justificativa de } \\
\text { Ausência }\end{array}$ & TCLE160716.pdf & $\begin{array}{c}16 / 07 / 2016 \\
15: 11: 39\end{array}$ & $\begin{array}{l}\text { Edenir Aparecida } \\
\text { Sartorelli Tomazini }\end{array}$ & Aceito \\
\hline Outros & $\begin{array}{l}\text { CartasobreParecerConsubstanciadodoC } \\
\text { EP.pdf }\end{array}$ & $\begin{array}{c}15 / 07 / 2016 \\
16: 01: 09 \\
\end{array}$ & $\begin{array}{l}\text { Edenir Aparecida } \\
\text { Sartorelli Tomazini }\end{array}$ & Aceito \\
\hline Folha de Rosto & Folhaderosto.pdf & $\begin{array}{c}04 / 04 / 2016 \\
17: 57: 29 \\
\end{array}$ & $\begin{array}{l}\text { Edenir Aparecida } \\
\text { Sartorelli Tomazini }\end{array}$ & Aceito \\
\hline Orçamento & Orcamento.pdf & $\begin{array}{c}03 / 04 / 2016 \\
23: 54: 04 \\
\end{array}$ & $\begin{array}{l}\text { Edenir Aparecida } \\
\text { Sartorelli Tomazini }\end{array}$ & Aceito \\
\hline Cronograma & Cronograma.pdf & $\begin{array}{c}03 / 04 / 2016 \\
23: 52: 41 \\
\end{array}$ & $\begin{array}{l}\text { Edenir Aparecida } \\
\text { Sartorelli Tomazini }\end{array}$ & Aceito \\
\hline
\end{tabular}

Endereço: Av. Dr Enéas de Carvalho Aguiar, 419

Bairro: Cerqueira Cesar

UF: SP Município: SAO PAULO

CEP: $05.403-000$

Telefone: (11)3061-8858

E-mail: cepee@usp.br 


\section{ESCOLA DE ENFERMAGEM DA
UNIVERSIDADE DE SÃO
PAULO - EEUSP Plotoforma}

Continuação do Parecer: 1.667.269

Situação do Parecer:

Aprovado

Necessita Apreciação da CONEP:

Não

SAO PAULO, 03 de Agosto de 2016

Assinado por:
Marcelo José dos Santos

(Coordenador)

Endereço: Av. Dr Enéas de Carvalho Aguiar, 419

Bairro: Cerqueira Cesar

CEP: $05.403-000$

UF: SP

Município: SAO PAULO

Telefone: (11)3061-8858

E-mail: cepee@usp.br

Página 03 de 03 